\title{
Hydrologic Evaluation for Model Validation Wells MV-1, MV-2, and MV-3 Near the Project Shoal Area
}

\author{
Prepared by \\ Brad Lyles, Phil Oberlander, David Gillespie, Dee Donithan, \\ Jenny Chapman, and John Healey
}

submitted to

Nevada Site Office

National Nuclear Security Administration

U.S. Department of Energy

Las Vegas, Nevada

September 2006

Publication No. 45220 
Reference herein to any specific commercial product, process, or service by trade name, trademark, manufacturer, or otherwise, does not necessarily constitute or imply its endorsement, recommendation, or favoring by the United States Government or any agency thereof or its contractors or subcontractors.

Available for sale to the public from:

U.S. Department of Commerce

National Technical Information Service

5285 Port Royal Road S/D

Springfield, VA 22161-0002

Phone: 800.553.6847

Fax: 703.605.6900

Email: orders@ntis.gov

Online ordering: http://www.ntis.gov/ordering.htm

Available electronically at http://www.osti.gov/bridge

Available for a processing fee to the U.S. Department of Energy and its contractors, in paper, from:

U.S. Department of Energy

Office of Scientific and Technical Information

P.O. Box 62

Oak Ridge, TN 37831-0062

Phone: 865.576 .8401

Fax: 865.576.5728

Email: reports@adonis.osti.gov 


\title{
Hydrologic Evaluation for Model Validation Wells MV-1, MV-2, and MV-3 Near the Project Shoal Area
}

\author{
Prepared by \\ Brad Lyles, Phil Oberlander, David Gillespie, Dee Donithan, \\ Jenny Chapman, and John Healey \\ Division of Hydrologic Sciences \\ Desert Research Institute \\ Nevada System of Higher Education
}

Publication No. 45220

\author{
Submitted to \\ Nevada Site Office \\ National Nuclear Security Administration \\ U.S. Department of Energy \\ Las Vegas, Nevada
}

September 2006

The work upon which this report is based was supported by the U.S. Department of Energy under Contract \#DE-AC52-00NV13609. Approved for public release; further dissemination unlimited. 
THIS PAGE INTENTIONALLY LEFT BLANK 


\section{ABSTRACT}

In 2006, a drilling campaign was conducted at the Project Shoal Area (PSA) to provide information for model validation, emplace long-term monitoring wells, and develop baseline geochemistry for long term hydrologic monitoring. Water levels were monitored in the vicinity of the drilling, in the existing wells $\mathrm{HC}-1$ and $\mathrm{HC}-6$, as well as in the newly drilled wells, MV-1, MV-2 and MV-3 and their associated piezometers. Periodic water level measurements were also made in existing wells $\mathrm{HC}-2, \mathrm{HC}-3, \mathrm{HC}-4, \mathrm{HC}-5$ and HC-7.

A lithium bromide chemical tracer was added to drilling fluids during the installation of the monitoring and validation (MV) wells and piezometers. The zones of interest were the fractured, jointed and faulted horizons within a granitic body. These horizons generally have moderate hydraulic conductivities. As a result, the wells and their shallower piezometers required strenuous purging and development to remove introduced drilling fluids as evidenced by bromide concentrations.

After airlift and surging well development procedures, the wells were pumped continuously until the bromide concentration was less then 1 milligram per liter $(\mathrm{mg} / \mathrm{L})$.

Water quality samples were collected after the well development was completed. Tritium scans were preformed before other analyses to ensure the absence of high levels of radioactivity. Tritium levels were less than 2,000 pico-curies per liter. Samples were also analyzed for carbon-14 and iodine-129, stable isotopes of oxygen and hydrogen, as well as major cations and anions. Aquifer tests were performed in each MV well after the bromide concentration fell below acceptable levels. Water level data from the aquifer tests were used to compute aquifer hydraulic conductivity and transmissivity.

\section{ACKNOWLEDGMENTS}

The complex operation of drilling and completion of the MV wells at PSA was successful due to the skill and dedication of many people. The authors would like to particularly acknowledge contributions to the data included in this report made by Tim Echelard, Richard Findlay, Greg Studley, and Robert Dickerson, all of Stoller-Navarro Joint Venture. Karl Pohlmann, of DRI, provided an invaluable bridge between the Shoal groundwater model and the activities in the field. The authors are grateful for the opportunity to work with these people in furthering the understanding of PSA hydrogeology. 
THIS PAGE INTENTIONALLY LEFT BLANK 


\section{CONTENTS}

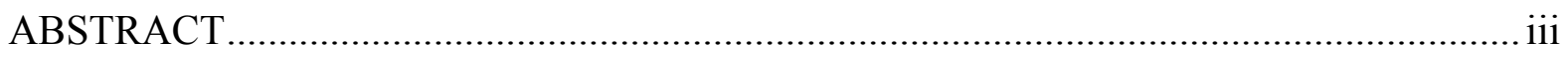

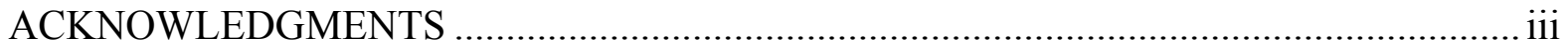

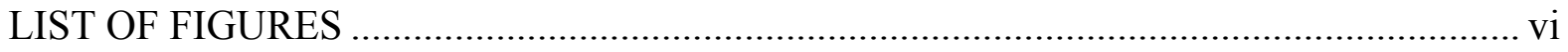

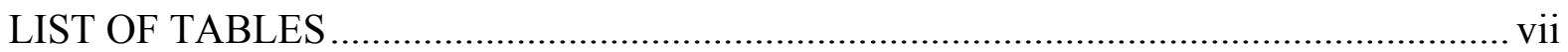

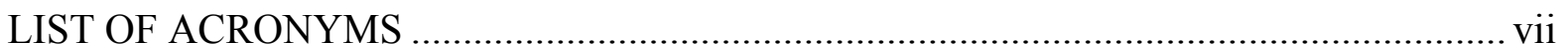

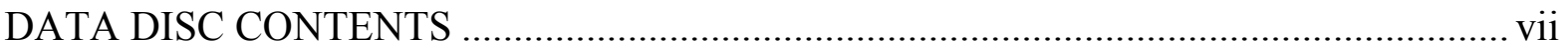

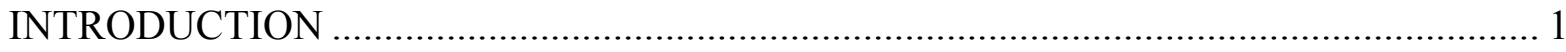

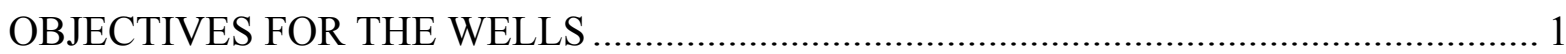

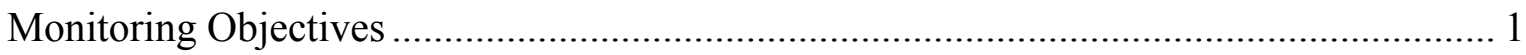

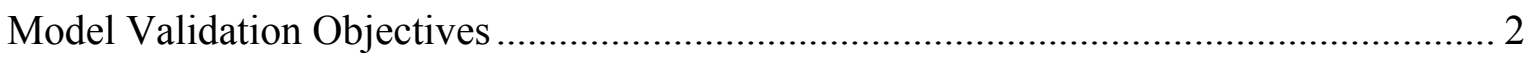

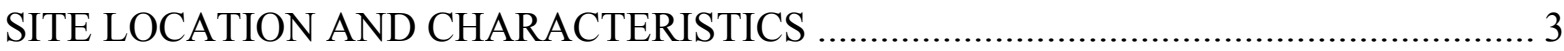

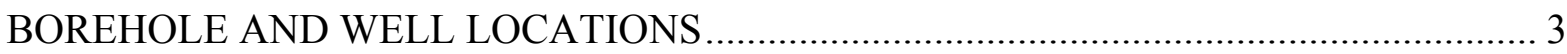

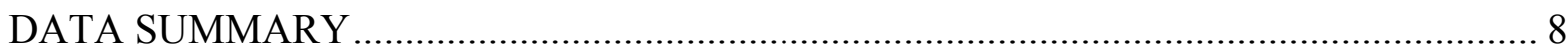

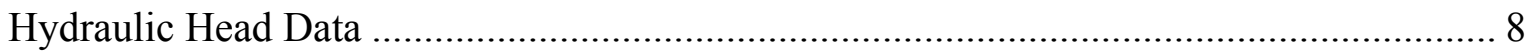

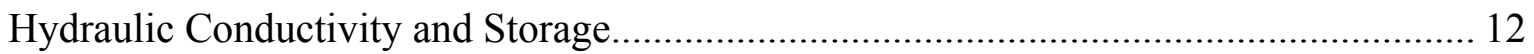

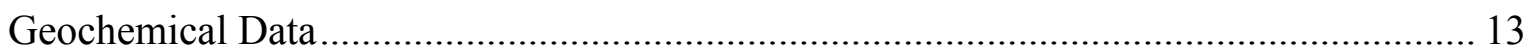

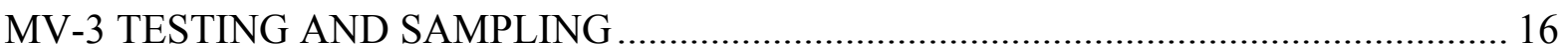

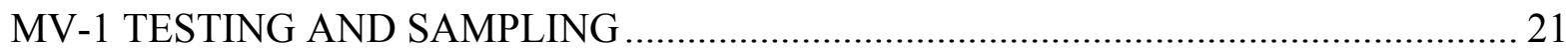

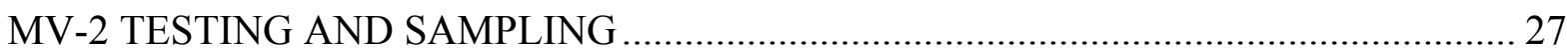

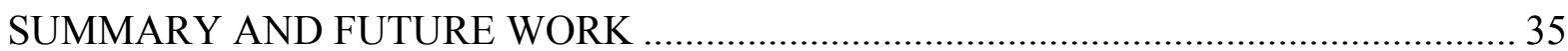

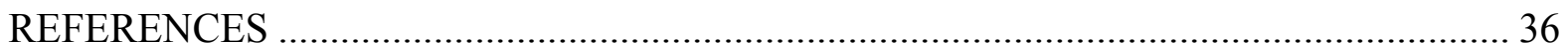

APPENDIX: PHOTOGRAPHS OF THE PSA WELL HEAD COMPLETIONS. ................. 39

Compact Disc (located in pocket on inside back cover) contains data files 


\section{LIST OF FIGURES}

1. Location of the Project Shoal Area in Churchill County, Nevada. ................................. 2

2. Location of wells near ground zero at the Project Shoal Area......................................... 4

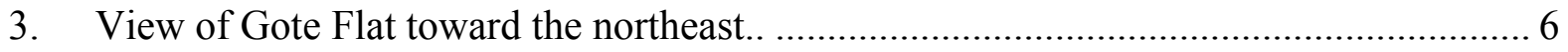

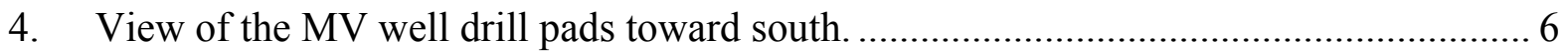

5. Photograph of PSA well MV-3 head completion. ........................................................ 7

6. Photograph of PSA well MV-1 head completion....................................................... 7

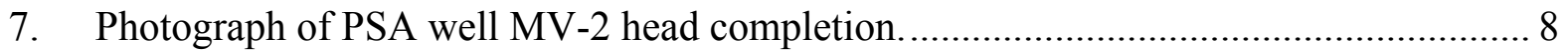

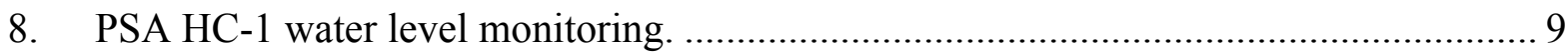

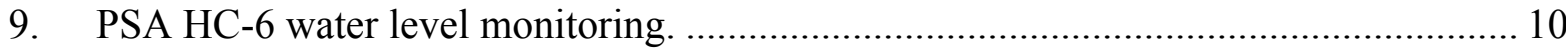

10. Hydrographs for the $\mathrm{HC}$ wells at the Shoal site for the time period from 1996 to

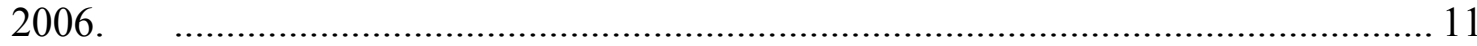

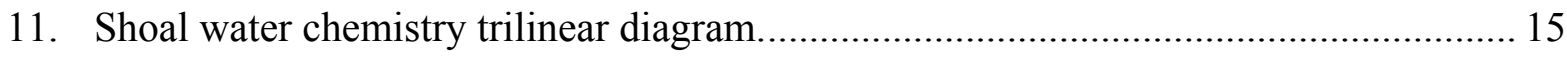

12. Shoal stable isotope plot of hydrogen versus oxygen. ................................................. 15

13. PSA MV-3 generalized well schematic and selected geophysical logs. ....................... 17

14. PSA MV-3 water level versus time for main well and piezometer................................ 18

15. PSA MV-3 water level drawdown during pumping, interpreted by the Cooper-Jacob method

16. PSA MV-3 water level drawdown during pumping, analyzed by the Hantush-Jacob leaky aquifer method

17. PSA MV-3 water level recovery following pumping, analyzed by the Cooper-Jacob method

18. PSA MV-1 generalized well schematic and selected geophysical logs. .......................... 23

19. PSA MV-1 water level versus time for main well and piezometer................................2 24

20. PSA MV-1 water level drawdown during pumping, interpreted by the Cooper-Jacob

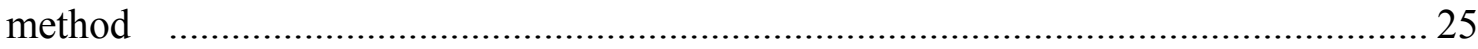

21. PSA MV-1water level drawdown during pumping, analyzed by the Hantush-Jacob

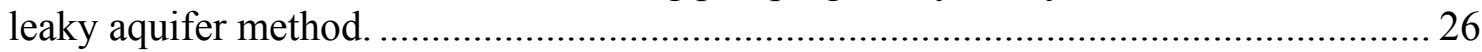

22a. PSA MV-1 water level recovery following pumping, plotted by the Cooper-Jacob method

22b. PSA MV-1 detailed late-time water level recovery following pumping, plotted by the Cooper-Jacob method.

23. PSA MV-2 generalized well schematic and selected geophysical logs. ........................ 29

24. PSA MV-2 water level versus time for main well. ........................................................ 30

25. PSA MV-2 water level drawdown during pumping, interpreted by the Cooper-Jacob method.

26. PSA MV-2 water level drawdown during pumping, analyzed by the Hantush-Jacob leaky aquifer method.

27. PSA HC-1 water level drawdown following pumping in well MV-2, plotted by the Cooper-Jacob method. 
28. PSA MV-2 water level recovery following pumping, analyzed by the Cooper-Jacob method.

29. PSA HC-1 water level recovery following MV-2 pumping, analyzed by the Cooper-Jacob method.

\section{LIST OF TABLES}

1. PSA well location coordinates in meters, relative to UTM-Zone 11, NAD 27, NAVD 29. 5

2. PSA model validation well drilling and testing chronology. ...................................... 8

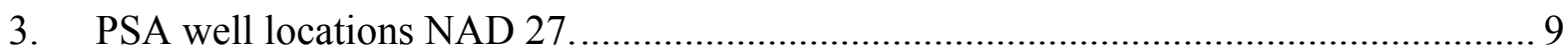

4. Selected static water level measurements from wells near the PSA. ........................... 12

5. Summary of hydraulic test data for wells near the PSA............................................ 13

6. Water chemistry data from wells near the PSA...................................................... 14

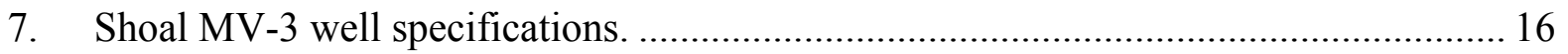

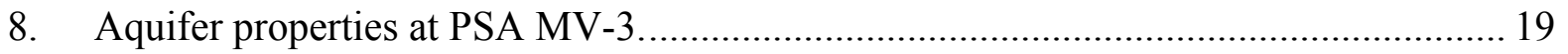

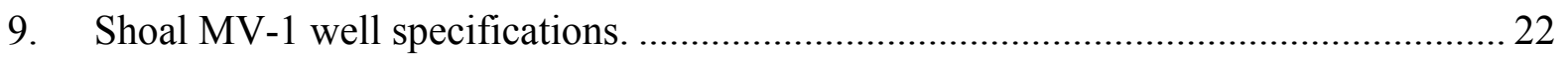

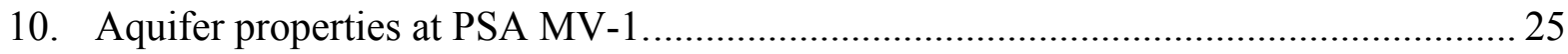

11. Shoal MV-2 well specifications. ......................................................................... 28

12. PSA MV-2 periodic water level measurements. ...................................................... 28

13. Aquifer properties at PSA MV-2 ...................................................................... 31

\section{LIST OF ACRONYMS}

CADD/CAP Corrective Action Decision Document/Corrective Action Plan

DOE U.S. Department of Energy

PSA Project Shoal Area

pCi/L pico Curies per liter

DataLogger

\section{DATA DISC CONTENTS}

Photos

Shoal Well Photos

Well Logs

Shoal Well Volume Calculations 
THIS PAGE INTENTIONALLY LEFT BLANK 


\section{INTRODUCTION}

The United States conducted the majority of underground nuclear testing at the Nevada Test Site, but a limited number of experiments were conducted in other locations. One of these is Project Shoal, located about 30 miles southeast of Fallon, Nevada (Figure 1). The Shoal test consisted of a 12-kiloton-yield nuclear detonation (DOE, 2000) that occurred on October 26, 1963. Project Shoal was part of studies to enhance seismic detection of underground nuclear tests, in particular, in active earthquake areas.

Characterization and remediation of groundwater contamination at the Project Shoal Area (PSA) is being conducted by the U.S. Department of Energy (DOE) under a Federal Facility and Consent Order with the State of Nevada Department of Environmental Protection and the U.S. Department of Defense. This order prescribes a Corrective Action Strategy, which involves conducting an investigation, reaching a decision on corrective action, implementing the corrective action, and reaching site closure. It is expected that longterm monitoring and site stewardship will continue past closure.

The investigation of the PSA is documented elsewhere (DOE, 1998; IT Corp., 2000; Pohll et al., 1998; Pohlmann et al., 2004). The investigation phase was completed with approval of the Corrective Action Decision Document/Corrective Action Plan (CADD/CAP) (DOE, 2006). The corrective action calls for installation and data collection from three new wells (named "MV" wells) at the site. The objectives of the wells are to provide monitoring locations and data for model validation purposes.

This report presents data and analysis pertinent to reaching the objectives of the monitoring validation (MV) wells prescribed by the Shoal CADD/CAP. Following this introduction, the objectives for the wells and background information on the site and well locations are presented. This is followed by summaries of the hydraulic, lithologic, and water chemistry data. Detailed information for each of the three MV wells is then presented, followed by a summary and discussion of ongoing and planned work. Digital data for the MV wells are included in a compact disc, located in a pocket on the inside back cover.

\section{OBJECTIVES FOR THE WELLS}

The two primary objectives for the PSA drilling and testing program were: (1) monitoring well installation and (2) model validation. The wells, MV-1, MV-2, and MV-3, were designed to meet these objectives. The MV wells are located north-northeast of PSA ground zero. The locations and completion intervals for these wells were selected along probably groundwater pathways, but contaminants are not predicted to travel the distance to the wells for hundreds of years. The depths of the wells are targeted to reduce uncertainty in the transport pathways downgradient from the nuclear test. Each well was constructed with a main well casing and a water level piezometer in the same borehole.

\section{Monitoring Objectives}

Analysis of the flow and transport model results indicate that the optimum monitoring well locations are north-northeast of ground zero, with optimum sampling elevations between 1,545 and $1,896 \mathrm{ft}$. These locations were determined by analyzing pathlines simulated by the stochastic model (Hassan, 2005). 


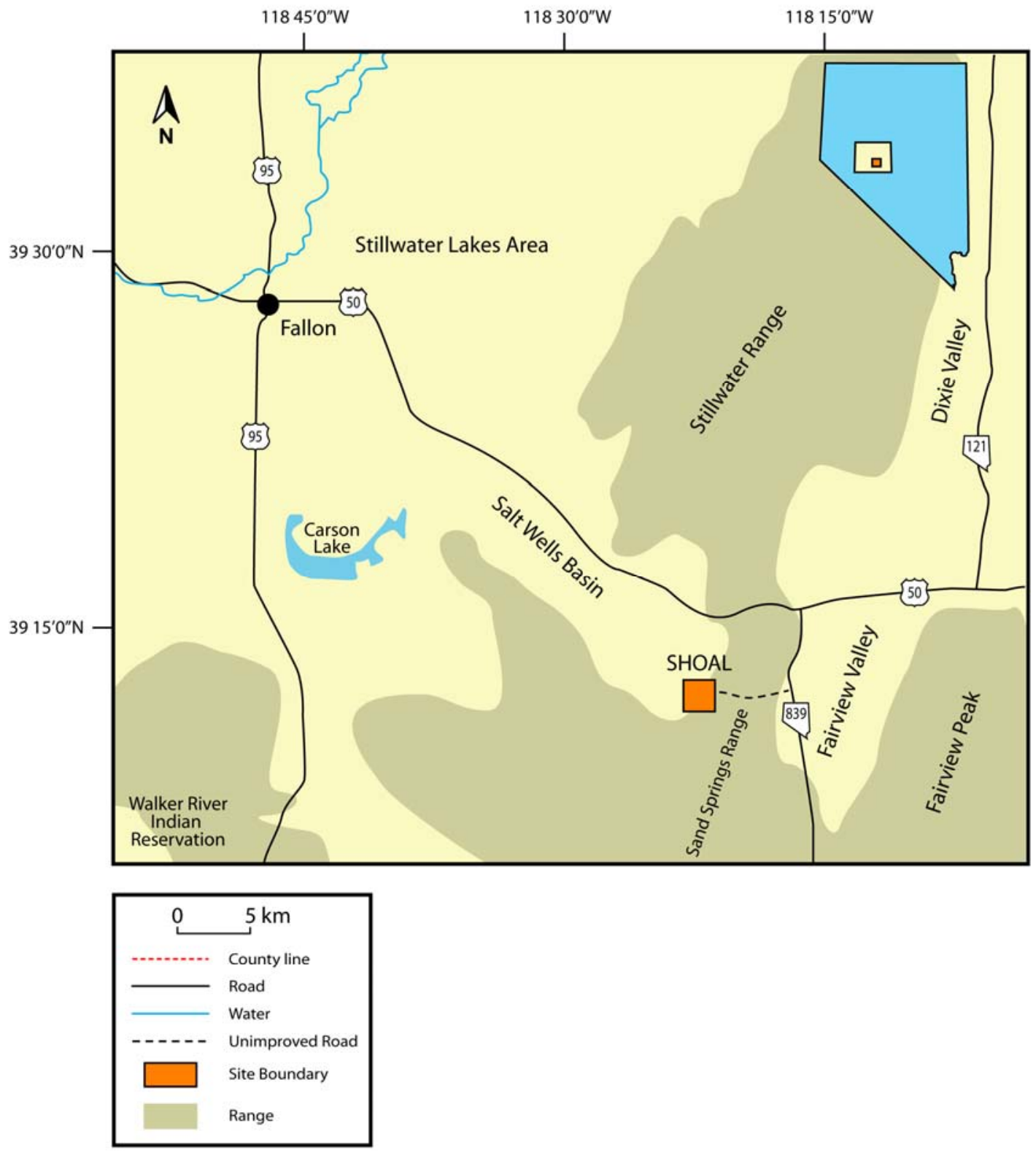

Figure 1. Location of the Project Shoal Area in Churchill County, Nevada.

\section{Model Validation Objectives}

The aspects of the PSA flow and transport models selected for validation constitute those considered key for effective monitoring, and those important to the calculated location of the contaminant boundary. The validation targets are:

1. Contaminant transport predictions.

2. Hydraulic conductivity range.

3. Groundwater flow and transport directions (hydraulic head distribution).

4. Fracture orientation and distribution. 
Confirming flow directions is vital to the effectiveness of groundwater monitoring. Fractures provide the only opportunities for significant groundwater flow through the granite, thus understanding fracture orientation and frequency is critical for groundwater predictions at the site. Confirming transport predictions (essentially ruling out fast pathways) is desirable, despite the low probability of detectable transport predicted by the model. Comparing the range of hydraulic conductivities in the new wells with those used in the model could confirm a major model parameter.

The corresponding approach determined for each target is summarized below:

1. Contaminant transport: collect and analyze groundwater samples for radionuclides.

2. Hydraulic conductivity: perform aquifer tests.

3. Groundwater flow directions: measure hydraulic head both laterally and vertically. In particular, the confirmation of generally downward and north-northeastward-directed lateral gradients at the test horizon is critical.

4. Fracture zones: log (including geophysical logs) the lithologic section in boreholes, with videologging in the unsaturated portion.

\section{SITE LOCATION AND CHARACTERISTICS}

The PSA consists of a 4-mi ${ }^{2}$ area in the Sand Springs Range, located near Fallon, Nevada, in Churchill County (Figure 1). Surface ground zero of the underground nuclear test is located at a land elevation of $5,230 \mathrm{ft}$ above mean sea level. The nuclear device was emplaced 1,204 ft below the land surface, at the end of a 1,000-ft long drift mined east from a vertical shaft.

The Sand Springs Range is a north-south-trending range with a total relief between the range and valleys of about 1,640 ft. A major intermittent drainage course in Ground Zero Canyon leads east to Fairview Valley. No permanent water bodies or streams exist on site. Sparse, low vegetation covers the area. The ground slopes steeply west to Fourmile Flat and east to Fairview Valley. Ground zero is near the crest on a minor intramountain plateau named Gote Flat, which is about $0.5 \mathrm{mi}$ wide. At a depth of 1,204 ft below the land surface, the Shoal working point is nearly at grade with the adjacent valley floors.

The Shoal site is in a subhumid to semiarid region of Nevada's Great Basin. Annual rainfall varies from about 5 inches (in) in the valleys to about 12 in in the high mountain ranges (Hardman and Mason, 1949). Most precipitation in the mountain ranges occurs as snow. The annual precipitation estimate for the Shoal site varies between 8 in (Gardner and Nork, 1970) and 12 in (Hardman and Mason, 1949). Daily temperature fluctuations in excess of $50^{\circ} \mathrm{F}$ can occur. Maximum temperatures exceed $100^{\circ} \mathrm{F}$ in July and August, and minimum temperatures of $0^{\circ} \mathrm{F}$ occur in December and January.

\section{BOREHOLE AND WELL LOCATIONS}

Wells have been drilled and constructed at the PSA in the past (Figure 2 and Table 1). The first wells were constructed as part of activities in support of the underground nuclear test in the early 1960s. The wells installed at this time on Gote Flat include ECH-D, ECH-A, USBM-1, PM-1, PM-2, and PM-3. All of these wells were plugged and abandoned and are no longer accessible. The next sequence of drilling occurred in 1996 with the onset of 
environmental remediation. At this time, wells HC-1, HC-2, HC-3, and HC-4 were constructed. Wells HC-5, HC-6, HC-7, and HC-8 were installed in 1999 and a year-long tracer test was conducted between HC-6 and HC-7. Finally, the MV wells were drilled and constructed in 2006. HC-1 through HC-8 (except for HC-2 and HC-3) and MV-1 through MV-3 can be seen in Figure 2. Many of these wells can be seen from a vantage point toward the west of Gote Flat looking east (Figure 3). An additional photograph, taken from the hills due south of the MV drilling pads, gives a view of the site while drilling activities were in progress (Figure 4). Each MV well was protected in a 2-ft by 2-ft lockable steel box, as seen in photographs of the MV-3, MV-1, and MV-2 well heads (Figures 5 through 7, respectively). Photographs of the previously drilled HC wells (with the exception of HC-4) are included in the Appendix.

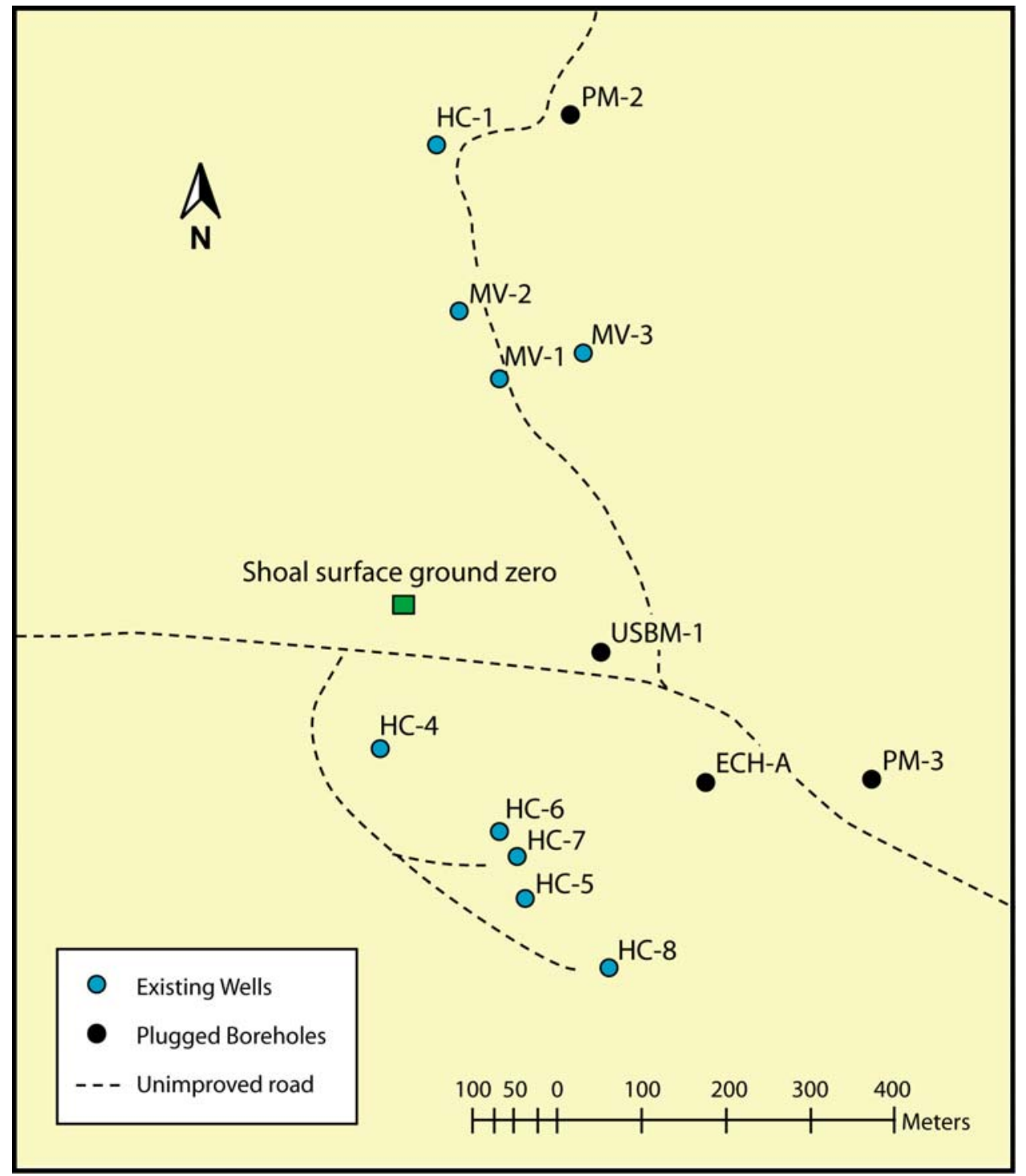

Figure 2. Location of wells near ground zero at the Project Shoal Area. Well HC-2 is located out of view to the west and HC-3 to the east. 
Table 1. PSA well location coordinates in meters, relative to UTM-Zone 11, NAD 27, NAVD 29. The results of previous surveys are given, in addition to locations measured in the 2006 survey reported by DOE (2006).

\begin{tabular}{|c|c|c|c|c|c|c|}
\hline Well ID & $\begin{array}{c}\text { Northing } \\
2006 \text { survey } \\
(\mathrm{m})\end{array}$ & $\begin{array}{l}\text { Northing } \\
\text { Pre-2006 } \\
\text { (m) }\end{array}$ & $\begin{array}{c}\text { Easting } \\
2006 \text { survey } \\
(\mathrm{m})\end{array}$ & $\begin{array}{c}\text { Easting } \\
\text { Pre-2006 } \\
(\mathrm{m}) \\
\end{array}$ & $\begin{array}{c}\text { Elevation } \\
2006 \text { survey } \\
(\mathrm{ft})\end{array}$ & $\begin{array}{c}\text { Elevation } \\
\text { Pre-2006 } \\
(\mathrm{ft})\end{array}$ \\
\hline MV-1 & 4339959.5 & - & 380918.5 & - & $5,257.5$ & - \\
\hline MV-2 & 4340042.8 & - & 380875.2 & - & $5,266.7$ & - \\
\hline MV-3 & 4339986.1 & - & 381026.9 & - & $5,261.5$ & - \\
\hline HC-1 & 4340242.9 & 4340238.9 & 380850.3 & 380850.5 & $5,309.4$ & $5,309.4$ \\
\hline $\mathrm{HC}-2$ & 4339729.4 & 4339731.9 & 380258.4 & 380259.5 & $5,347.1$ & $5,347.1$ \\
\hline $\mathrm{HC}-3$ & 4339282.4 & 4339282.9 & 381673.1 & 381669.5 & $5,081.7$ & $5,081.7$ \\
\hline $\mathrm{HC}-4$ & 4339522.7 & 4339520.9 & 380785.3 & 380783.5 & $5,260.8$ & $5,260.8$ \\
\hline $\mathrm{HC}-5$ & 4339338.8 & 4336341.9 & 380957.7 & 380954.5 & $5,247.4$ & $5,247.0$ \\
\hline HC-6 & 4339417.4 & 4339418.9 & 380930.8 & 380926.5 & $5,228.7$ & $5,228.3$ \\
\hline $\mathrm{HC}-7$ & 4339394.1 & 4339394.9 & 380951.5 & 380945.5 & $5,229.7$ & $5,229.3$ \\
\hline $\mathrm{HC}-8$ & 4339255.7 & 4339261.9 & 381056.0 & 381054.5 & $5,259.8$ & $5,259.5$ \\
\hline PM-1 & - & 4339320.9 & - & 380315.5 & - & $5,357.9$ \\
\hline PM-2 & - & 4340273.9 & - & 381010.5 & - & $5,317.6$ \\
\hline PM-3 & - & 4339482.9 & - & 381365.5 & - & $5,130.2$ \\
\hline ECH-A & - & 4339482.9 & - & 381172.5 & - & $5,158.8$ \\
\hline ECH-D & - & 4339693.7 & - & 380814.1 & - & $5,229.0$ \\
\hline USBM-1 & - & 4339634.9 & - & 381046.5 & - & $5,211.9$ \\
\hline \multicolumn{5}{|c|}{ Offsite wells of interest } & - & - \\
\hline $\mathrm{H}-2$ & - & 4343246.3 & - & 376481.1 & - & $4,017.1$ \\
\hline $\mathrm{H}-3$ & - & 4341919.7 & - & 378211.4 & - & $4,232.3$ \\
\hline HS-1 & - & 4340189.0 & - & 386713.0 & - & $4,242.8$ \\
\hline US Navy EW & - & 4352932.6 & - & 394532.8 & - & \\
\hline Range & & & & & & $4,215.9$ \\
\hline Frenchman's & - & 4348279.6 & - & 390458.5 & - & \\
\hline Station & & & & & & $4,153.2$ \\
\hline
\end{tabular}




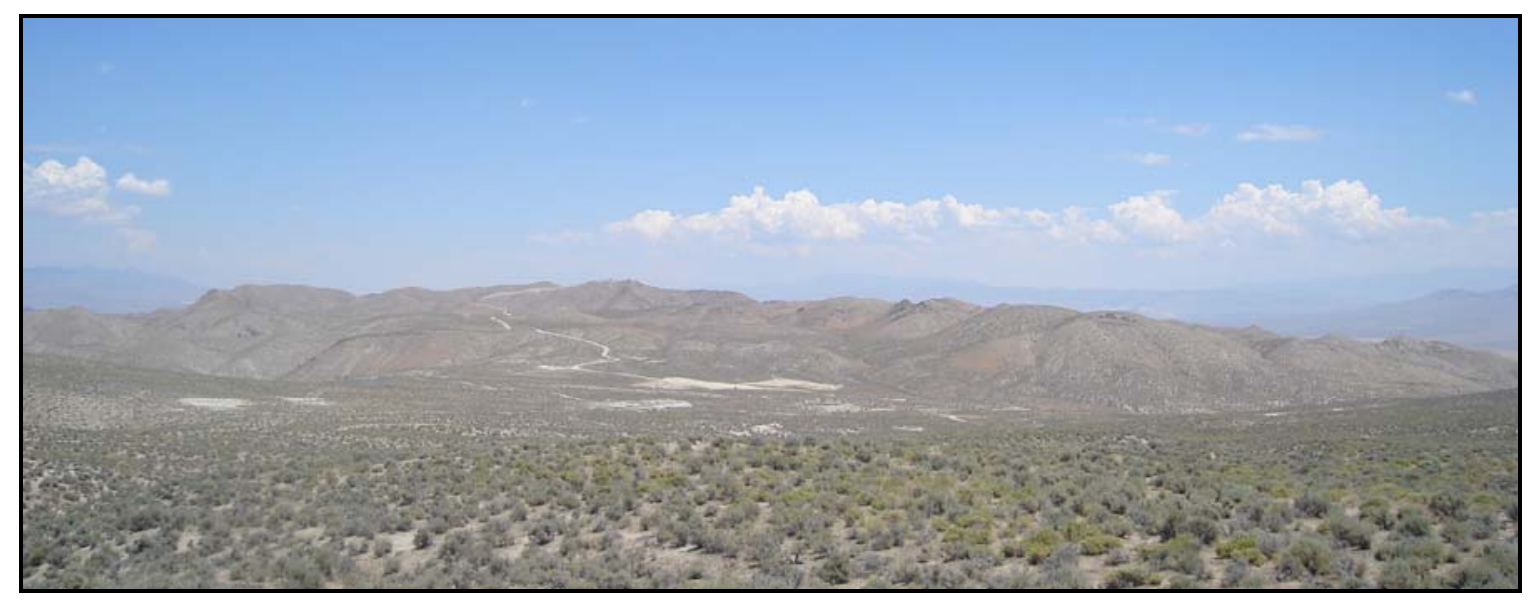

Figure 3. View of Gote Flat toward the northeast (photograph taken 6/30/2006). The MV well pads are in the center of the photo.

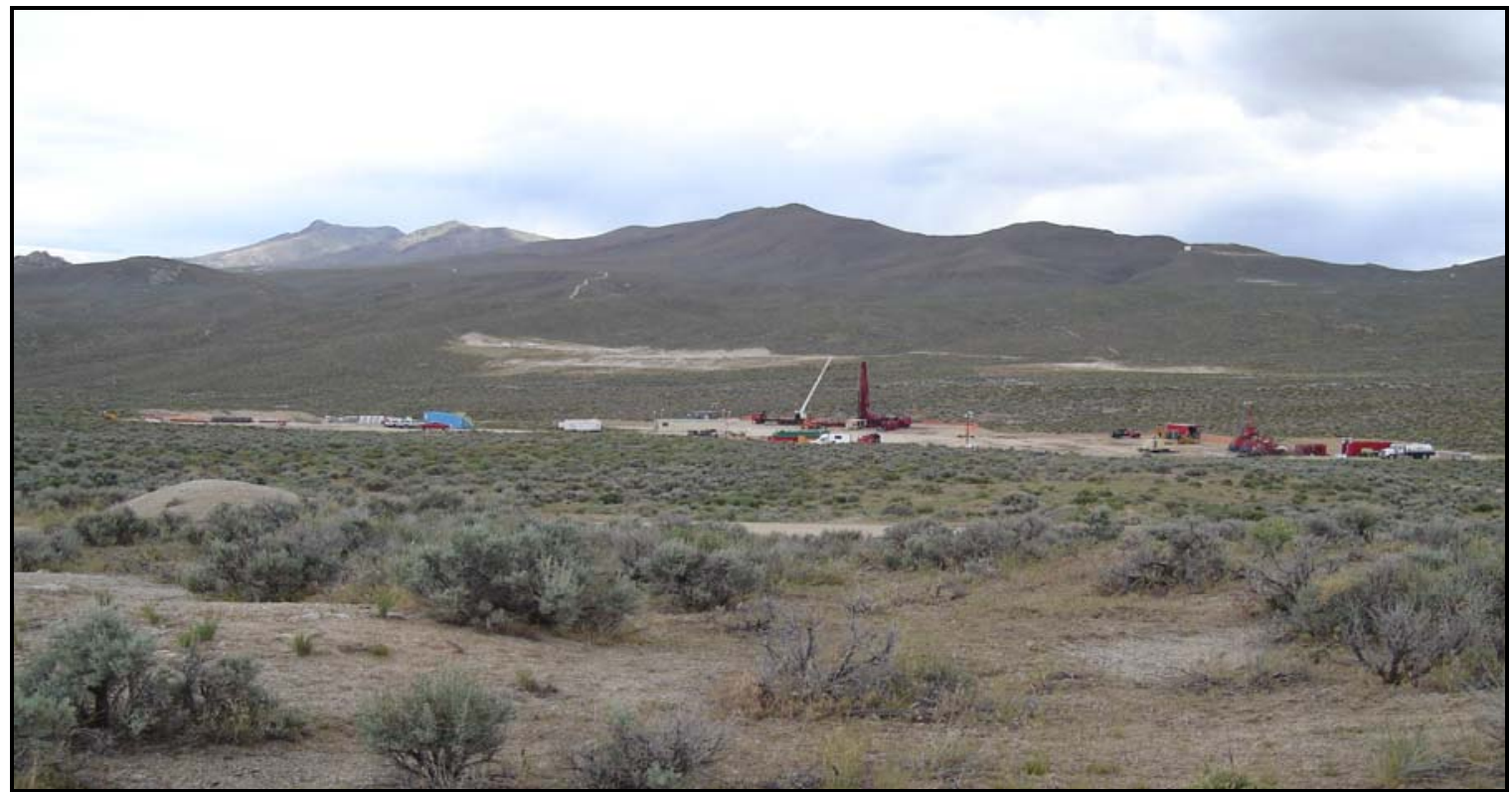

Figure 4. View of the MV well drill pads toward the south (photograph taken 5/22/2006). MV-3 is to the left, MV-1 is center, and MV-2 is toward the right. 


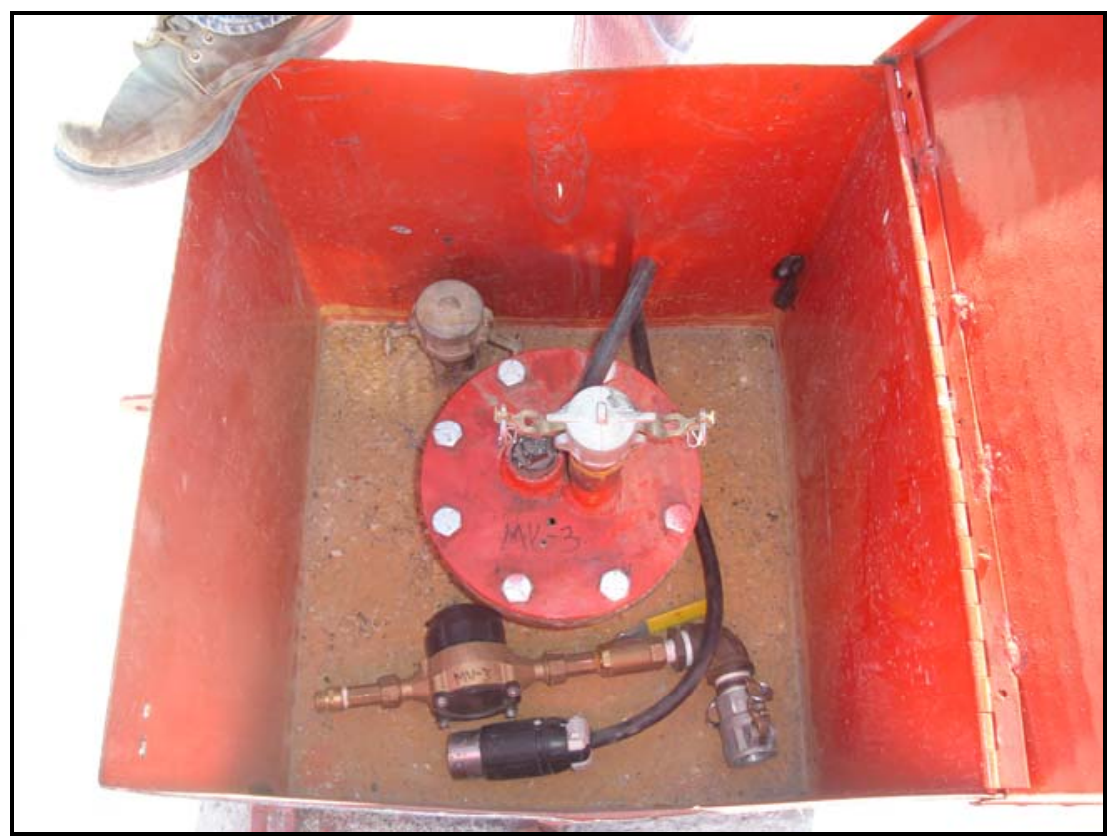

Figure 5. Photograph of PSA well MV-3 head completion (photograph taken 9/12/2006). The flowmeter and electrical plug can be seen in the bottom center of the photo, the piezometer is near the top left, the pump discharge line is center right (aluminum camlock), and the water level sounding tube is in the left center (black pipe plug) of the photo.

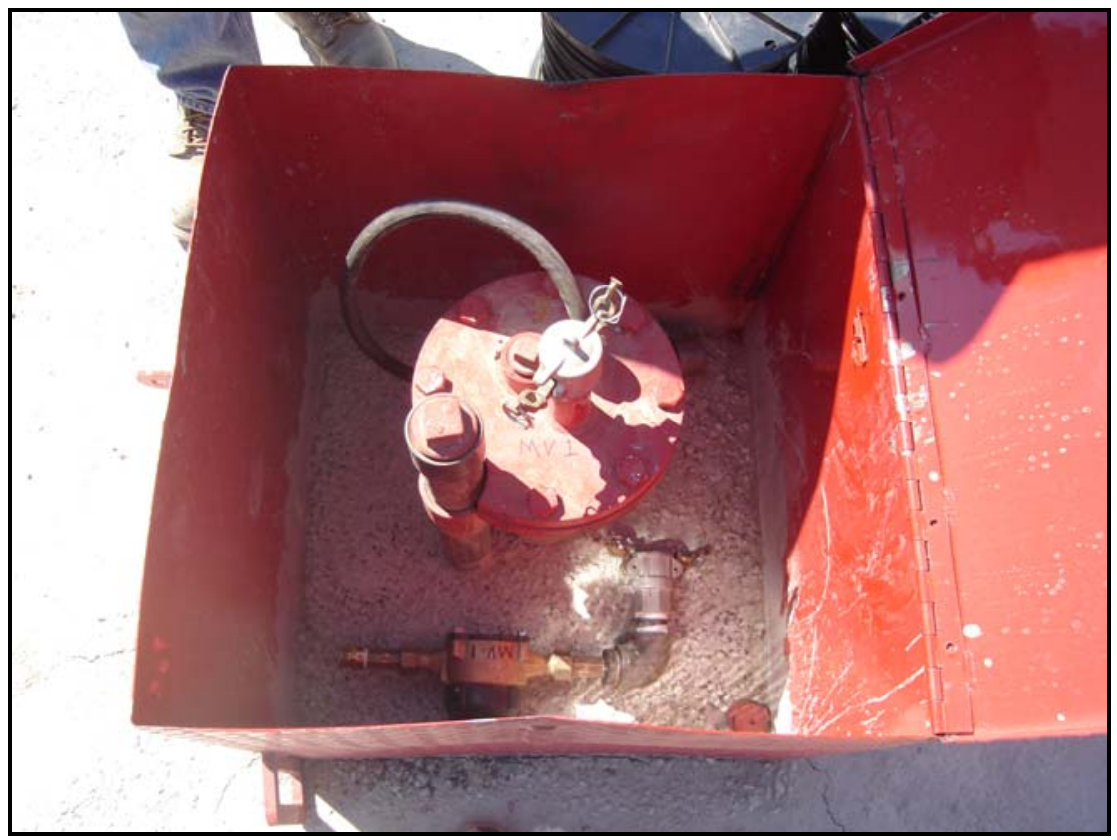

Figure 6. Photograph of PSA well MV-1 head completion (photograph taken 9/12/2006). The flowmeter can be seen in the bottom center of the photo, the electrical plug is under the pump flange at the top of the photo, the piezometer is in the left-lower quadrant of the pump flange, the pump discharge line is in the right center of the pump flange (aluminum cam-lock), and the water level sounding tube is in the left center of the pump flange (red pipe plug) in the center of the photo. 


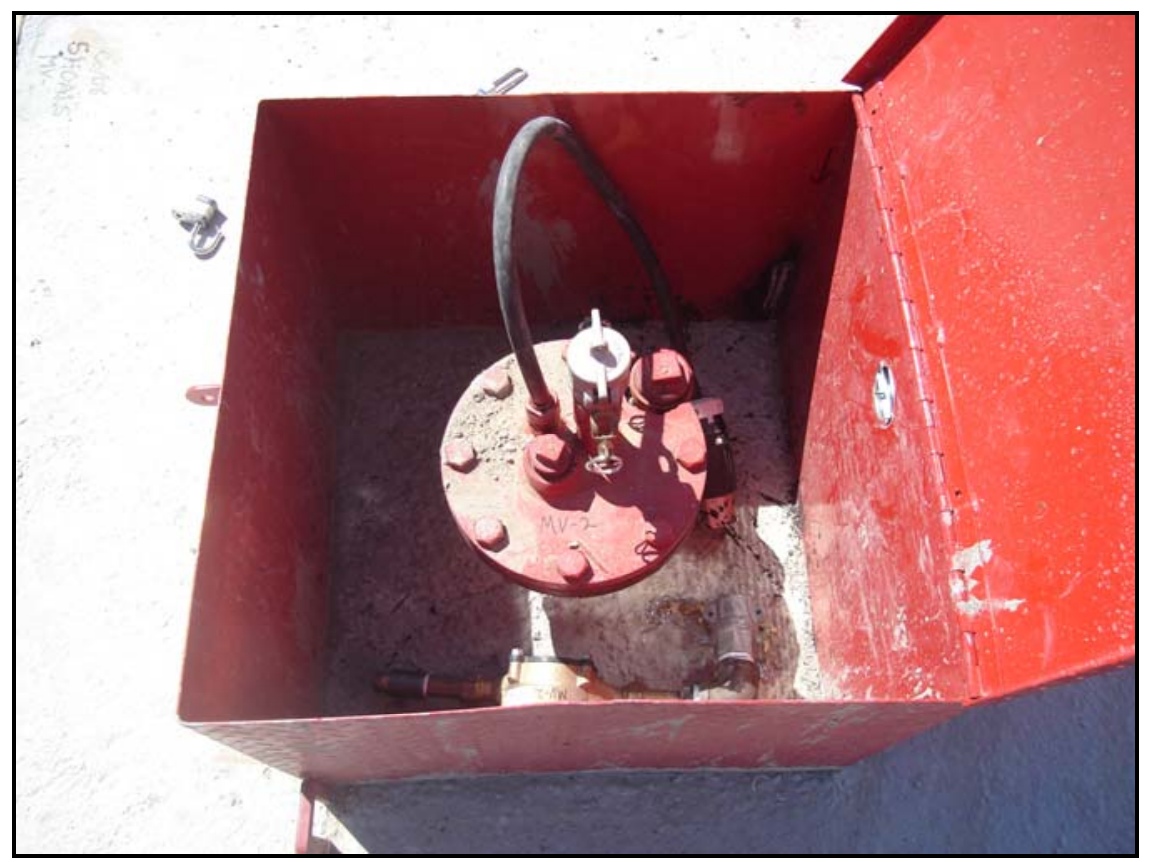

Figure 7. Photograph of PSA well MV-2 head completion (photograph taken 9/12/2006). The flowmeter can be seen at the bottom center of the photo, the pump electrical plug is on the right side below the pump flange, the piezometer is in the upper right quadrant of the pump flange, the pump discharge line is in the right center of the pump flange (aluminum cam-lock), and the water level sounding tube is in the left center of the pump flange (red pipe plug) in the center of the photo.

\section{DATA SUMMARY}

Three monitoring-validation wells were drilled, tested, and sampled as part of this project; the wells were drilled sequentially from shallowest to deepest. MV-3 was drilled first, then MV-1, and MV-2 was drilled last. The well drilling and test chronology are summarized in Table 2. Details of well drilling activities are in the Shoal well completion report (DOE, 2006).

Table 2. PSA model validation well drilling and testing chronology.

\begin{tabular}{llll}
\hline & MV-1 & MV-2 & MV-3 \\
\hline Start drilling & May 8, 2006 & May 23, 2006 & April 3, 2006 \\
End development & June 14, 2006 & June 19, 2006 & June 4, 2006 \\
Collect water samples & June 30, 2006 & June 28, 2006 & June 29, 2006 \\
Start aquifer test & July 19, 2006 & July 25, 2006 & July 10, 2006 \\
End aquifer test & July 25, 2006 & August 6, 2006 & July 14, 2006 \\
\hline
\end{tabular}

\section{Hydraulic Head Data}

Water levels were monitored at PSA wells HC-1 and HC-6 during the construction and hydraulic testing of wells MV-1, MV-2, and MV-3. These wells are located in proximity 
to the MV wells as presented in Table 3. Barometric pressure was also monitored at the site during well construction. The monitoring results for $\mathrm{HC}-1$ and $\mathrm{HC}-6$ are presented in Figures 8 and 9, respectively. The figures demonstrate that the hydraulic effects of well construction and hydraulic testing of the MV wells were transmitted to the monitoring wells at distances of up to 2,000 ft. With these data, the barometric air pressure effects on water levels could not be distinguished from the hydraulic effects of drilling and testing.

Table 3. PSA well locations NAD 27.

\begin{tabular}{lccccc}
\hline $\begin{array}{c}\text { Monitoring } \\
\text { Well }\end{array}$ & $\begin{array}{c}\text { Northing } \\
(\mathrm{m})\end{array}$ & $\begin{array}{c}\text { Easting } \\
(\mathrm{m})\end{array}$ & $\begin{array}{c}\text { Elevation } \\
(\mathrm{ft})\end{array}$ & $\begin{array}{c}\text { Distance to HC-1 } \\
(\mathrm{ft})\end{array}$ & $\begin{array}{c}\text { Distance to HC-6 } \\
(\mathrm{ft})\end{array}$ \\
\hline MV-1 & 4339959.9 & 380918.4 & $5,256.2$ & 955.1 & $1,780.4$ \\
MV-2 & 4340043.0 & 380874.8 & $5,265.7$ & 660.8 & $2,060.8$ \\
MV-3 & 4339986.3 & 381026.5 & $5,260.5$ & $1,021.3$ & $1,892.7$ \\
HC-1 & 4340242.9 & 380850.3 & $5,309.4$ & - & $2,721.3$ \\
HC-6 & 4339417.4 & 380930.8 & $5,228.7$ & $2,721.3$ & - \\
\hline
\end{tabular}

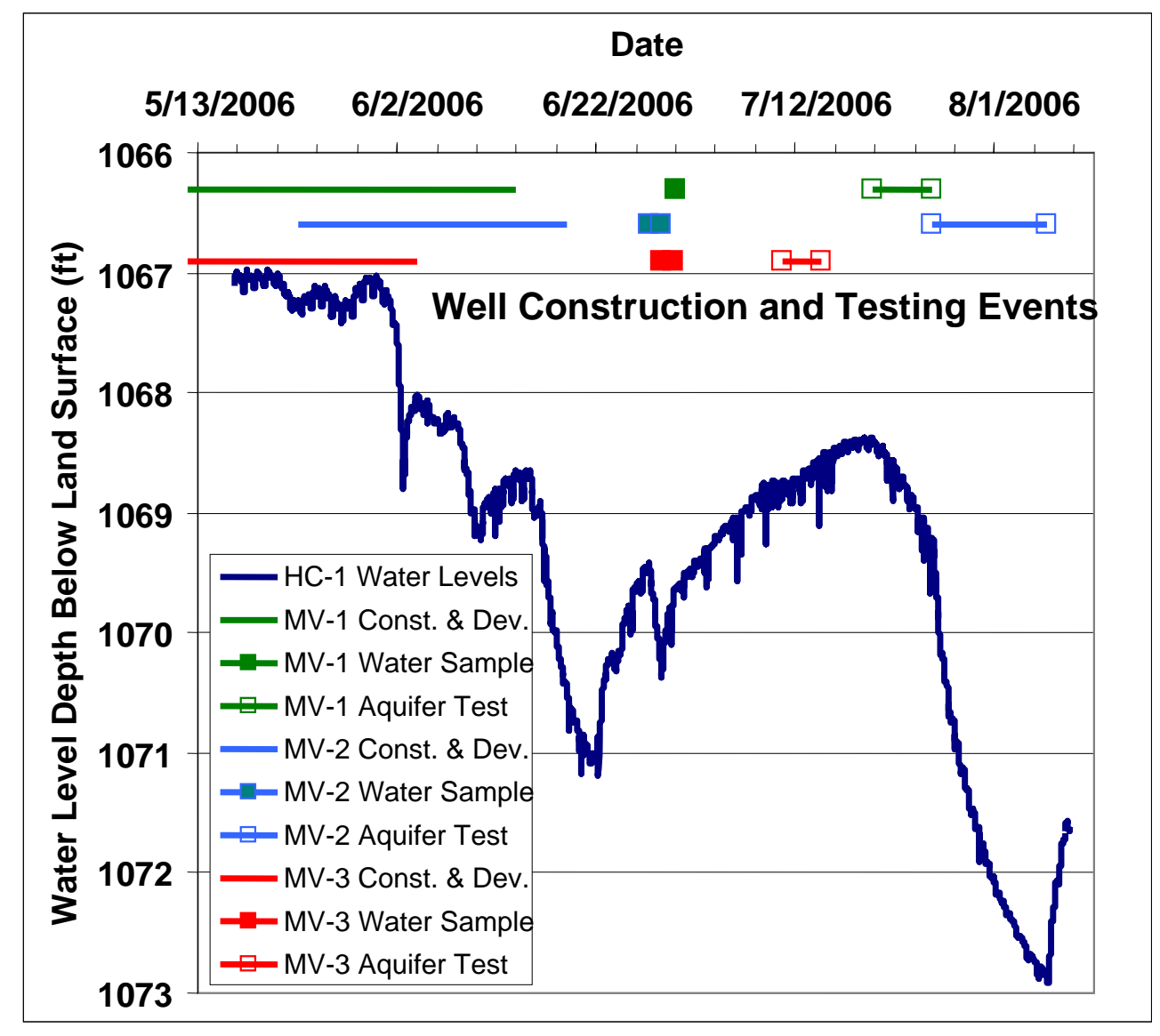

Figure 8. PSA HC-1 water level monitoring. 


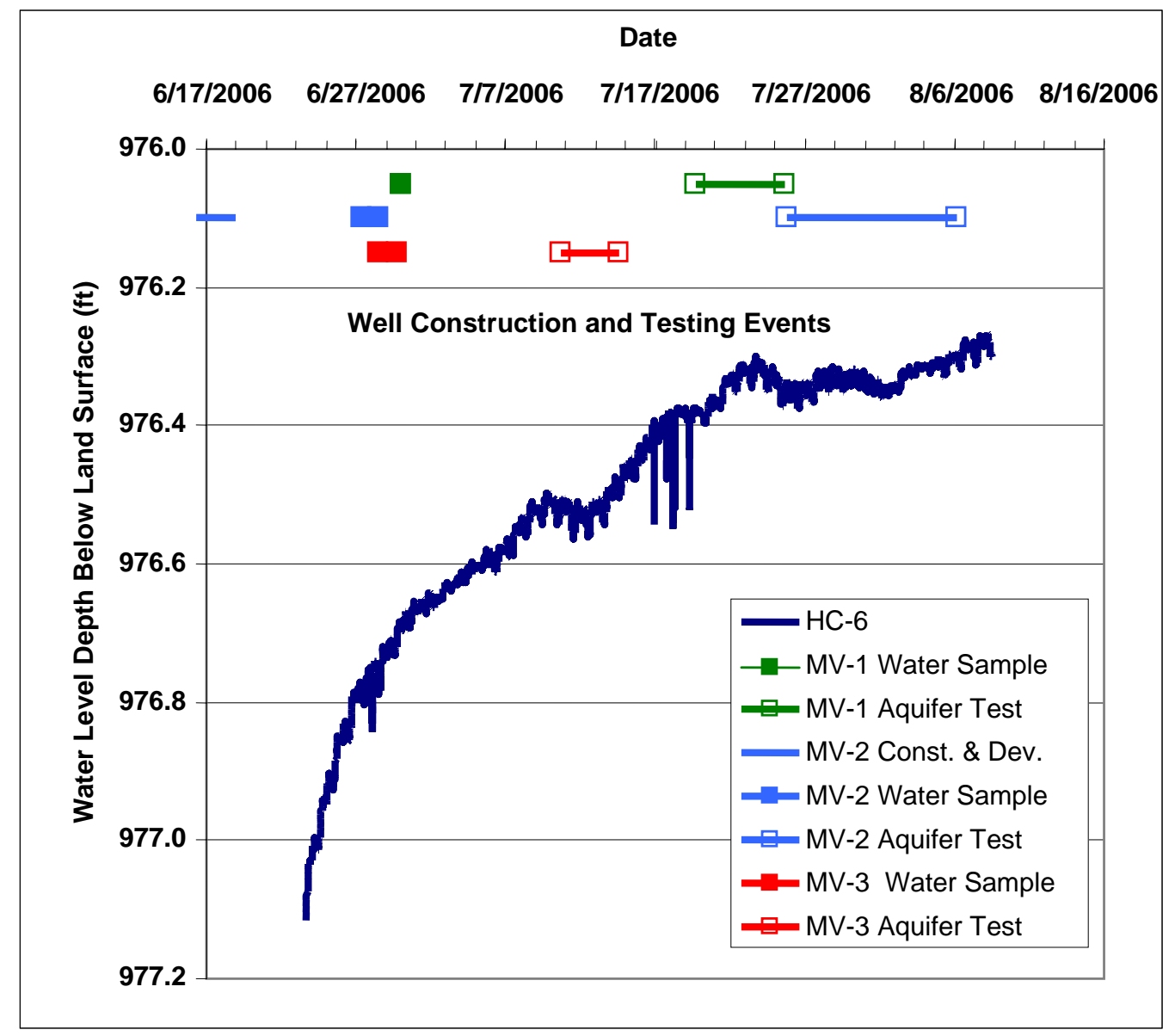

Figure 9. PSA HC-6 water level monitoring.

Water levels for $\mathrm{HC}-1$ indicate several drawdown and recovery responses ranging from 1 to $4 \mathrm{ft}$. Well construction and development in May and June clearly affected HC-1, but it is not apparent which pumping well(s) was responsible for the hydraulic responses. $\mathrm{HC}-1$ may have responded to the development of MV-2 at the end of the construction activity and to MV-1 and MV-2 during aquifer testing. The water levels in $\mathrm{HC}-1$ at the end of July and beginning of August are characteristic of a drawdown and recovery response to nearby pumping. The water levels in $\mathrm{HC}-1$ during the MV-2 aquifer test are used in calculating aquifer parameters

Water levels recorded in well HC-6 (Figure 9) are more subtle and have a range of less than $1 \mathrm{ft}$. The water levels were also rising over the monitoring period, making it difficult to attribute perturbations to a specific well construction or testing activity. The well may have responded to the aquifer tests at MV-2 and MV-3, but distinguishing the drawdown response from the response to other events and/or processes cannot be accomplished with confidence. The data from monitoring well HC-6 were not used to quantify aquifer properties. 
Water levels in the HC wells have been monitored since their construction. A slow trend of increasing hydraulic head can be observed in the wells to the west of the shear zone (Figure 10). A summary of water level measurements for wells at the PSA is presented in Table 4.
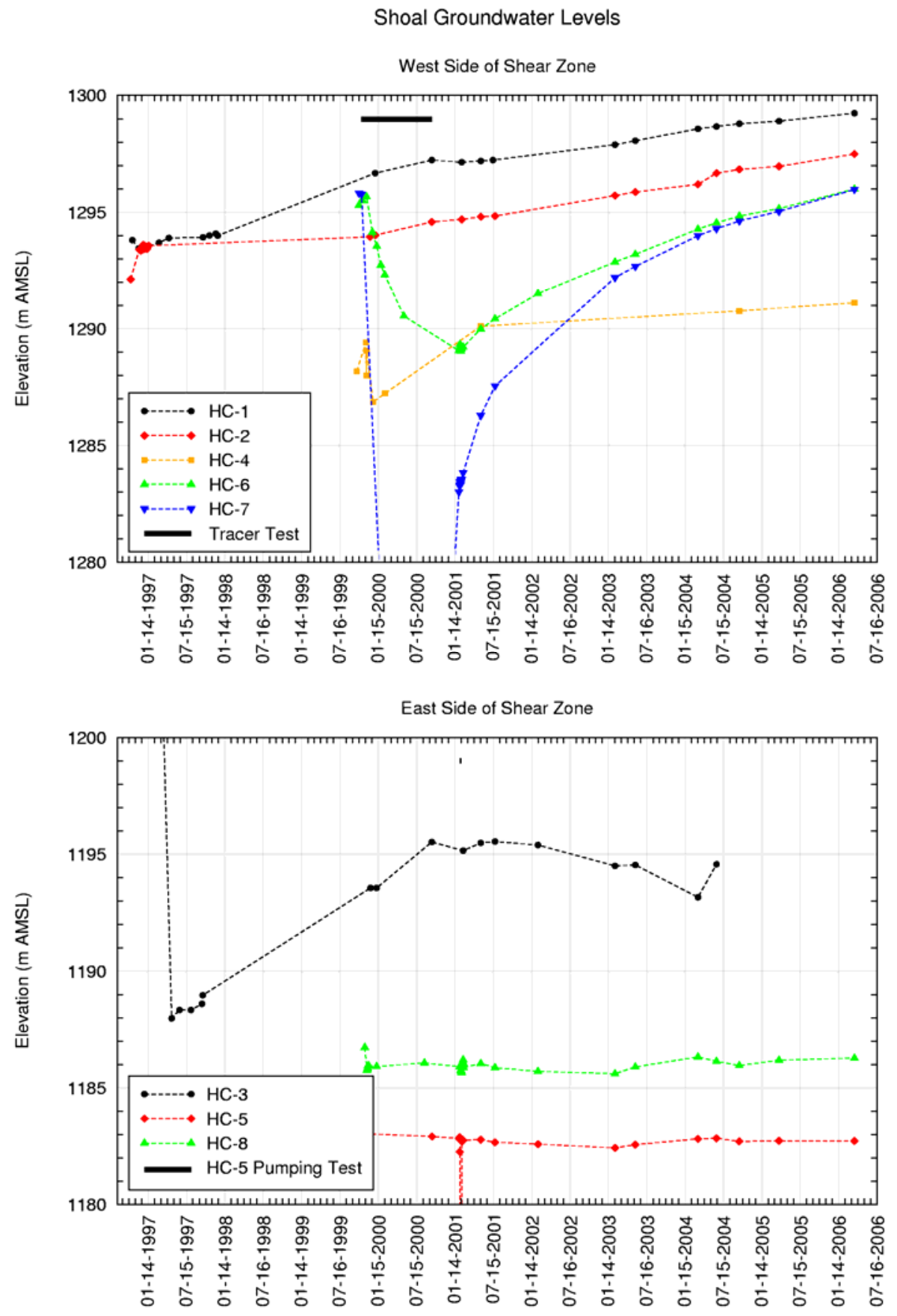

Figure 10. Hydrographs for the HC wells at the Shoal site for the time period from 1996 to 2006. 
Table 4. Selected static water level measurements from wells near the PSA.

\begin{tabular}{lccc}
\hline Well ID & $\begin{array}{c}\text { Top } \\
\text { (ft AMSL) }\end{array}$ & $\begin{array}{c}\text { Base } \\
\text { (ft AMSL) }\end{array}$ & $\begin{array}{c}\text { Water Level } \\
\text { (ft AMSL) }\end{array}$ \\
\hline MV-1 Well & $3,684.7$ & $3,531.2$ & $4,221.5$ \\
MV-1 Piezometer & $3,919.0$ & $3,858.9$ & $4,221.1$ \\
MV-2 Well & $3,446.9$ & $3,275.9$ & $4,252.6$ \\
MV-2 Piezometer & $4,079.1$ & $4,019.4$ & - \\
MV-3 Well & $3,797.9$ & $3,627.0$ & $4,275.6$ \\
MV-3 Piezometer & $4,120.1$ & $4,060.0$ & $4,274.9$ \\
HC-1 & $4,244.4$ & $3,978.7$ & $4,254.3$ \\
HC-2 & $4,241.1$ & $4,134.2$ & $4,245.4$ \\
HC-3 & $4,217.5$ & $3,886.5$ & $3,916.0$ \\
HC-4 & $4,217.5$ & $4,029.9$ & $4,230.6$ \\
HC-5 & $1,865.5$ & $1,745.4$ & $3,881.2$ \\
HC-6 & $4,239.8$ & $4,119.8$ & $4,250.3$ \\
HC-7 & $4,239.8$ & $4,005.9$ & $4,251.3$ \\
HC-8 & $2,965.2$ & $2,848.8$ & $3,890.7$ \\
PM-1 & $4,263.5$ & $4,019.0$ & $4,263.5$ \\
PM-2 & $4,449.8$ & $4,022.6$ & $4,449.8$ \\
PM-3 & $4,224.1$ & $4,033.1$ & $4,059.1$ \\
ECH-D & $4,265.1$ & $3,213.9$ & $4,265.1$ \\
\hline
\end{tabular}

\section{Hydraulic Conductivity and Storage}

Pumping tests were performed in the MV wells at the conclusion of well installation and development. The details of the MV tests are provided in subsequent sections of this report. Estimates of hydraulic conductivity are also available for the $\mathrm{HC}$ wells from pumping tests and from smaller-scale tests using a downhole thermal flowmeter (TFM). Results from hydraulic tests in wells at the Shoal site are summarized in Table 5. There is a wide range in the hydraulic properties of fractured granite. The extreme hydraulic conductivity values can be as low as $0.001 \mathrm{ft} / \mathrm{d}$ or as high as $100 \mathrm{ft} / \mathrm{d}$. The values more likely to be encountered have a minimum of $0.05 \mathrm{ft} / \mathrm{d}$ and a maximum of $10 \mathrm{ft} / \mathrm{d}$. The hydraulic conductivity values determined at the Shoal Project Area wells MV-1, MV-2, and MV-3 are near or just below the likely minimums (Halford and Kuniansky, 2002). 
Table 5. Summary of hydraulic test data for wells near the PSA.

\begin{tabular}{|c|c|c|c|c|c|c|c|}
\hline Well ID & Test & Year & $\begin{array}{c}\text { Top } \\
\text { (ft AMSL) }\end{array}$ & $\begin{array}{c}\text { Tested Interva } \\
\text { Base } \\
\text { (ft AMSL) }\end{array}$ & $\begin{array}{l}\text { Length } \\
(\mathrm{ft})\end{array}$ & $\begin{array}{c}K \\
(\mathrm{ft} / \mathrm{d})\end{array}$ & $\mathrm{S}$ \\
\hline MV-1 & Pumping & 2006 & $3,684.7$ & $3,531.2$ & 160.1 & $1.44 \mathrm{E}-02$ & \\
\hline MV-2 & Pumping & 2006 & $3,446.9$ & $3,275.9$ & 120.1 & 4.82E-01 & $2.14 \mathrm{E}-04$ \\
\hline MV-3 & Pumping & 2006 & $3,797.9$ & $3,627.0$ & 160.1 & $7.1 \mathrm{E}-02$ & \\
\hline $\mathrm{HC}-1$ & Pumping ${ }^{1}$ & 1997 & $4,244.4$ & $3,978.7$ & 265.7 & $5.9 \mathrm{E}-02$ & \\
\hline $\mathrm{HC}-2$ & Pumping & 1997 & $4,241.1$ & $4,134.1$ & 107.0 & $7.5 \mathrm{E}-03$ & \\
\hline $\mathrm{HC}-4$ & Pumping & 1997 & $4,217.5$ & $4,019.3$ & 198.2 & $1.1 \mathrm{E}-02$ & \\
\hline $\mathrm{HC}-5$ & Pumping $^{1}$ & 1999 & $1,865.4$ & $1,745.4$ & 120.1 & $5.6 \mathrm{E}-01$ & \\
\hline $\mathrm{HC}-6$ & Pumping & 1999 & $4,239.7$ & $4,119.7$ & 120.1 & 4.6E-02 & \\
\hline $\mathrm{HC}-7$ & Pumping & 1999 & $4,239.7$ & $4,005.9$ & 120.1 & $7.5 \mathrm{E}-02$ & \\
\hline $\mathrm{HC}-8$ & Pumping & 1999 & $2,965.4$ & $2,848.9$ & 120.1 & $2.7 \mathrm{E}-03$ & \\
\hline HC-7/HC-6 & Pumping ${ }^{2}$ & 1999 & $4,239.7$ & $4,119.7$ & 120.1 & $4.9 \mathrm{E}-01$ & 0.01 \\
\hline $\mathrm{HC}-1$ & TFM & 1997 & $4,075.7$ & $4,044.0$ & 31.5 & $1.5 \mathrm{E}-01$ & \\
\hline $\mathrm{HC}-1$ & TFM & 1997 & $4,044.0$ & $4,021.9$ & 22.3 & $2.0 \mathrm{E}-01$ & \\
\hline $\mathrm{HC}-4$ & TFM & 1997 & $4,239.0$ & $4,219.3$ & 19.7 & $2.8 \mathrm{E}-02$ & \\
\hline $\mathrm{HC}-4$ & TFM & 1997 & $4,219.3$ & $4,179.9$ & 39.4 & $9.5 \mathrm{E}-03$ & \\
\hline $\mathrm{HC}-4$ & TFM & 1997 & $4,179.9$ & $4,157.0$ & 23.0 & $6.6 \mathrm{E}-03$ & \\
\hline $\mathrm{HC}-4$ & TFM & 1997 & $4,157.0$ & $4,117.6$ & 39.4 & $4.3 \mathrm{E}-03$ & \\
\hline $\mathrm{HC}-4$ & TFM & 1997 & $4,117.6$ & $4,088.1$ & 29.5 & $1.0 \mathrm{E}-02$ & \\
\hline $\mathrm{HC}-4$ & TFM & 1997 & $4,088.1$ & $4,055.2$ & 32.8 & $2.8 \mathrm{E}-03$ & \\
\hline $\mathrm{HC}-4$ & TFM & 1997 & $4,055.2$ & $4,029.0$ & 26.2 & $1.2 \mathrm{E}-02$ & \\
\hline
\end{tabular}

${ }^{1}$ Mean value of two tests

${ }^{2}$ Pumping in HC-7, observations in HC-6

\section{Geochemical Data}

Water quality sampling was conducted after development of the wells was completed and bromide concentrations were at background levels, indicating drilling makeup water had been removed from the formation. Water quality sampling was performed before aquifer testing. Analytical results are included in Table 6; results from previously sampled wells are also included for comparison. Major ions from the MV wells are similar to those encountered in groundwater from the $\mathrm{HC}$ wells as shown on the trilinear diagram in Figure 11; however, MV-1, 2, and 3 are chemically more similar to HC-1, 2, and 4 than to the other HC wells or to HS-1. The well waters can be classified as a mixed-type water. Stable isotopes plot along a local meteoric water line, and are relatively depleted in heavy isotopes, indicative of recharge in a cooler climatic period (Figure 12). No analytical results suggested radionuclide transport; however, detectable tritium was observed in well MV-3 (it should be noted the levels observed are near current atmospheric background levels).

Water level measurements were performed periodically with an electrical tape before the installation of pressure transducers and continuous recording dataloggers. Aquifer tests were performed in each well after final well development was completed; aquifer test results are summarized in Table 2. Well MV-2 produced more discharge near the end of the test, indicating that the well may not have been fully developed before testing. Water levels were monitored during aquifer test recovery and are inclusive to August 31, 2006. 
Table 6. Water chemistry data from wells near the PSA.

\begin{tabular}{|c|c|c|c|c|c|c|c|c|c|c|c|c|c|c|c|c|}
\hline Well & $\begin{array}{c}\text { Depth } \\
\text { (ft) }\end{array}$ & Date & $\begin{array}{c}\mathrm{T} \\
\left({ }^{\circ} \mathrm{C}\right) \\
\end{array}$ & $\mathrm{pH}^{*}$ & $\begin{array}{c}\begin{array}{c}E C^{*} \\
(\mu \mathrm{S} / \mathrm{cm})\end{array} \\
\end{array}$ & $\mathrm{SiO}_{2}$ & $\mathrm{Ca}$ & $\mathrm{Mg}$ & $\mathrm{Na}$ & $\mathrm{K}$ & $\mathrm{Cl}$ & $\mathrm{SO}_{4}$ & $\mathrm{HCO}_{3}{ }^{*}$ & $\mathrm{NO}_{3}$ & $\mathrm{~F}$ & $\mathrm{Br}$ \\
\hline HC-1 & 1,102 & $02 / 21 / 1997$ & 13.6 & 8.01 & 467 & 19.8 & 45.7 & 6.01 & 38.7 & 2.79 & 48 & 52.2 & 116 & 11.1 & 0.4 & 0.7 \\
\hline $\mathrm{HC}-2$ & 1,139 & 03/19/1997 & na & 8.03 & 670 & 20.8 & 58.1 & 7.87 & 64.8 & 3.48 & 81 & 108 & 118 & 0.44 & 0.3 & 0.59 \\
\hline $\mathrm{HC}-4$ & 1,073 & 02/24/1997 & 13.7 & 8.04 & 727 & 22.7 & 66.4 & 9.87 & 63.7 & 3.67 & 101 & 90.3 & 113 & 26.8 & 0.35 & 1.67 \\
\hline HC-5 & 1,562 & $01 / 12 / 2000$ & 31.5 & 8.26 & 948 & 32.2 & 31.6 & 0.2 & 170 & 2.24 & 92 & 228 & 83.5 & 0.31 & & 0.23 \\
\hline HC-6 & 1,217 & $10 / 06 / 1999$ & 24.0 & 7.72 & 1,060 & 26.1 & 139 & 19.6 & 58.5 & 4.43 & 126 & 235 & 133 & 16.7 & & 0.4 \\
\hline $\mathrm{HC}-7$ & 1,217 & $11 / 03 / 1999$ & 20.5 & 7.75 & 1,380 & 24.4 & 178 & 26.4 & 77 & 5.18 & 189 & 329 & 165 & 0.58 & & 0.6 \\
\hline HC-8 & 2,001 & $10 / 29 / 1999$ & 26.6 & 8.16 & 799 & 30 & 37.6 & 0.44 & 130 & 3.12 & 120 & 133 & 91.5 & 0.04 & & 0.3 \\
\hline HS-1 & 301 & 03/30/1992 & na & 8.14 & 438 & 68.7 & 31.5 & 5.37 & 47.2 & 7.11 & 29 & 51.5 & 140 & 3.99 & & 0.1 \\
\hline MV-1 & 1,650 & $06 / 30 / 2006$ & 23.0 & 7.65 & 737 & 21.4 & 60.7 & 5.71 & 77.0 & 3.84 & 101 & 118 & 99.5 & 0.93 & & 0.85 \\
\hline MV-2 & 1,905 & $06 / 28 / 2006$ & 23.0 & 7.75 & 542 & 22.6 & 46.8 & 4.77 & 53.6 & 2.67 & 71 & 73.5 & 112 & 1.98 & & 0.27 \\
\hline MV-3 & 1,548 & $06 / 29 / 2006$ & 23.3 & 7.73 & 852 & 19.8 & 85.0 & 7.94 & 67.5 & 4.76 & 126 & 139 & 89.2 & 1.15 & & 0.082 \\
\hline
\end{tabular}

*First number is a measurement in the field at the time of sample collection. Second number is a laboratory measurement. If there is only one number, it is a laboratory measurement (concentrations in $\mu \mathrm{g} / \mathrm{L}$, unless noted otherwise)

$\mu \mathrm{S} / \mathrm{cm}=$ microsiemens per centimeter

$\%$ per mil

Isotopic and radiochemical analyses for groundwater samples from the PSA.

\begin{tabular}{cccccc}
\hline Well & Percent modern carbon & $\delta^{13} \mathrm{C}(\%)$ & $\delta^{18} \mathrm{O}(\%)$ & $\delta \mathrm{D}(\%)$ & $\begin{array}{c}\text { Tritium } \\
(\mathrm{pCi} / \mathrm{L})\end{array}$ \\
\hline HC-1 & $48.68 \pm 0.83$ & -10.8 & -14.5 & -114 & $<5$ \\
HC-2 & $22.13 \pm 0.51$ & -10.4 & -14.5 & -115 & $<5$ \\
HC-4 & $5,408 \pm 51.9$ & -11.2 & -14.2 & -113 & $1,130 \pm 5$ \\
HC-5 & $6.47 \pm 0.24$ & -8.5 & -14.9 & -122 & $<2.6$ \\
HC-6 & $12.26 \pm 0.18$ & -9.9 & -13.8 & -113 & $<2.6$ \\
HC-7 & $7.45 \pm 0.15$ & -9.2 & -13.9 & -115 & $<2.6$ \\
HC-8 & $9.61 \pm 0.15$ & -9.7 & -14.4 & -117 & $<2.6$ \\
HS-1 & $8.3 \pm 0.9$ & -9.9 & -16.3 & -123 & $<10$ \\
MV-1 & $20.9 \pm 0.18$ & -10.1 & -13.8 & -115 & $<3$ \\
MV-2 & $36.04 \pm 0.23$ & -10.0 & -13.8 & -116 & $4 \pm 9$ \\
MV-3 & $21.53 \pm 0.19$ & -10.1 & -13.8 & -115 & $13 \pm 9$ \\
\hline
\end{tabular}



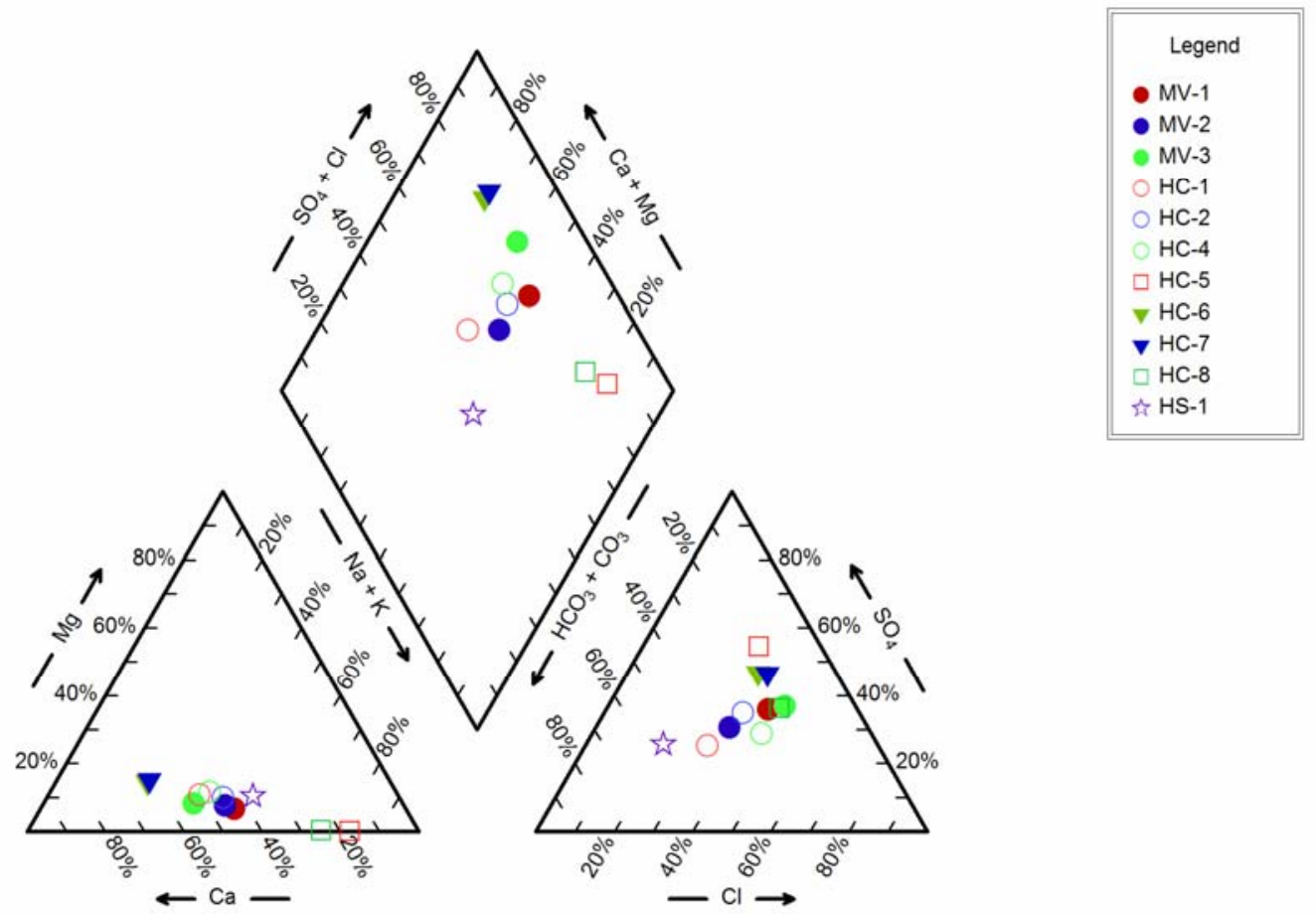

Figure 11. Shoal water chemistry trilinear diagram.
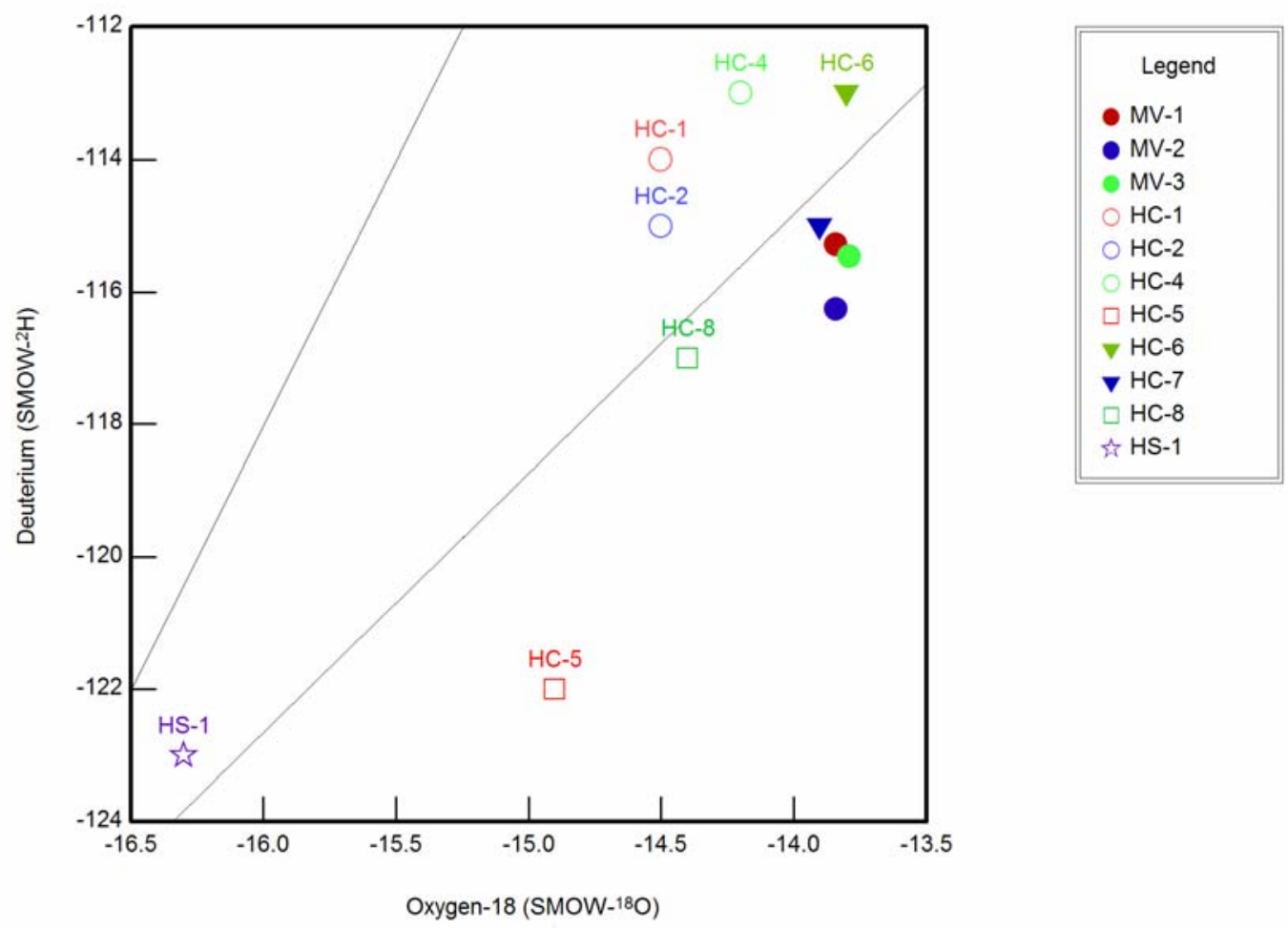

Figure 12. Shoal stable isotope plot of hydrogen versus oxygen. Craig's meteoric water line $\left(\delta \mathrm{D}=8 \delta^{18} \mathrm{O}+10\right)$ and local meteoric water line are shown for reference. 


\section{MV-3 TESTING AND SAMPLING}

Well MV-3 was drilled to a total depth of 1,669 ft; well screen was installed from 1,464 to $1,635 \mathrm{ft}$, specifically targeting a highly fractured area identified from drilling and geophysical log information. The piezometer was screened from 1,140 to $1,200 \mathrm{ft}$, and was generally targeted to be near the water table (Table 7). A generalized well schematic, including selected geophysical logs, are shown in Figure 13. All geophysical logs are included on a data $\mathrm{CD}$ accompanying this report.

Table 7. Shoal MV-3 well specifications.

\begin{tabular}{lc}
\hline Northing (m) UTM-NAD27 & $4,339,986.122$ \\
Easting (m) UTM-NAD27 & $381,026.9$ \\
Elevation (AMSL) (m) NAVD 29 & $1,603.71$ \\
Well Total Depth (ft) & $1,668.84$ \\
Well Top of Screen (ft) & $1,463.59$ \\
Well Bottom of Screen (ft) & $1,634.75$ \\
Top of Gravel (ft) & 1,363 \\
Bottom of Gravel (ft) & 1,668 \\
Piezometer Top of Screen (ft) & $1,140.42$ \\
Piezometer Bottom of Screen (ft) & $1,200.45$ \\
Piezometer Top of Gravel (ft) & 1,049 \\
Piezometer Bottom of Gravel (ft) & 1,203 \\
Estimated Wellbore Volume (gal) & 1,145 \\
\hline
\end{tabular}

Well drilling was performed with the dual-tube flooded reverse circulation technique. Well construction was started April 3, 2006, and completed May 4, 2006. Airlift development was performed with the drilling rig for approximately 48 hours, and was completed May 6, 2006. Airlift development continued until solids were no longer visible in the well discharge. Final well development was performed with the dedicated submersible sample pump. The well was pumped periodically during daylight shifts from June 2 to 4 , 2006.

Piezometer development was performed June 1 to 8, 2006, with a pump setting rig, using a combination of wireline bailing and airlifting. Production rates varied from 0.4 to 1 gallon per minute. Turbidity measurements and bromide analyses showed gradual decreases, and both water quality parameters were reduced to near background levels by the end of the well development activities.

Water quality samples were collected after at least three well volumes were purged and field parameters (i.e., temperature, electrical conductance, $\mathrm{pH}$ ) stabilized. The well volume was assumed to be the wellbore volume plus volume of water in the gravel pack, assuming 30 percent porosity (Table 7). Field measurements of temperature, electrical conductance and $\mathrm{pH}$ were monitored for stability before sample collection. Analytical results are included in Table 6; samples from previously sampled wells are included for comparison. Major cations and anions, stable isotopes and radio isotopes are similar to other wells in the area. No analytes indicated radionuclide transport. 


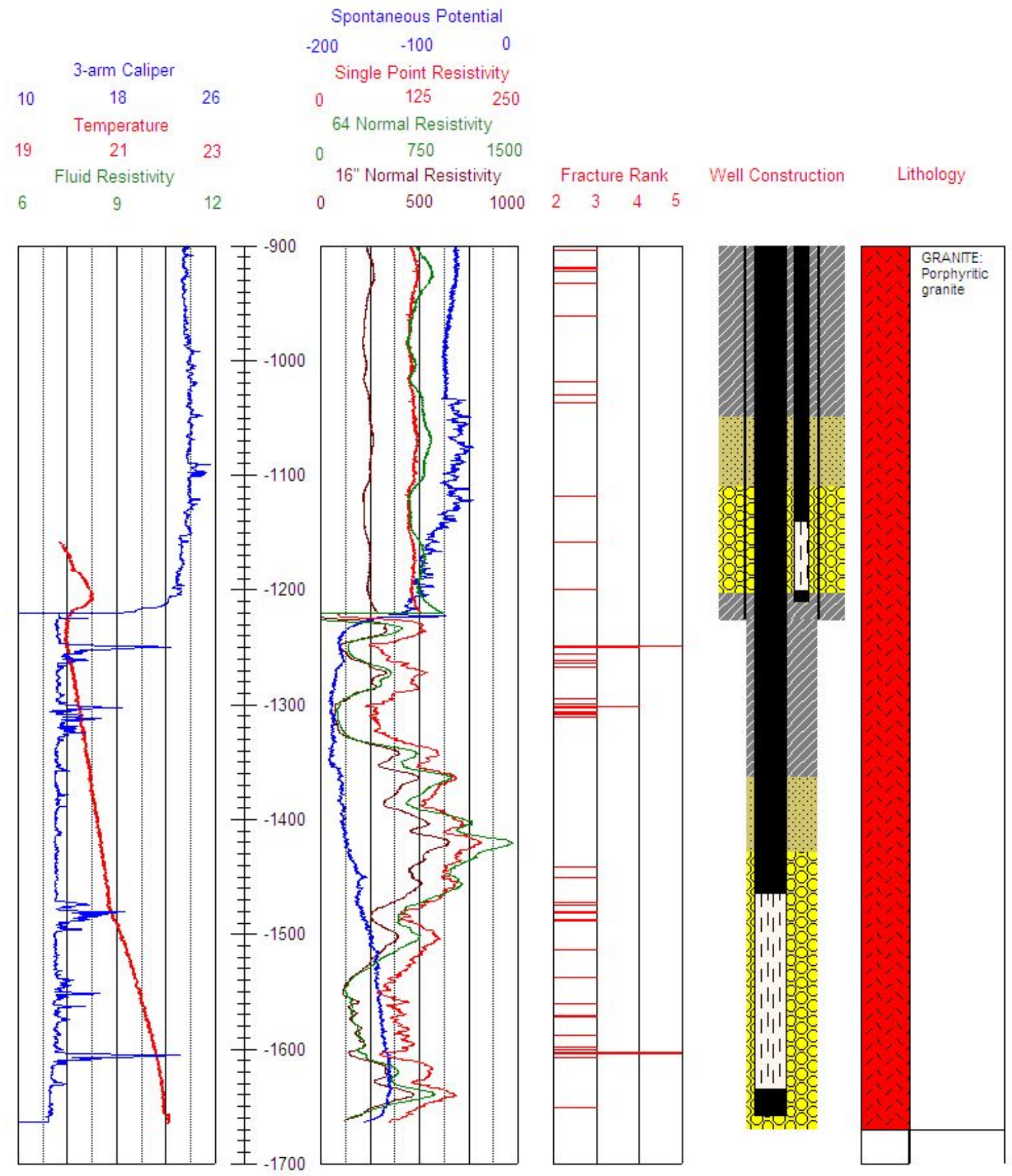

Figure 13. PSA MV-3 generalized well schematic and selected geophysical logs.

An aquifer test was performed from July 25 to August 6, 2006; water levels were continuously monitored with a transducer in the main well and in the piezometer, during the drawdown and recovery (Figure 14). 


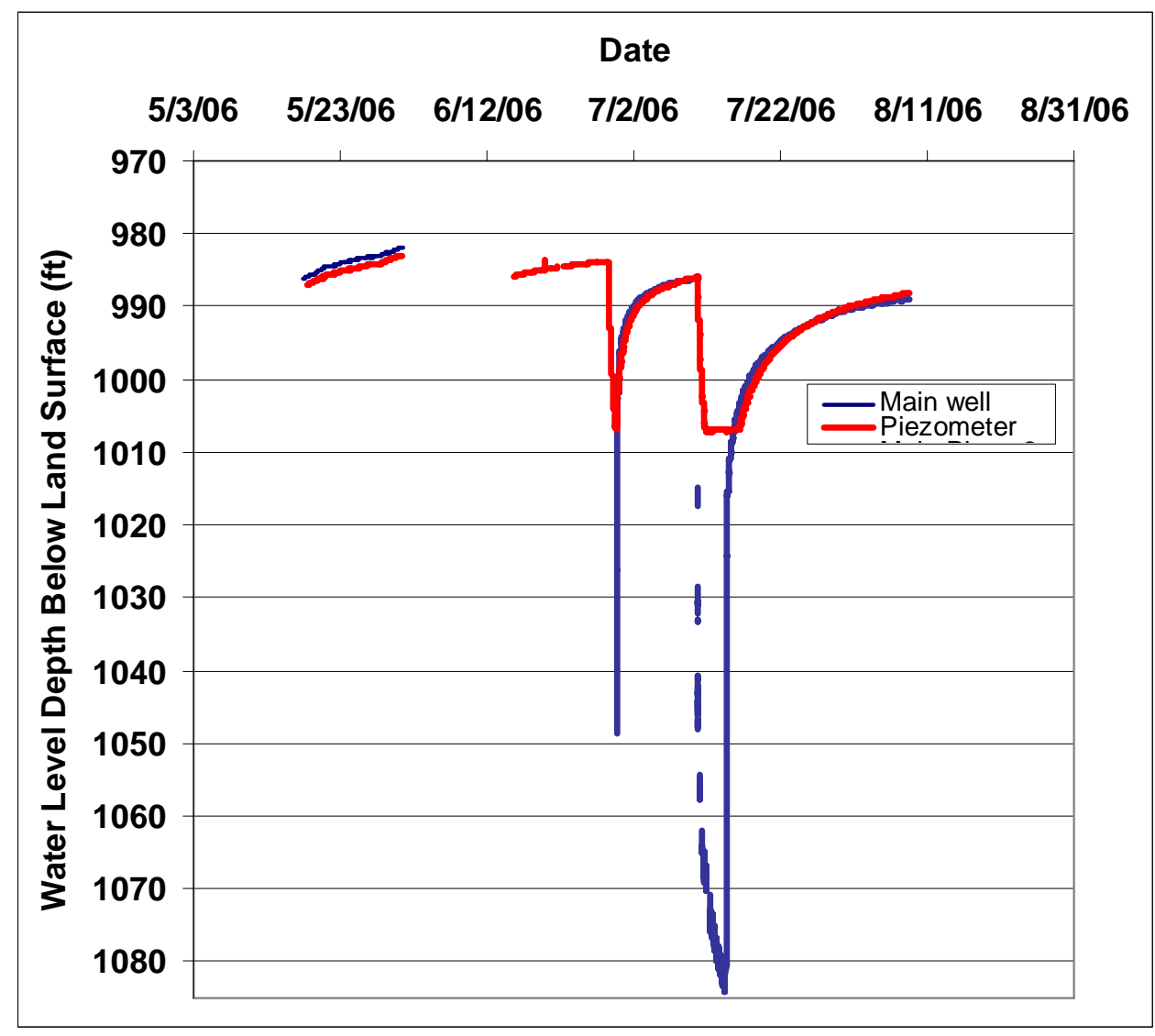

Figure 14. PSA MV-3 water level versus time for main well and piezometer. On June 28 to 29 , the piezometer and main well responded to sampling activities; from July 10 to 14, the piezometer and main wells responded to the aquifer test.

Water level drawdown during pumping of MV-3 is presented in Figure 15. The data collected before 70 minutes are potentially nonrepresentative because the water levels may be influenced by water storage within the well casing (Driscol, 1986). The water levels near the end of the pumping period are selected for interpretation with the Cooper-Jacob methodology (Cooper and Jacob, 1946). The data do not form a strictly linear trend when plotted on a logarithmic time scale. The data collected between 20 and 150 minutes may represent conditions near the well. After 150 minutes of pumping, the water level trend becomes slightly less steep, suggesting an additional hydraulic process (i.e., delayed yield) or additional source of water (i.e., transmissive fractures) was intercepted by the cone of depression. The slope of water level drawdown becomes steeper between 1,070 and 5,440 minutes and these data are believed to be most representative of the overall aquifer. Aquifer properties interpreted by this methodology are included in Table 8 summarizing aquifer testing at well MV-3. 
Table 8. Aquifer properties at PSA MV-3.

\begin{tabular}{|c|c|c|c|c|c|}
\hline Data Set & $\begin{array}{l}\text { Interpretation } \\
\text { Method }\end{array}$ & $\begin{array}{c}\text { Transmissivity } \\
\left(\mathrm{ft}^{2} / \mathrm{d}\right)\end{array}$ & $\begin{array}{c}\text { Confidence } \\
\text { (heuristic) }\end{array}$ & $\begin{array}{c}\text { Water Producing } \\
\text { Zone } \\
(\mathrm{ft})\end{array}$ & $\begin{array}{c}\text { Hydraulic } \\
\text { Conductivity } \\
\text { (ft/d) }\end{array}$ \\
\hline MV-3 Drawdown & Cooper-Jacob & 11.29 & Good & 160 & $7.06 \mathrm{E}-02$ \\
\hline MV-3 Drawdown & $\begin{array}{l}\text { Hantush-Jacob } \\
\text { Leaky Aquifer }\end{array}$ & 10.00 & Moderate & 160 & $6.25 \mathrm{E}-02$ \\
\hline MV-3 Recovery & Cooper-Jacob & 7.78 & Moderate & 160 & $4.86 \mathrm{E}-02$ \\
\hline
\end{tabular}

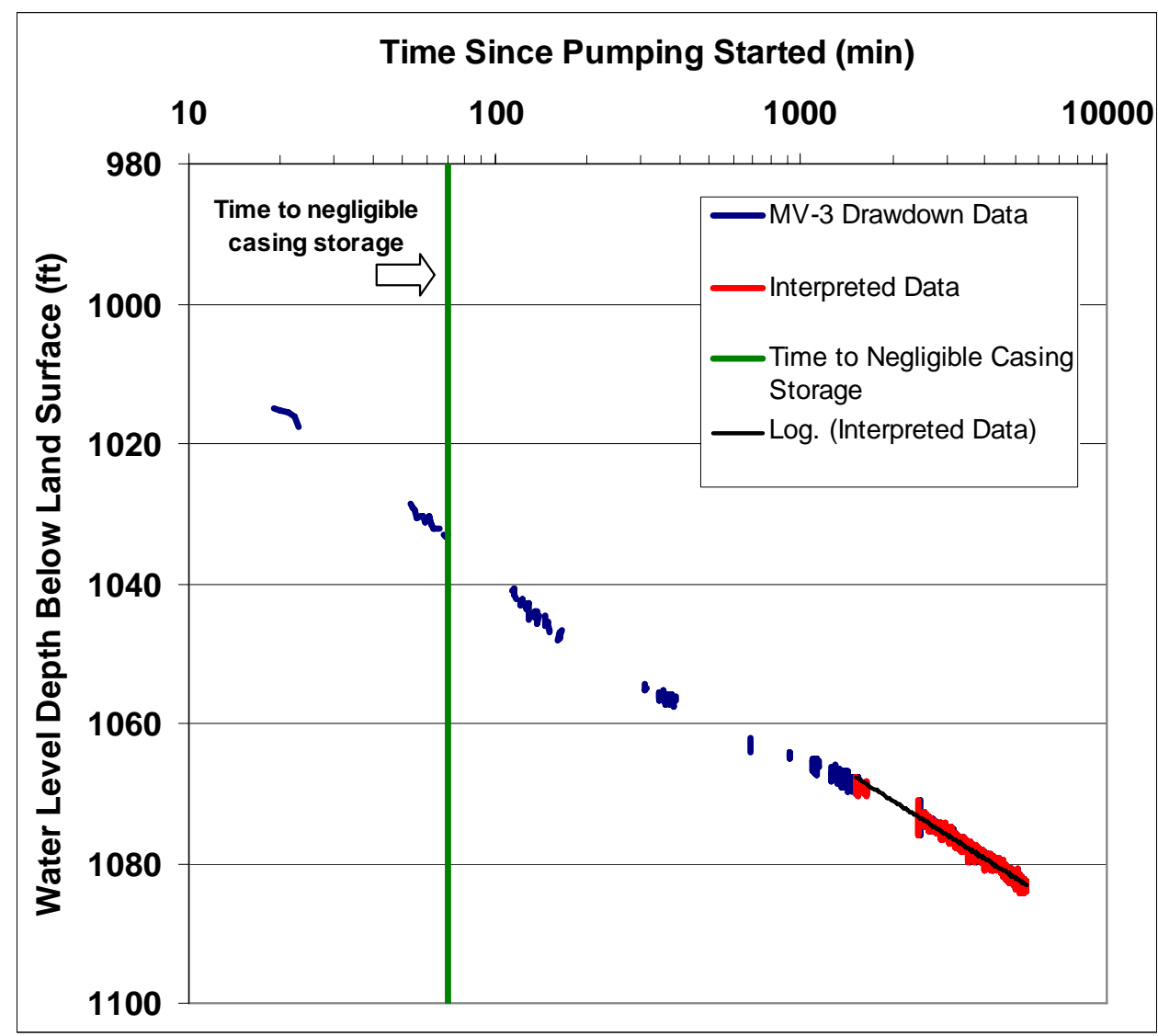

Figure 15. PSA MV-3 water level drawdown during pumping, interpreted by the Cooper-Jacob method.

The drawdown data are also interpreted with the Hantush-Jacob method for leaky aquifers using U.S. Geological Survey software (Halford and Kuniansky, 2002). Figure 16 presents the graph resulting from the use of this interpretation technique. The method is most applicable for data collected at monitoring wells adjacent to the pumping well. However, the water level responses at wells HC-1 and HC-6 to pumping of well MV-3 are indistinct. The water level drawdown data for well MV-3 is interpreted by the Hantush-Jacob method, but the influence of delayed yield to the drawdown curve is minimal. Aquifer properties interpreted by this methodology are included in Table 8 summarizing aquifer testing at well MV-3 


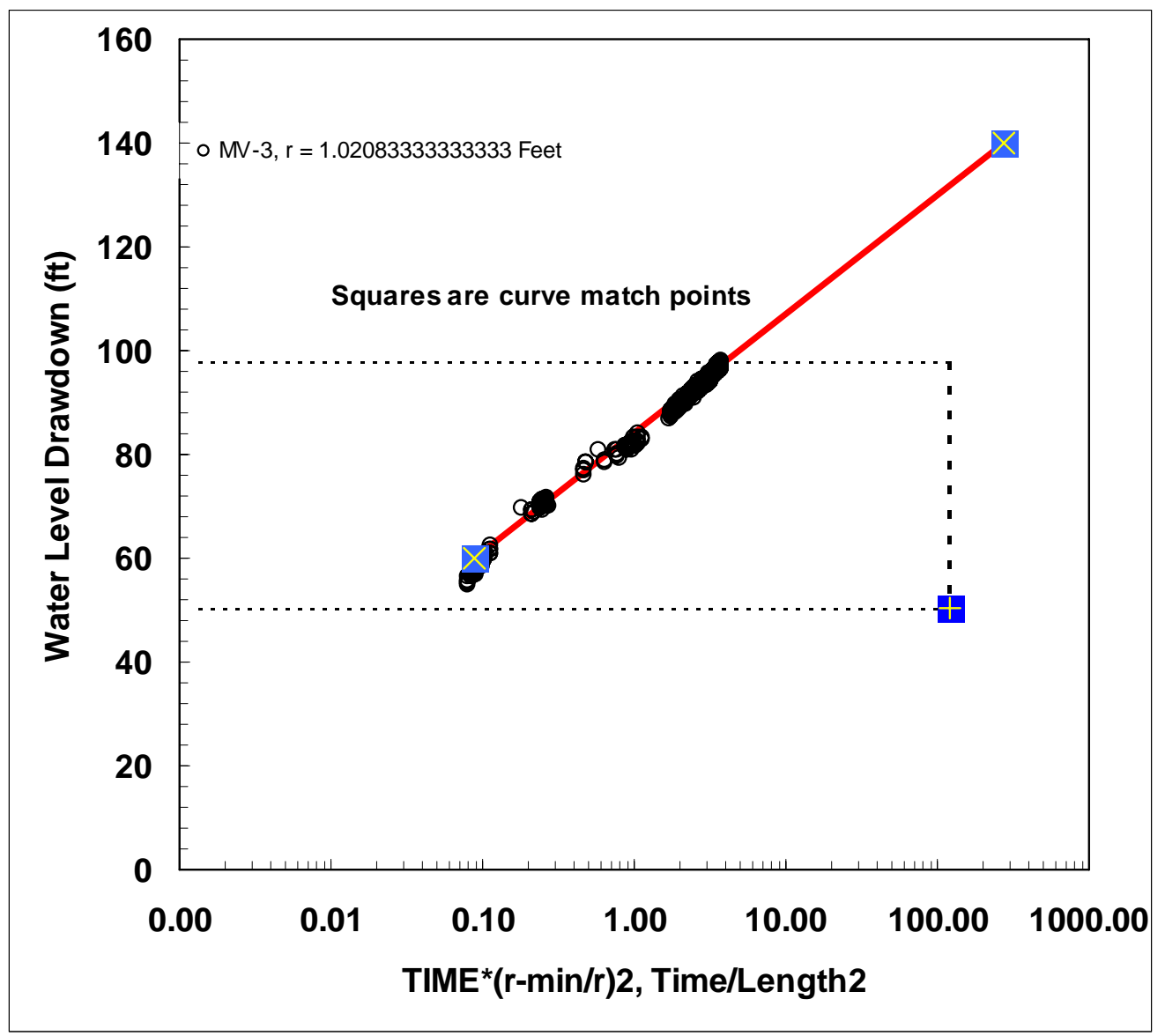

Figure 16. PSA MV-3 water level drawdown during pumping, analyzed by the Hantush-Jacob leaky aquifer method.

Water level recovery following pumping is presented in Figure 17 and interpreted with the Cooper-Jacob methodology. The water level recovery is nearly linear when plotted on a semi-logarithm time scale. The data near the end of the aquifer test (located at the left side of the figure) have a decrease in water level recovery rate followed by an increase in water level recovery rate. This minor trend is suggestive of a process (i.e., delayed yield) that is being replenished toward the end of water level recovery. Therefore, a portion of the recovery before the replenishment process began was selected for interpretation. Aquifer properties interpreted by this methodology are included in Table 8 summarizing aquifer testing at well MV-3. 


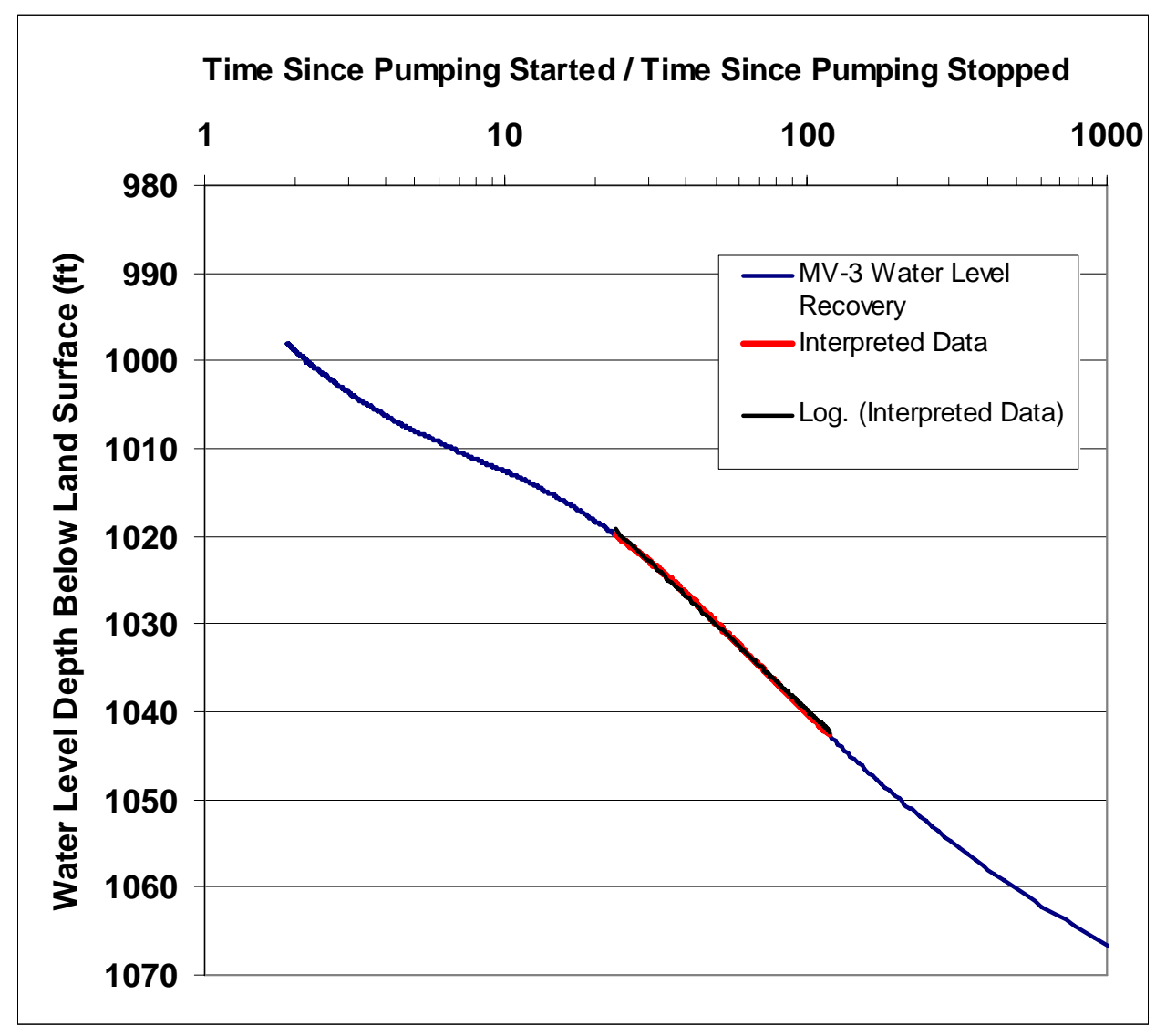

Figure 17. PSA MV-3 water level recovery following pumping analyzed by the Cooper-Jacob method

The interpreted water level drawdown and recovery data from the MV-3 aquifer testing are summarized in Table 8. The calculated aquifer transmissivity is similar for all interpretation methods and data sets. The similar transmissivity values provide confidence that the calculated values are representative of the aquifer. Hydraulic conductivity values are estimated from the calculated transmissivity and the vertical extent of the fractures adjacent to the screened interval in the main well. The fracture interval contributing water to the well is illustrated in Figure 13 and has a vertical thickness of about $160 \mathrm{ft}$. The hydraulic conductivity values are presented in Table 8 . A hydraulic conductivity of $7.06 \mathrm{E}-02 \mathrm{ft} / \mathrm{d}$ is representative of the aquifer.

\section{MV-1 TESTING AND SAMPLING}

Well MV-1 was drilled to a total depth of 1,788 ft; well screen was installed from 1,573 to $1,727 \mathrm{ft}$, specifically targeting a highly fractured area identified from drilling and geophysical log information. The piezometer was screened from 1,337 to 1,397 ft, and was specifically targeted to be above a fault zone (Table 9). A generalized well schematic, including selected geophysical logs, is shown in Figure 18. All geophysical logs are included on a data $\mathrm{CD}$ accompanying this report. 
Table 9. Shoal MV-1 well specifications.

\begin{tabular}{lc}
\hline Northing (m) UTM-NAD27 & $4,339,959.482$ \\
Easting (m) UTM-NAD27 & $380,918.5$ \\
Elevation (AMSL) (m) NAVD 29 & $1,602.5$ \\
Well Total Depth (ft) & $1,788.2$ \\
Well Top of Screen (ft) & $1,572.73$ \\
Well Bottom of Screen (ft) & $1,726.54$ \\
Top of Gravel (ft) & 1,481 \\
Bottom of Gravel (ft) & 1,788 \\
Piezometer Top of Screen (ft) & $1,337.5$ \\
Piezometer Bottom of Screen (ft) & $1,397.5$ \\
Piezometer Top of Gravel (ft) & 1,242 \\
Piezometer Bottom of Gravel (ft) & 1,425 \\
Estimated Wellbore Volume (gal) & 1,326 \\
\hline
\end{tabular}

Well drilling was performed with the dual-tube air foam technique, starting May 8, 2006, and completed May 20, 2006. Airlift development was performed with the drilling rig for approximately 48 hours, and was completed May 22, 2006. Although the well was drilled with air foam, due to wellbore stability concerns, the borehole was filled with drilling mud before well construction. Consequently, this required more well development time to remove the drilling mud from the well. Airlift development was performed until solids were no longer being visibly produced in the discharge water. Final well development was performed with the dedicated submersible sample pump. The well was pumped periodically during the day shifts from June 2 to 14, 2006.

Piezometer development was performed June 4 to 6, 2006, with a pump setting rig using a combination of wireline bailing and airlifting. Production rates varied from a few gallons per minute to a very low flow rate. During the first day of air development, approximately 1,200 gallons of water were produced from the piezometer. However, once the airline was lowered into the piezometer screen, the discharge rate was reduced to almost zero. This was interpreted as air-locking the screen and formation. Water levels appear to have recovered within days after the airlifting was stopped (Figure 19).

Water quality samples were collected after at least three well volumes were purged and field parameters of temperature, electrical conductance, and $\mathrm{pH}$ stabilized. The well volume was assumed to be the wellbore volume plus volume of water in the gravel pack, assuming 30 percent porosity (Table 9). Field measurements of temperature, electrical conductance, and $\mathrm{pH}$ were monitored for stability before sample collection. Analytical results are included in Table 6; samples from previously sampled wells are included for comparison. Major cations and anions, stable isotopes, and radio isotopes are similar to other wells in the area. No analytes indicated radionuclide transport.

An aquifer test was performed from July 25 to August 6, 2006; water levels were continuously monitored with a transducer in the main well and in the piezometer during the drawdown and recovery (Figure 19). 

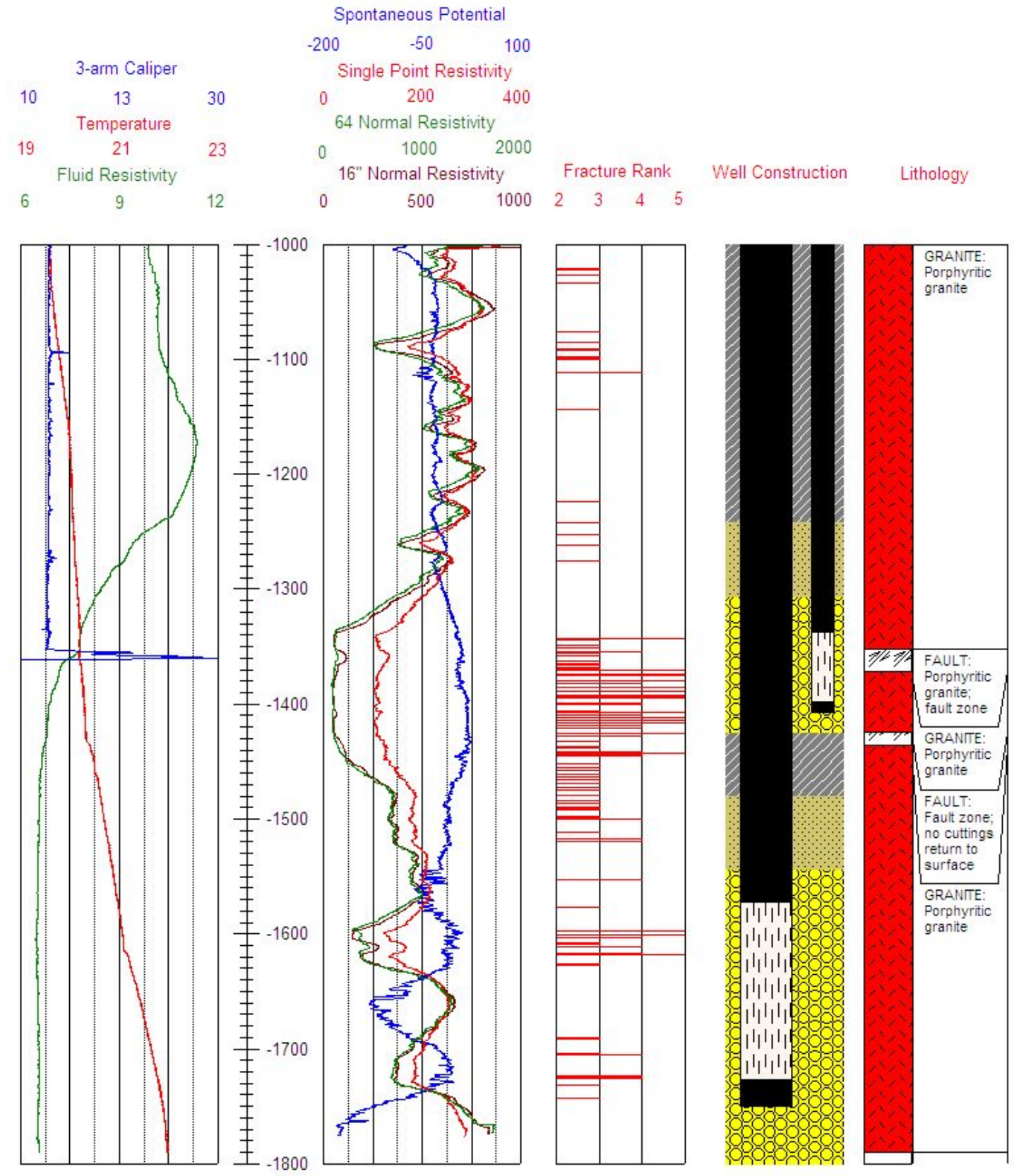

Figure 18. PSA MV-1 generalized well schematic and selected geophysical logs. 


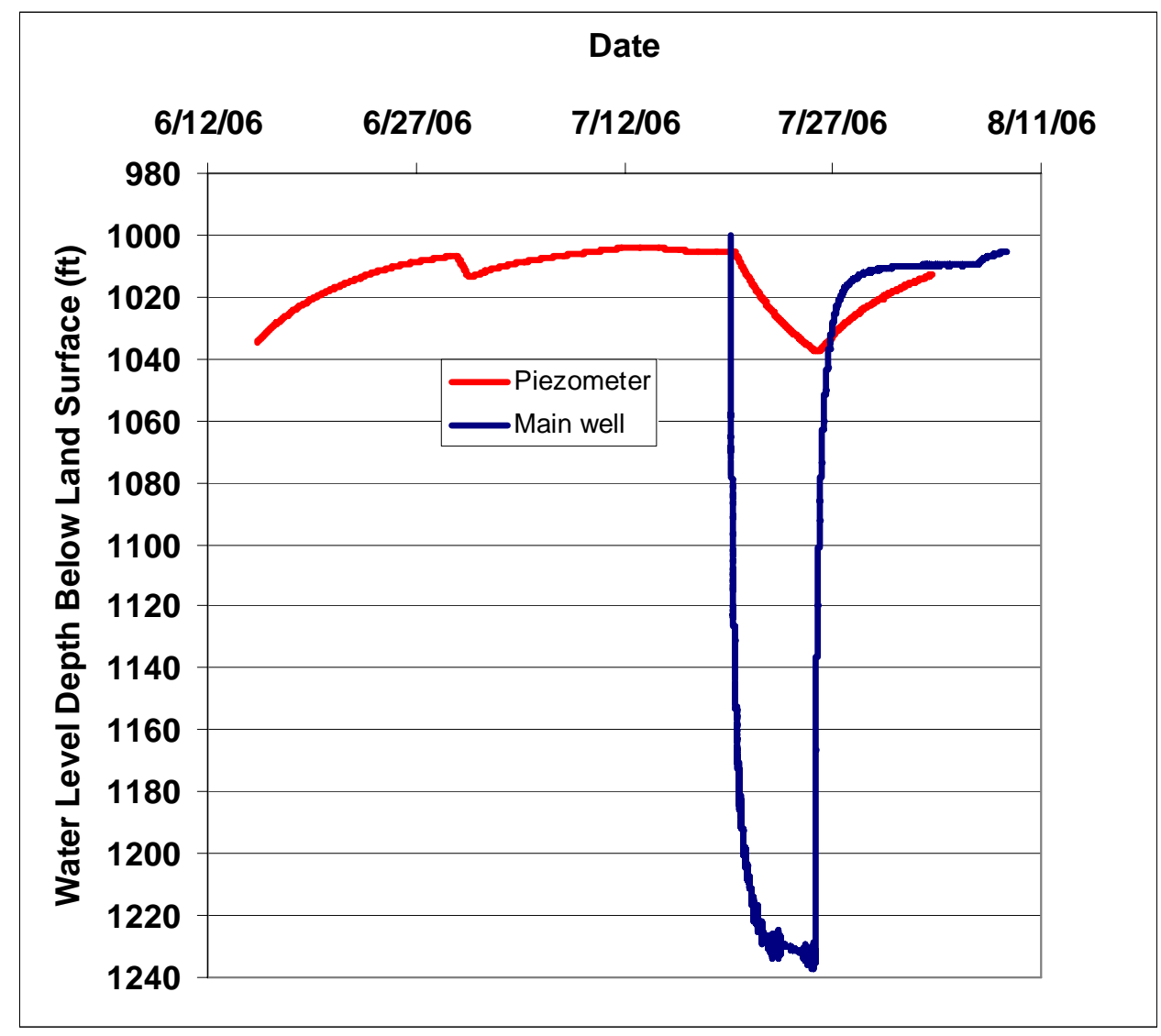

Figure 19. PSA MV-1 water level versus time for main well and piezometer. Early-time data show the piezometer recovery from development activities. On June 29 to 30, the piezometer responded to pumping in the main well during sampling activities, and on July 19 to 25 , the piezometer and main wells responded to the aquifer test.

Water level drawdown during pumping of MV-1 is presented in Figure 20. The data do not form a strictly linear trend when plotted on a logarithmic time scale. The data collected before 200 minutes are potentially nonrepresentative because the water levels are influenced by water storage within the well casing (Driscol, 1986). The water levels after 2,000 minutes of pumping become less steep, suggesting an additional hydraulic process (i.e., delayed yield) or additional source of water (i.e., transmissive fractures) was intercepted by the cone of depression. The data selected for interpretation with the Cooper-Jacob methodology were collected between 200 and 2,000 minutes of pumping (Cooper and Jacob, 1946). Aquifer properties interpreted by this methodology are included in Table 10 summarizing aquifer testing at well MV-1. 
Table 10. Aquifer properties at PSA MV-1.

\begin{tabular}{clcccc}
\hline Data Set & $\begin{array}{c}\text { Interpretation } \\
\text { Method }\end{array}$ & $\begin{array}{c}\text { Transmissivity } \\
\left(\mathrm{ft}^{2} / \mathrm{d}\right)\end{array}$ & $\begin{array}{c}\text { Confidence } \\
(\text { heuristic })\end{array}$ & $\begin{array}{c}\text { Water Producing } \\
\text { Zone } \\
(\mathrm{ft})\end{array}$ & $\begin{array}{c}\text { Hydraulic } \\
\text { Conductivity } \\
(\mathrm{ft} / \mathrm{d})\end{array}$ \\
\hline MV-1 Drawdown & Cooper-Jacob & 2.31 & Good & 160 & $1.44 \mathrm{E}-02$ \\
MV-1 Drawdown & $\begin{array}{l}\text { Hantush-Jacob } \\
\text { Leaky Aquifer }\end{array}$ & 2.00 & Moderate & 160 & $1.25 \mathrm{E}-02$ \\
MV-1 Recovery & Cooper-Jacob & n.a. & Low & -- & -- \\
\hline
\end{tabular}

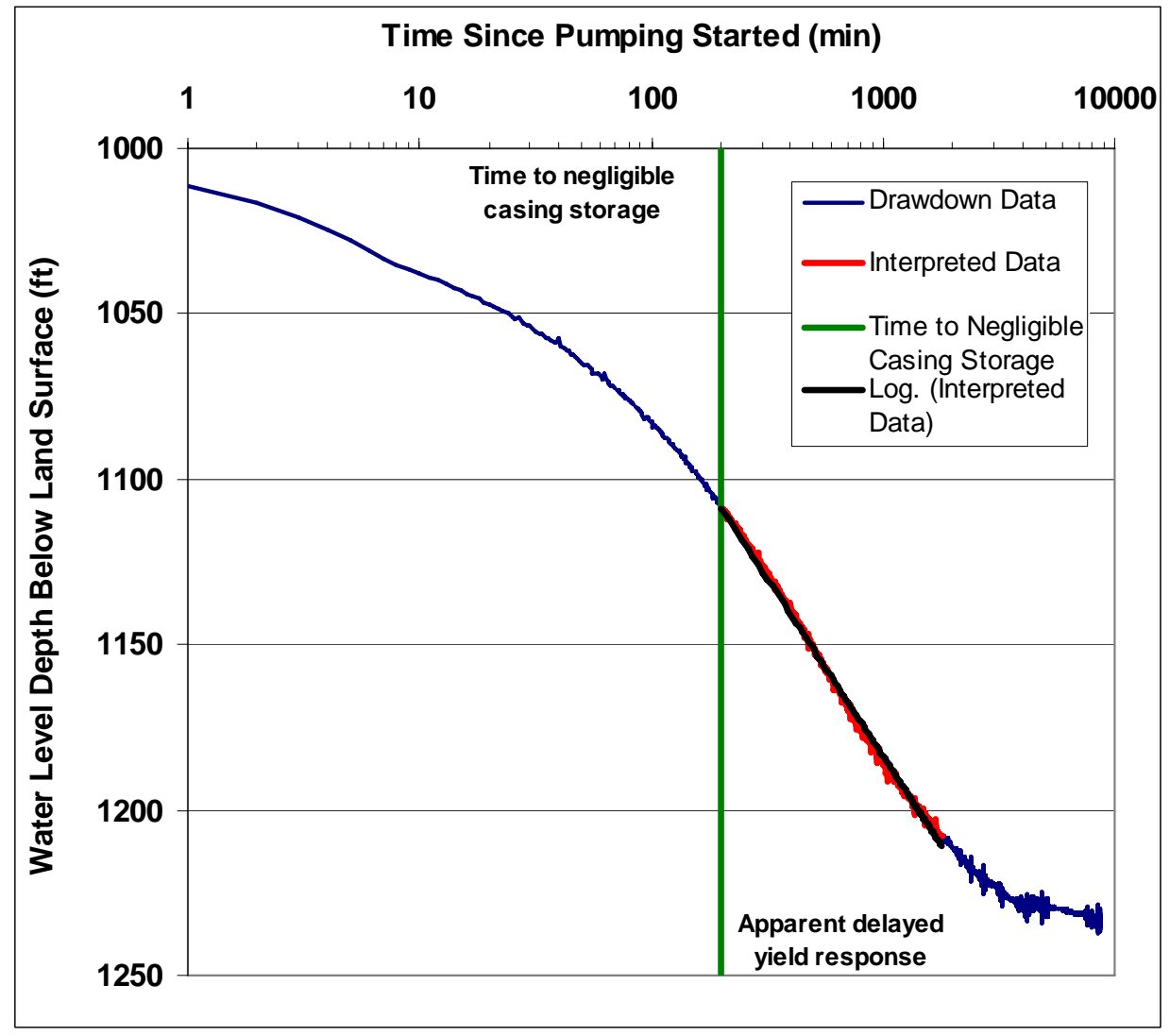

Figure 20. PSA MV-1 water level drawdown during pumping, interpreted by the Cooper-Jacob method

The drawdown data are also interpreted with the Hantush-Jacob method for leaky aquifers using U.S. Geological Survey software (Halford and Kuniansky, 2002). Figure 21 presents a graph resulting from use of this interpretation technique. The method is most applicable for data collected at monitoring wells adjacent to the pumping well. However, the water level response at well HC-6 to pumping of well MV-1 is indistinct. Well HC-1 (Figure 8) apparently responded to pumping of MV-1 with about $1 \mathrm{ft}$ of drawdown. These HC-1 data are linear with time and suggest a process of dewatering a bounded aquifer rather than a typical drawdown response to pumping in an extensive aquifer. The drawdown data from 
HC-1 are not included in the interpretation of aquifer properties for well MV-1. Aquifer properties interpreted by this methodology are included in Table 10 summarizing aquifer testing at well MV-1

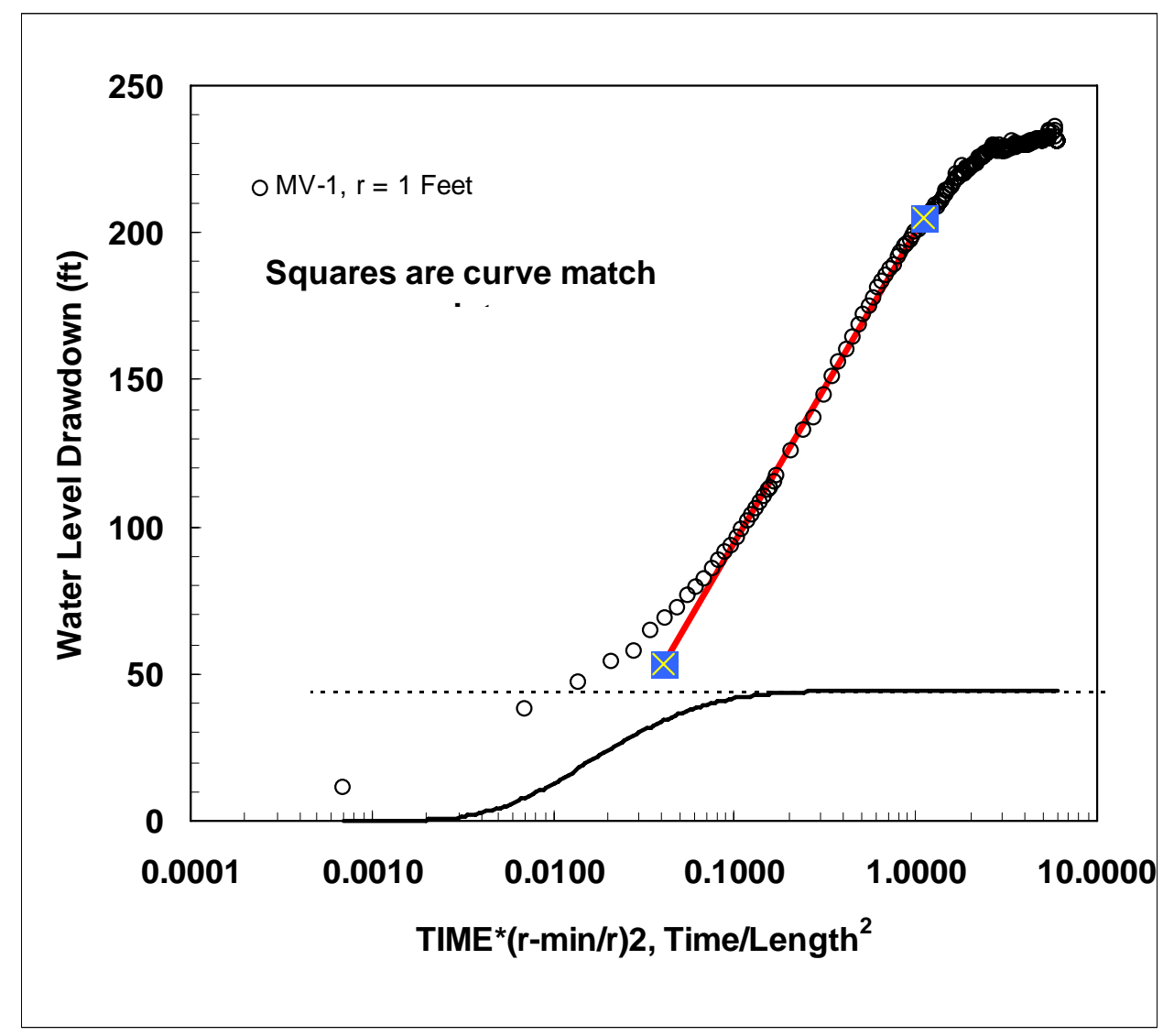

Figure 21. PSA MV-1water level drawdown during pumping, analyzed by the Hantush-Jacob leaky aquifer method.

Water level recovery following pumping is presented in Figures 22a and 22b. The water level recovery is nonlinear when plotted on a logarithmic time scale. The water level recovery trend is unexpected given the drawdown water level response to pumping. Typically, a delayed yield response during pumping is followed in the water level recovery period by a decrease in the water level trend. Between times 10,000 and 100 the recovery rate increases. The recovery curve then changes inflection and has a decreasing trend from time 100 to 1 . The data near the end of the aquifer test are detailed in Figure 22b. These data have a sudden and unexplained increase in water level recovery rate at the end of the test. This suggests that there are processes or events associated with this aquifer test that are not described. The uncertainty in the interpretation of the water level recovery response to pumping suggests that the aquifer transmissivity not be quantified by these data. 


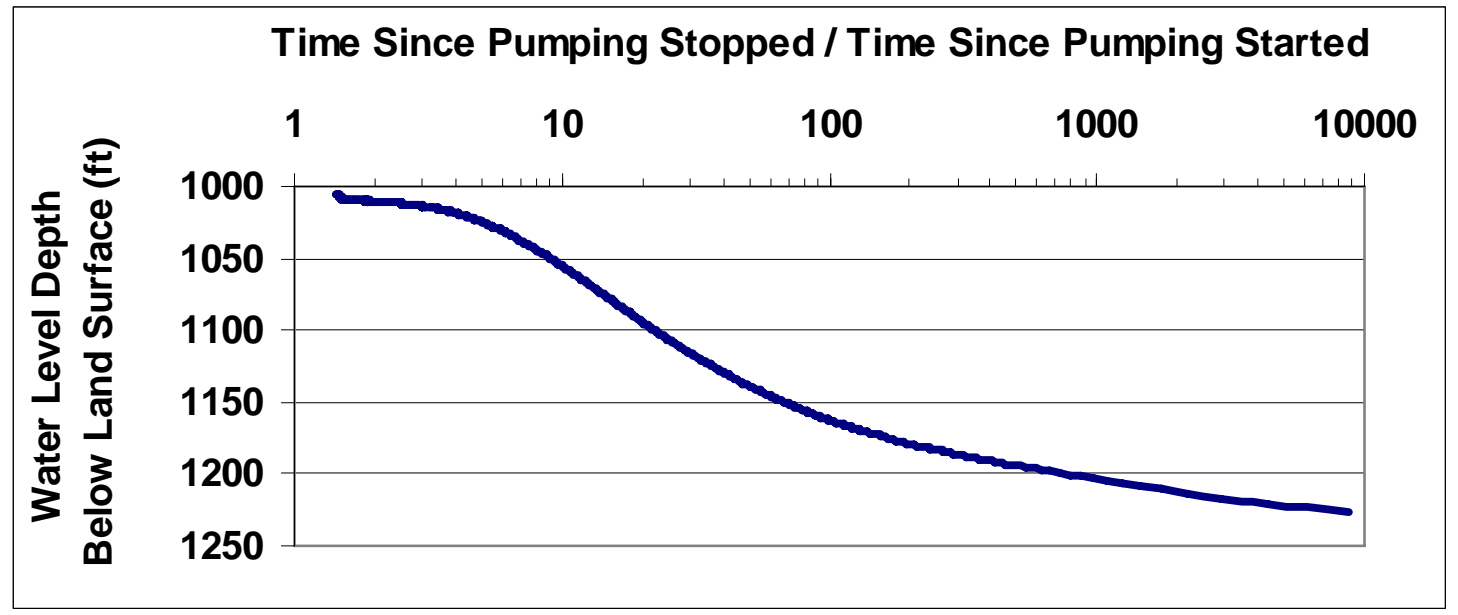

Figure 22a. PSA MV-1 water level recovery following pumping plotted by the Cooper-Jacob method.

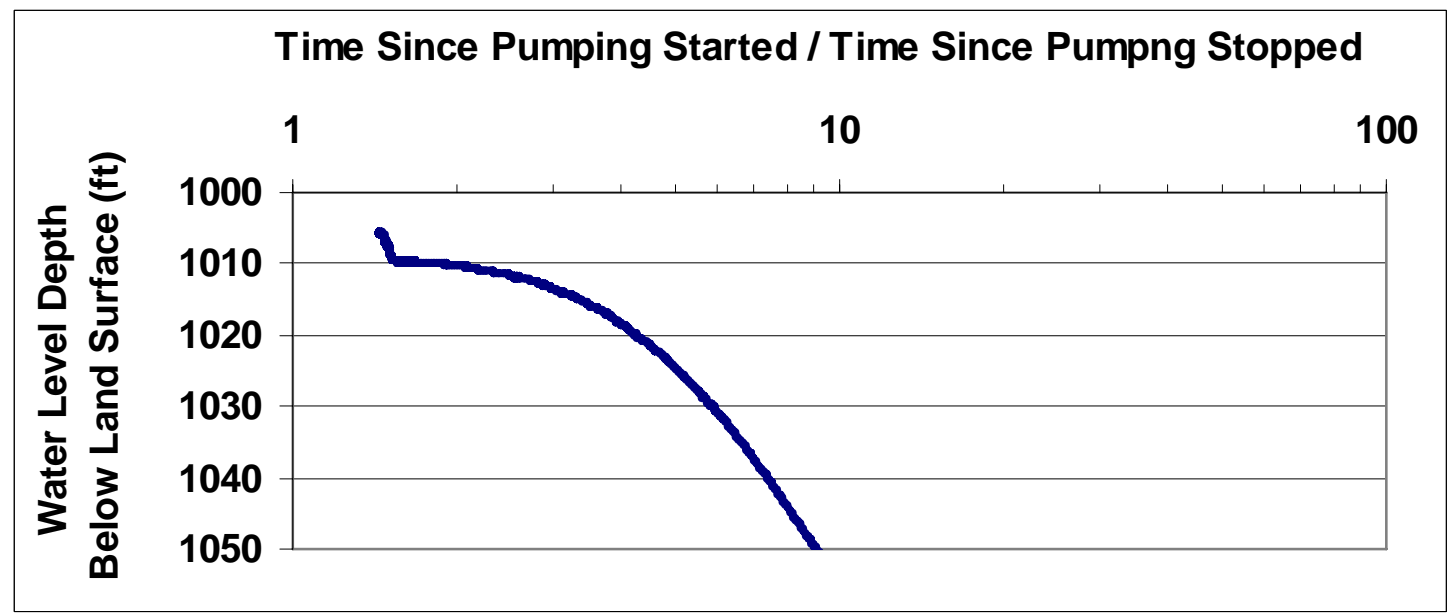

Figure 22b. PSA MV-1 detailed late-time water level recovery following pumping, plotted by the Cooper-Jacob method.

The interpreted water level drawdown and recovery data from the MV-1 aquifer testing are summarized in Table 10. The calculated aquifer transmissivity is similar for the two interpretation methods. The lack of an interpretable water level recovery response reduces confidence that the calculated values are representative of the aquifer. Hydraulic conductivity values are estimated from the calculated transmissivity and the vertical extent of the fractures adjacent to the screened interval in the main well. The fracture interval contributing water to the well is illustrated in Figure 18 and has a vertical thickness of about $160 \mathrm{ft}$. The hydraulic conductivity values are presented in Table 10. A hydraulic conductivity of $1.44 \mathrm{E}-02 \mathrm{ft} / \mathrm{d}$ is representative of the aquifer.

\section{MV-2 TESTING AND SAMPLING}

Well MV-2 was drilled to a total depth of 2,018 ft; well screen was installed from 1,820 to $1,991 \mathrm{ft}$, specifically targeting a highly fractured area identified from drilling and 
geophysical $\log$ information. The piezometer was screened from 1,188 to $1,247 \mathrm{ft}$, and was generally targeted to be near the water table (Table 11). A generalized well schematic, including selected geophysical logs, are shown in Figure 23. All geophysical logs are included on a data $\mathrm{CD}$ accompanying this report.

Table 11. Shoal MV-2 well specifications.

\begin{tabular}{lc}
\hline Northing (m) UTM-NAD27 & $4,340,042.839$ \\
Easting (m) UTM-NAD27 & $380,875.2$ \\
Elevation (AMSL) (m) NAVD 29 & $1,605.27$ \\
Well Total Depth (ft) & $2,018.0$ \\
Well Top of Screen (ft) & $1,819.87$ \\
Well Bottom of Screen (ft) & $1,990.64$ \\
Top of Gravel (ft) & 1,739 \\
Bottom of Gravel (ft) & 2,018 \\
Piezometer Top of Screen (ft) & $1,187.7$ \\
Piezometer Bottom of Screen (ft) & $1,247.2$ \\
Piezometer Top of Gravel (ft) & 1,076 \\
Piezometer Bottom of Gravel (ft) & 1,280 \\
Estimated Wellbore Volume (gal) & 1,463 \\
\hline
\end{tabular}

Well drilling was performed with the dual-tube air foam technique, starting May 23, 2006. Well construction was completed June 9, 2006, and airlift development was performed with the drilling rig for approximately 24 hours, and was completed June 10, 2006. Although the well was drilled with air foam, due to well bore stability concerns the borehole was filled with drilling mud before well construction. Consequently, this required more development time to remove the drilling mud from the well. Airlift development was performed until solids were no longer being produced. Final well development was performed with the dedicated submersible sample pump; the well was pumped periodically during the day shifts from June 10 to 19, 2006.

Piezometer development was performed June 11 to 14, 2006, with a pump setting rig, using a combination of wireline bailing and airlifting; production rates were extremely low. Periodic water level measurements indicate there has been virtually no flow into the well after the tubing was dewatered during development (Table 12). The piezometer screen is completely full of congealed drilling mud and it is likely that this is why water levels are recovering so slowly. Assuming the potentiometric level should be similar in the main well and the piezometer, it may take many years for the piezometer level to fully recover.

Table 12. PSA MV-2 periodic water level measurements.

\begin{tabular}{llcc}
\hline Site & Date & Hrs & Depth (ft BLS) \\
\hline MV-2 piezometer & $6 / 21 / 2006$ & $18: 34$ & $1,143.25$ \\
MV-2 piezometer & $7 / 25 / 2006$ & $16: 10$ & $1,139.8$ \\
MV-2 main well & $7 / 25 / 2006$ & $15: 50$ & $1,014.4$ \\
\hline
\end{tabular}

Water quality samples were collected after at least three well volumes were purged and field parameters stabilized. The well volume was assumed to be the wellbore volume plus volume of water in the gravel pack, assuming 30 percent porosity (Table 11). Field 
measurements of temperature, electrical conductance, and $\mathrm{pH}$ were monitored for stability before sample collection. Analytical results are included in Table 6; historic samples from previously sampled wells are included for comparison. Major cations and anions, stable isotopes, and radio isotopes are similar to other wells in the area. No analytes were found to indicate radionuclide transport.

An aquifer test was performed from July 25 to August 6, 2006; water levels were continuously monitored with a transducer in the main well during the drawdown and recovery (Figure 24) (no transducer was installed in the piezometer).
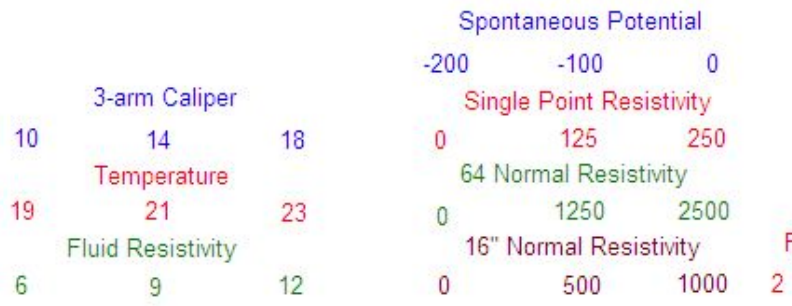

.

(1)

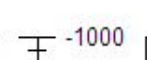

$$
\text { - }
$$
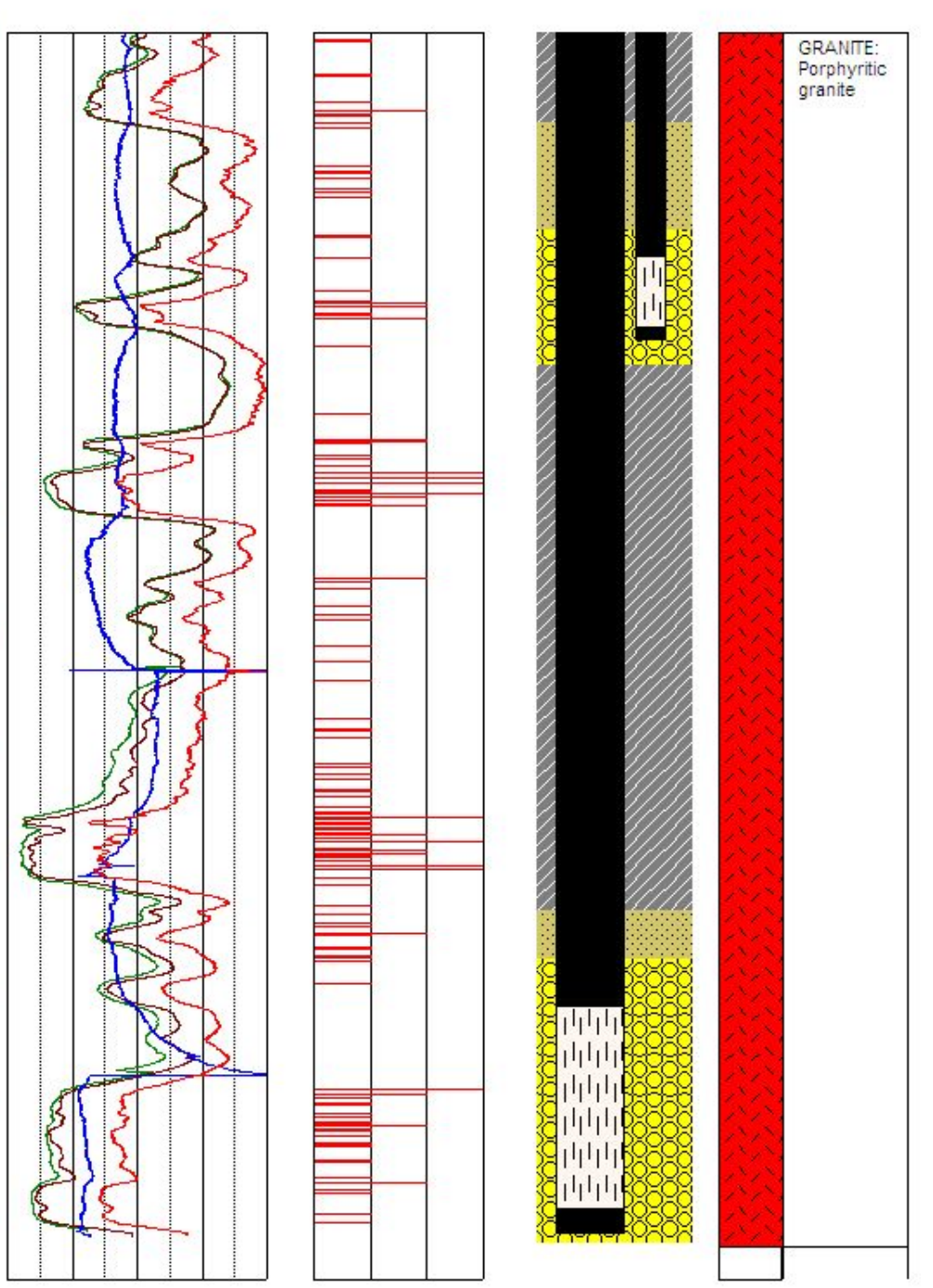

Figure 23. PSA MV-2 generalized well schematic and selected geophysical logs. 


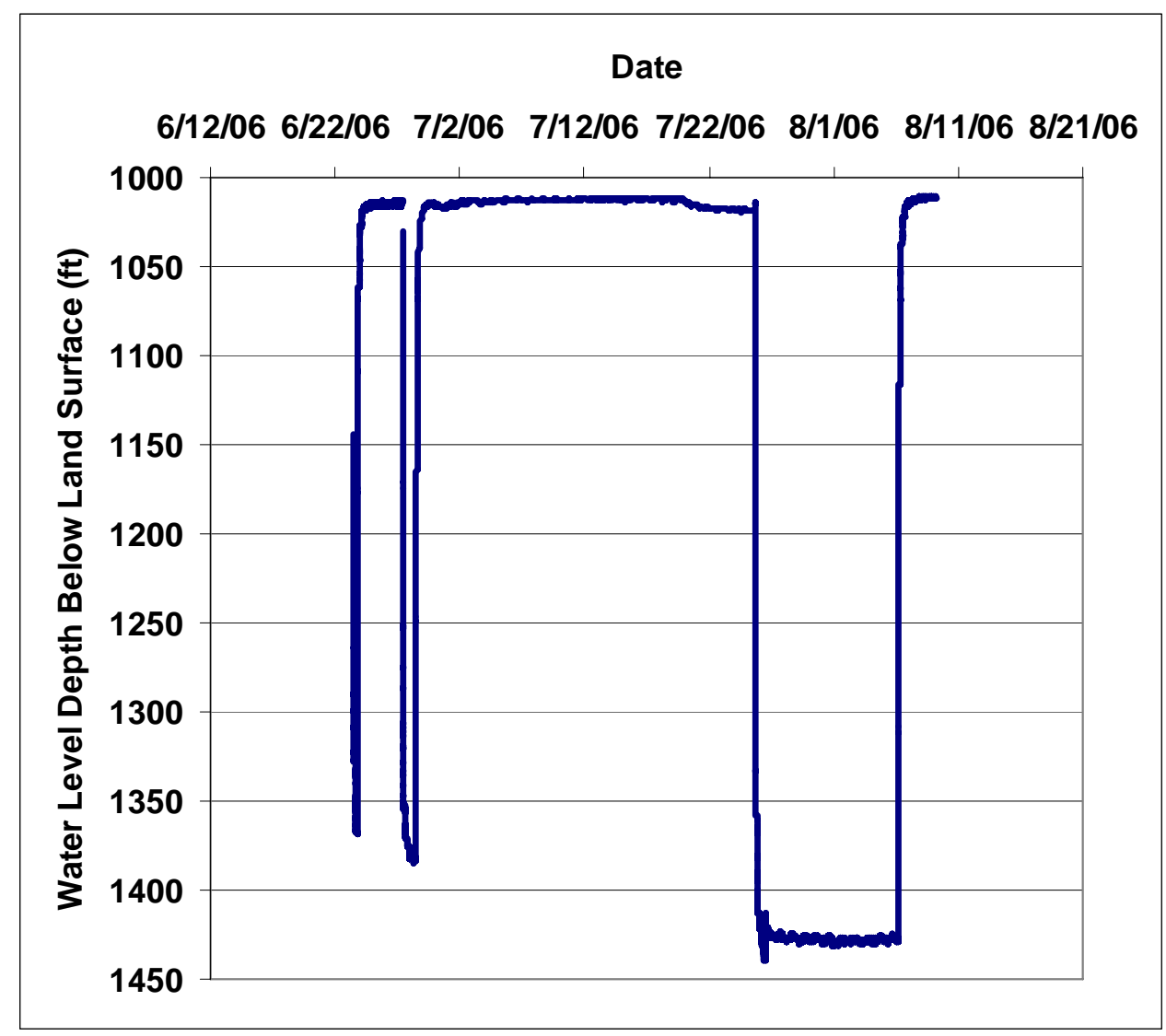

Figure 24. PSA MV-2 water level versus time for main well. Early-time data show the recovery from development activities. On June 27 to 28, the well responded to pumping in during sampling activities, and on July 25 to August 6, the main wells responded to the aquifer test.

Water level drawdown during pumping of MV-2 is presented in Figure 25. The data do not always form a linear trend when plotted on a logarithmic time scale. The data collected before 1,100 minutes are potentially nonrepresentative because of the water levels are influenced by water storage within the well casing (Driscol, 1986). The water level trend after 1,100 minutes of pumping becomes much less steep, suggesting a dominant additional hydraulic process (i.e., delayed yield) or additional source of water (i.e., transmissive fractures) was intercepted by the cone of depression. The data selected for interpretation with the Cooper-Jacob methodology are between 1,100 and 1,267 minutes of pumping (Cooper Jacob, 1946). These data may be influenced by a delayed-yield process and accepted for interpretation of transmissivity with caution. Aquifer properties interpreted by this methodology are included in Table 13 summarizing aquifer testing at well MV-2. 
Table 13. Aquifer properties at PSA MV-2.

\begin{tabular}{llccccc}
\hline \multicolumn{1}{c}{ Data Set } & $\begin{array}{c}\text { Interpretation } \\
\text { Method }\end{array}$ & $\begin{array}{c}\text { Transmissivity } \\
\left(\mathrm{ft}^{2} / \mathrm{d}\right)\end{array}$ & $\begin{array}{c}\text { Storativity } \\
\left(\mathrm{d}^{\prime} \text { less }\right)\end{array}$ & $\begin{array}{c}\text { Confidence } \\
(\text { heuristic })\end{array}$ & $\begin{array}{c}\text { Water Producing } \\
\text { Zone } \\
(\mathrm{ft})\end{array}$ & $\begin{array}{c}\text { Hydraulic } \\
\text { Conductivity } \\
(\mathrm{ft} / \mathrm{d})\end{array}$ \\
\hline MV-2 Drawdown & Cooper-Jacob & 57.57 & n.a. & Moderate & 120 & $4.80 \mathrm{E}-01$ \\
MV-2 Drawdown & $\begin{array}{l}\text { Hantush-Jacob } \\
\text { Leaky Aquifer }\end{array}$ & 0.70 & n.a. & Very Low & -- & -- \\
MV-2 Recovery & Cooper-Jacob & 27.48 & n.a. & Low & 120 & $2.29 \mathrm{E}-01$ \\
HC-1 Drawdown & Cooper-Jacob & 57.79 & $2.14 \mathrm{E}-04$ & Good & 120 & $4.82 \mathrm{E}-01$ \\
HC-1 Recovery & Cooper-Jacob & 109.79 & n.a. & Good & 120 & $9.15 \mathrm{E}-01$ \\
\hline
\end{tabular}

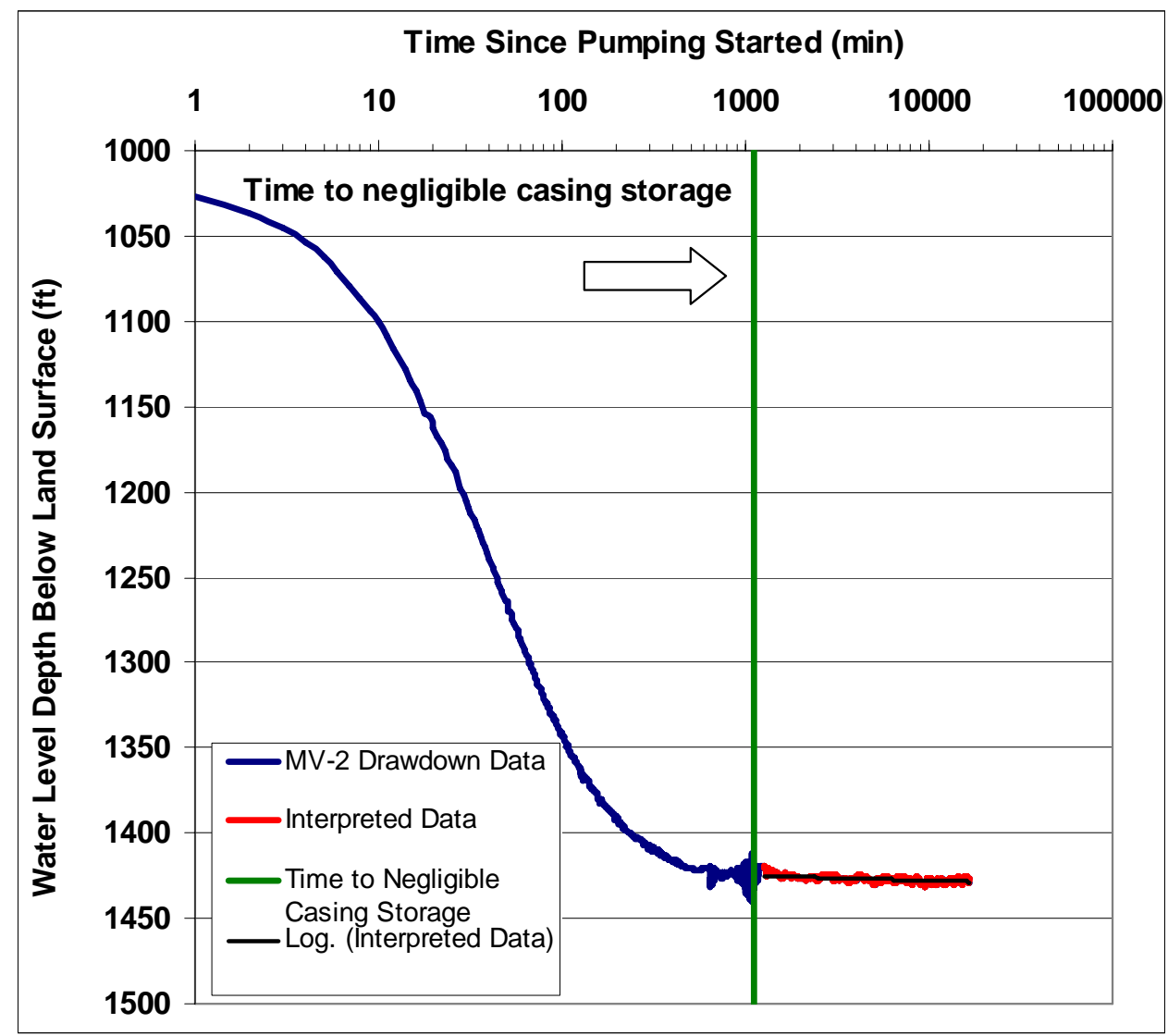

Figure 25. PSA MV-2 water level drawdown during pumping, interpreted by the Cooper-Jacob method.

The drawdown data are also interpreted with the Hantush-Jacob method for leaky aquifers using U.S. Geological Survey software (Halford and Kuniansky, 2002). Figure 26 presents the resulting graph using this interpretation technique. The method is most applicable for data collected at monitoring wells adjacent to the pumping well. However, the water level response at well $\mathrm{HC}-6$ to pumping at MV-2 is indistinct. Well HC-1 responded to pumping of MV-2 with about $4 \mathrm{ft}$ of drawdown. The drawdown at well HC-1 is included as the red line near the bottom of the figure. The data from well $\mathrm{HC}-1$ do not plot as a curve 
having a similar slope to MV-2. Aquifer properties interpreted by this methodology are suspected of being nonrepresentative because the HC-1 data do not plot near the MV-2 data. The results of the leaky aquifer methodology are included in Table 13 summarizing aquifer testing at well MV-2.

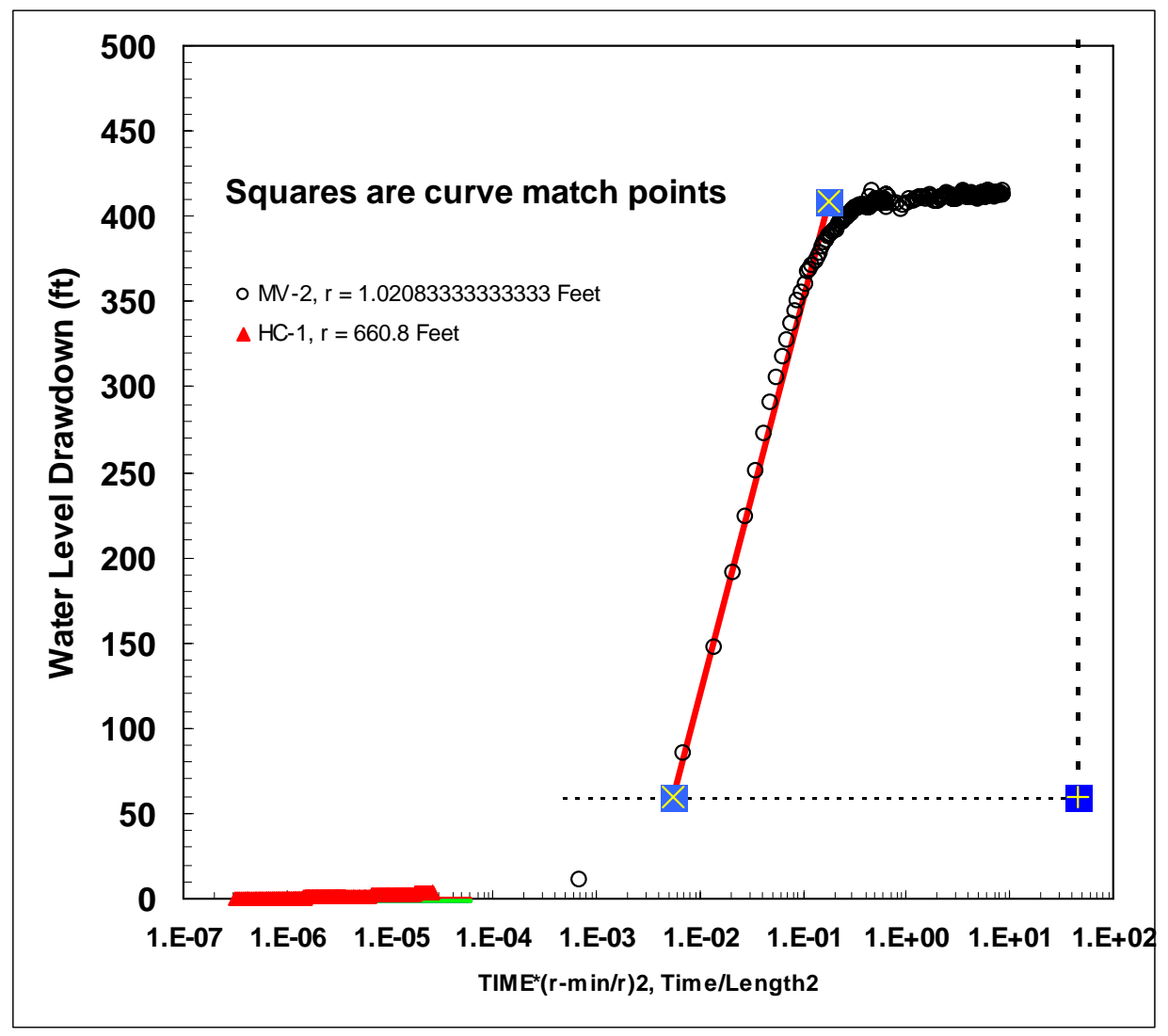

Figure 26. PSA MV-2 water level drawdown during pumping, analyzed by the Hantush-Jacob leaky aquifer method.

The water level drawdown at well HC-1 was also interpreted by the Cooper Jacob methodology. The water level drawdown with time is presented in Figure 27. The figure shows a linear water level trend after 400 minutes of pumping when plotted with a logarithmic time axis. The transmissivity calculated from these data is believed to be representative of the aquifer. The water level response to pumping at $\mathrm{HC}-1$ also provides the information necessary to calculate an aquifer storativity (Cooper and Jacob, 1946). The aquifer properties are presented in Table 13. 


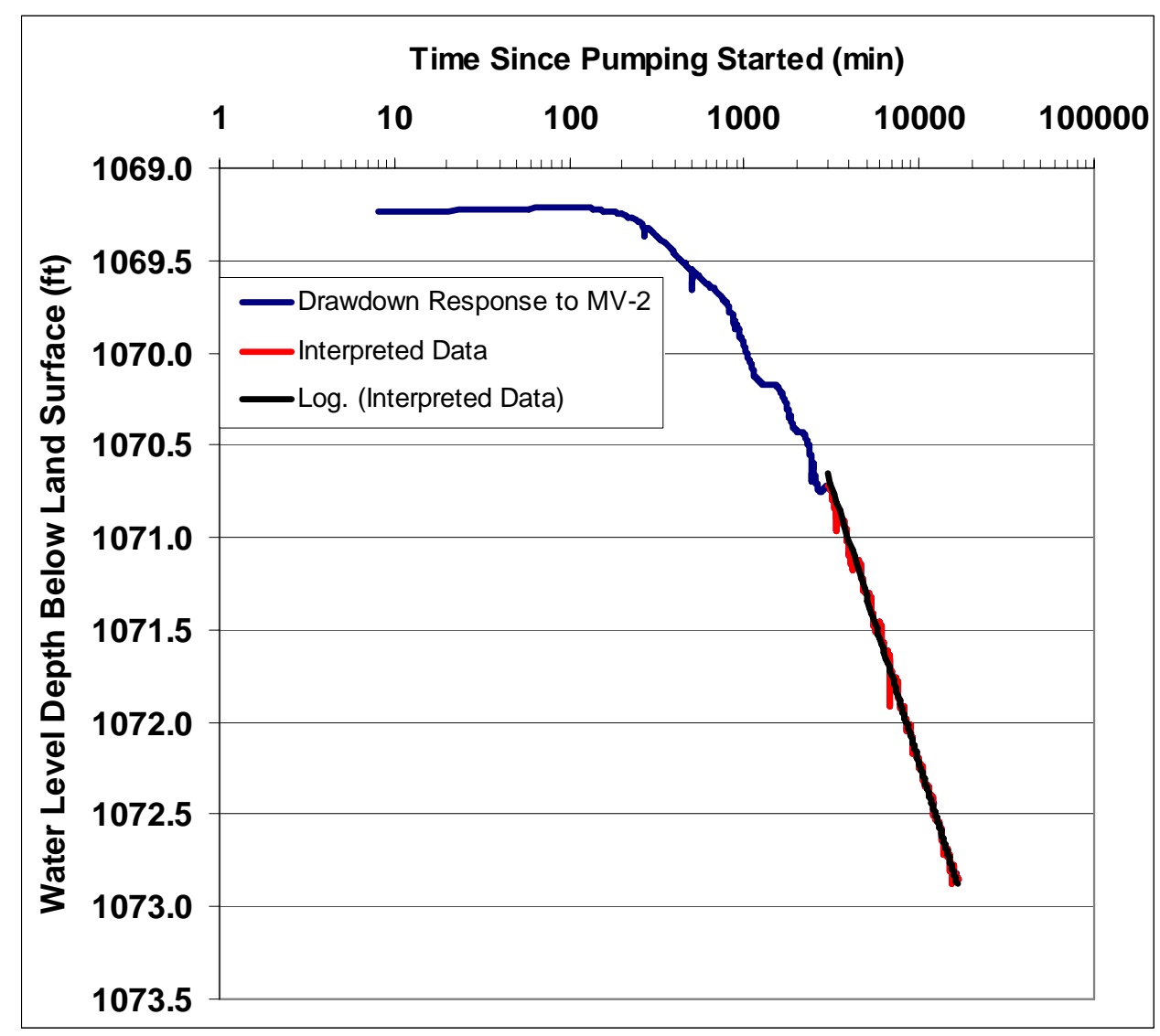

Figure 27. PSA HC-1 water level drawdown following pumping in well MV-2, plotted by the Cooper-Jacob method.

Water level recovery following pumping is presented in Figure 28. The water level recovery is nonlinear when plotted on a logarithmic time scale. The data at the end of the test (i.e., at time 20 to 5) establish a linear trend. However, a time period near the middle of the test (i.e., 1,000 to 100) could also be analyzed. Interpretation of these recovery data is included in the analyses, but has a lower confidence than other data sets for the MV-2 aquifer test. 


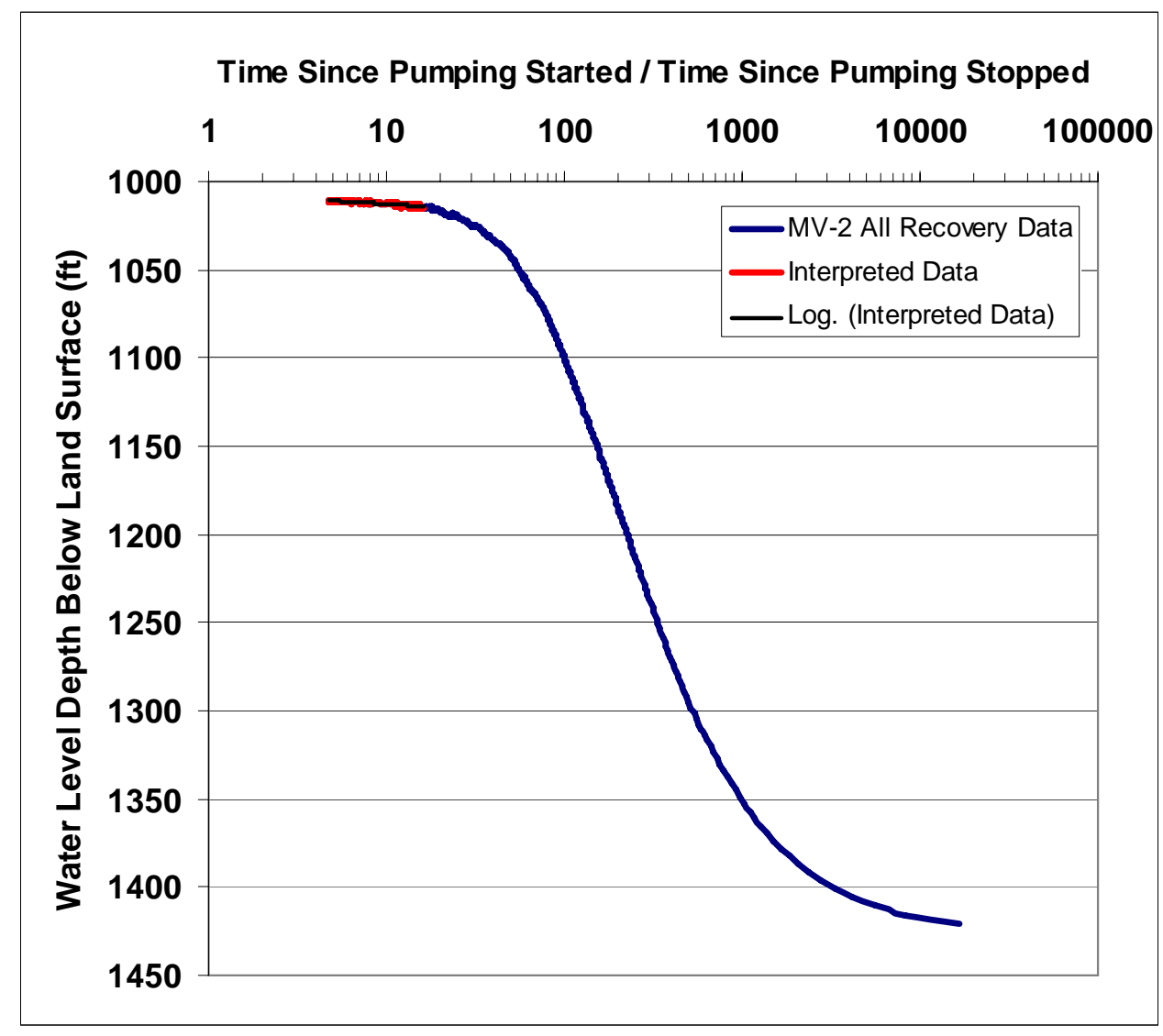

Figure 28. PSA MV-2 water level recovery following pumping, analyzed by the Cooper-Jacob method.

The water level recovery at well $\mathrm{HC}-1$ from pumping at well MV-2 is presented in Figure 29. The data show a linear water level response when plotted on a logarithmic time axis. When the recovery trend is extended to the initial static water level of 1,069.25 $\mathrm{ft}$, the trend is displaced to the left, indicating aquifer dewatering took place during the test. The recovery data at $\mathrm{HC}-1$ from pumping at MV-2 are the only recovery data sufficiently linear when plotted according to the Cooper and Jacob method to evaluate aquifer dewatering/recharge aspects. 


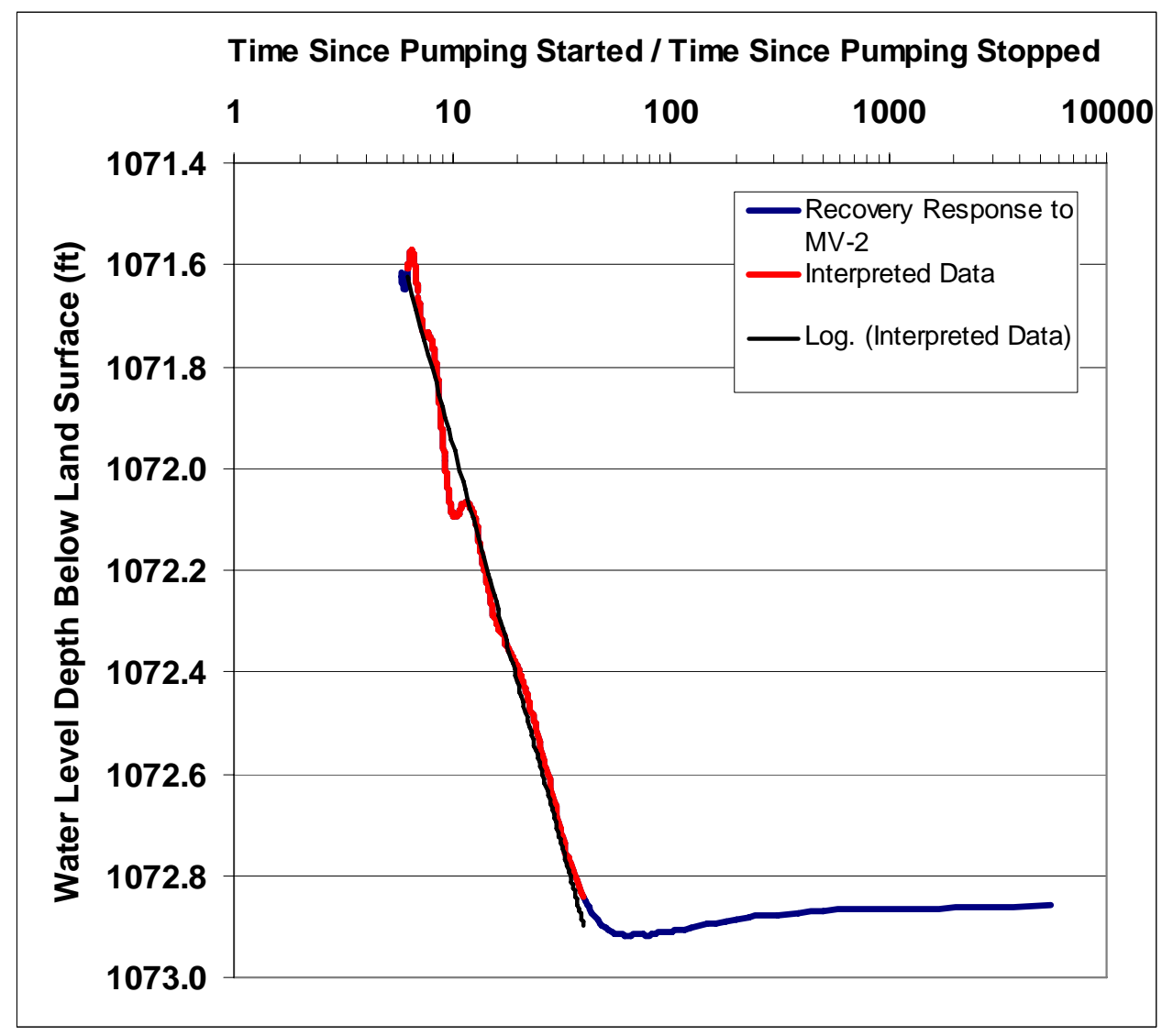

Figure 29. PSA HC-1 water level recovery following MV-2 pumping, analyzed by the Cooper-Jacob method.

The interpreted water level drawdown and recovery data from the MV-2 aquifer testing are summarized in Table 13. The calculated aquifer transmissivity is similar for drawdown at wells MV-2 and HC-1. This adds confidence that those calculated values of transmissivity are representative of the aquifer. The calculated transmissivity values for the recovery data have a lower confidence. Hydraulic conductivity values are estimated from the calculated transmissivity and the vertical extent of the fractures adjacent to the screened interval in the main well. The fracture interval contributing water to the well is illustrated in Figure 23 and has a vertical thickness of about $120 \mathrm{ft}$. The hydraulic conductivity values are presented in Table 13. A hydraulic conductivity of $4.82 \mathrm{E}-01 \mathrm{ft} / \mathrm{d}$ is representative of the aquifer.

\section{SUMMARY AND FUTURE WORK}

Three wells were drilled and constructed during 2006 at the Project Shoal Area. These wells, MV-1, MV-2, and MV-3, are providing information for groundwater model validation and serving as long-term monitoring locations. Each well is completed in a fractured granite aquifer at depths ranging from 1,650 to 2,000 ft. A piezometer is also completed adjacent to each well to provide access for monitoring the water table elevation. 
Geologic data are available in the form of geologist's logs, geophysical logs, and video logs. Aquifer tests have been conducted, water levels monitored, and water samples collected and analyzed. The data are being analyzed in the context of the numerical groundwater flow and transport model. The model validation process, including evaluation of data relative to model predictions, will be reported separately.

Future monitoring will include tracking water levels in the wells and piezometers, and collection and analysis of groundwater samples, per the plan approved in the CADD/CAP. Stable, equilibrated hydraulic head values need to be established, and natural fluctuations in head due to barometric pressure changes and earth tides need to be quantified, for proper interpretation of long-term water level trends.

\section{REFERENCES}

Borg, I.Y., R. Stone, H.B. Levy, and L.D. Ramspott, 1976. Information Pertinent to the Migration of Radionuclides in Ground Water at the Nevada Test Site Part 1: Review and Analysis of Existing Information. UCRL-52078 pt.1, Lawrence Livermore National Laboratory, 216p.

Cooper, H.H. Jr. and C.E. Jacob, 1946. A generalized graphical method for evaluating formation constants and summarizing well-field history. Transactions, American Geophysical Union 27:526-34.

Driscoll, F.G., 1986. Groundwater and Wells, Second Edition, Johnson Division, St. Paul, Minnesota.

Gardner, M. and W. Nork, 1970. Evaluation of the Project Shoal Site, Fallon, Nevada, for Disposition, Including Identification of Restrictions, Part I. Palo Alto, CA. Teledyne Isotopes. $42 \mathrm{p}$.

Halford, K.J. and E.L. Kuniansky, 2002. Documentation of Spreadsheets for the Analysis of Aquifer-Test and Slug-Test Data, Open-File Report 02-197, U.S. Geological Survey.

Hardman, G. and H.G. Mason, 1949. Irrigated lands of Nevada. Nevada University Agr. Sta. Bulletin 183, 56 pp.

Hassan, A.E., 2005. Long-term Monitoring Plan for the Shoal Underground Nuclear Test. Desert Research Institute, Division of Hydrologic Sciences Publication No. 45210, 56 p.

Hazelton-Nuclear Science Corp., 1965. Post-Shot Hydrologic Safety, Project Shoal Final Report. U.S. Atomic Energy Commission, Vela Uniform Project Shoal, VUF-1014, 50 p.

IT Corporation, 2000. 1999 Well Installation Report, Project Shoal Area, Churchill County, Nevada. Prepared for U.S. Department of Energy, Nevada Operations Office. Las Vegas, Nevada, ITLV/13052-097, variable paging.

Maxey, G. and T. Eakin, 1949. Groundwater in the White River Valley, White Pine, Nye and Lincoln Counties, Nevada. Water Resources Bulletin. Vol 8. Carson City, Nevada: State of Nevada, Office of the State Engineer, $59 \mathrm{p}$. 
Pohll, G., J. Chapman, A. Hassan, C. Papelis, R. Andricevic, and C. Shirley, 1998. Evaluation of Groundwater Flow and Transport at the Shoal Underground Nuclear Test: An Interim Report. Desert Research Institute, Water Resources Center Publication No. 45162.

Pohlmann, K., G. Pohll, J. Chapman, A.E. Hassan, R. Carroll, and C. Shirley, 2004. Modeling to Support Groundwater Contaminant Boundaries for the Shoal Underground Nuclear Test. Desert Research Institute, Division of Hydrologic Sciences Publication No. 45184.

U.S. Atomic Energy Commission, 1964. Project Manager's Report Project Shoal. Nevada Operations Office Report NVO-11, 82 p.

U.S. Atomic Energy Commission, 1970. Site Disposal Report, Fallon Nuclear Test Site (Shoal): Churchill County, Nevada, NVO-73, 40 p.

U.S. Department of Energy, 1998. Corrective Action Investigation Plan for Corrective Action Unit 447: Project Shoal Area, Nevada Subsurface Site. Nevada Operations Office, Environmental Restoration Division, DOE/NV--513, 71 p.

U.S. Department of Energy (DOE), 2000. United States Nuclear Tests July 1945 through September 1992. Nevada Operations Office report DOE/NV--209-Rev 15, 162 p.

U.S. Department of Energy (DOE), 2006. Well Completion Report for Corrective Action Unit 447, Project Shoal Area, Churchill County, Nevada. Rev. 0, DOE/NV--1166, 51 p. 
THIS PAGE INTENTIONALLY LEFT BLANK 


\section{APPENDIX: PHOTOGRAPHS OF THE PSA WELL HEAD COMPLETIONS}

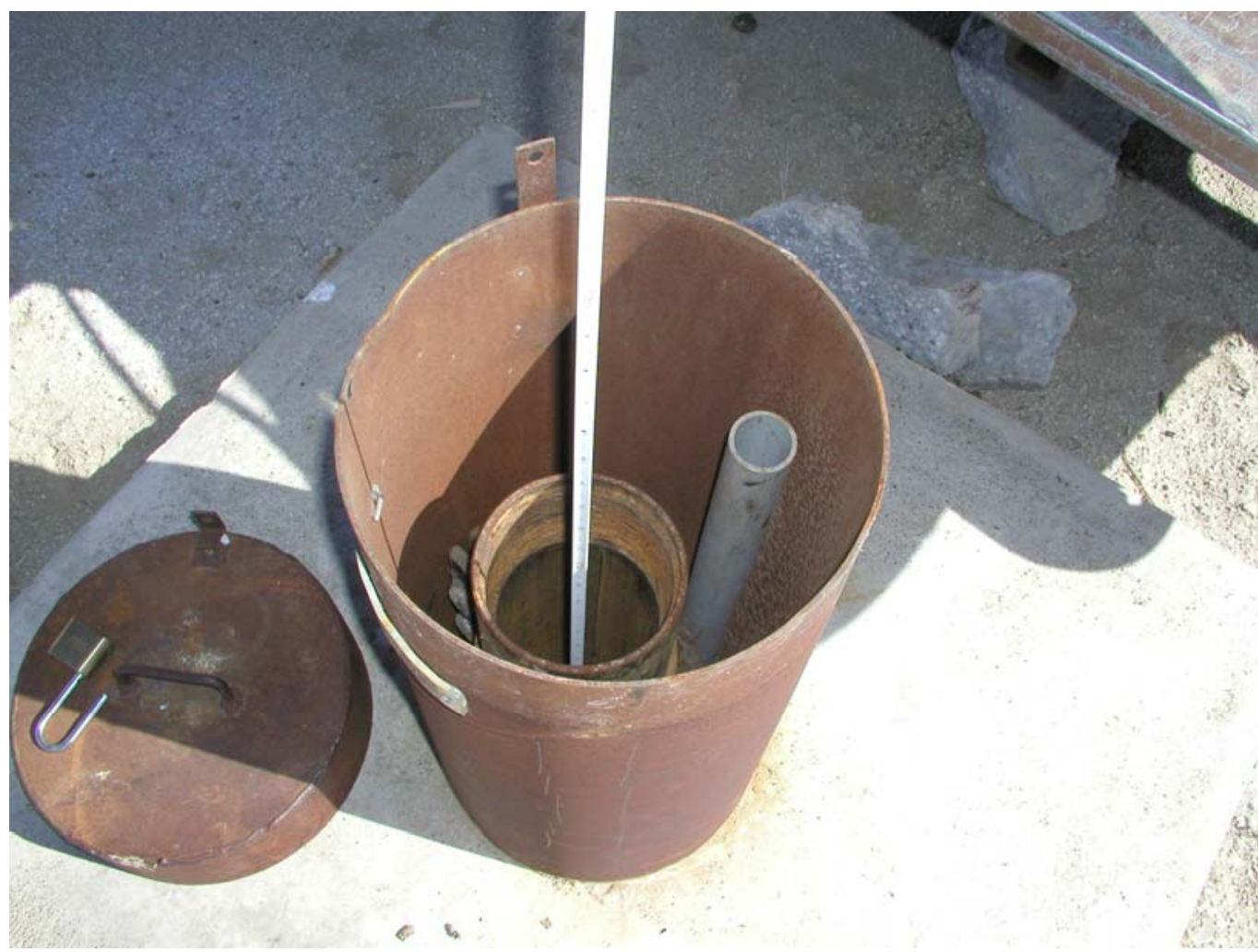

PSA HC-1 photograph top view (photograph taken 3/15/2004).

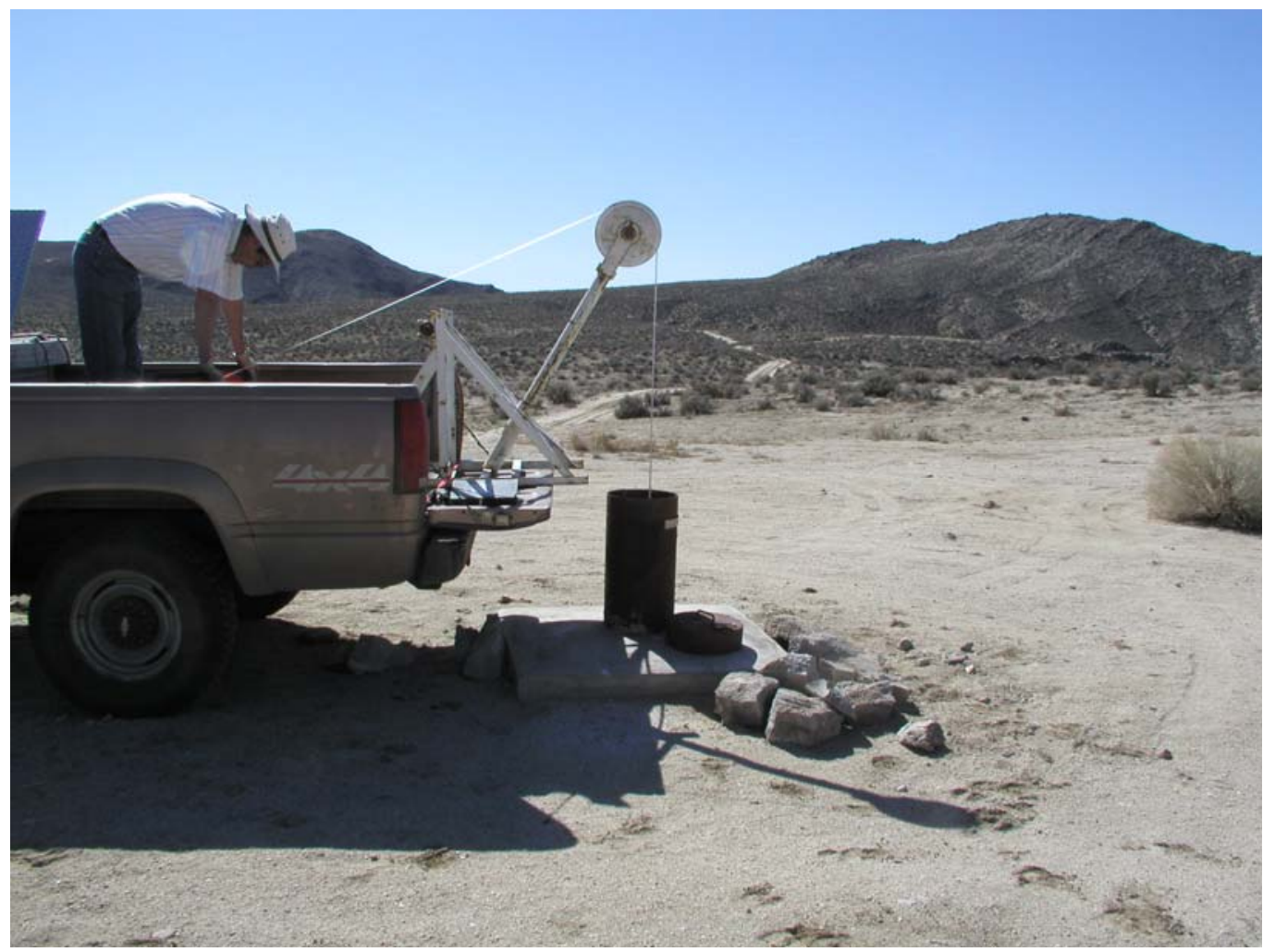

PSA HC-1 photograph side view while measuring water level (photograph taken 3/15/2004). 


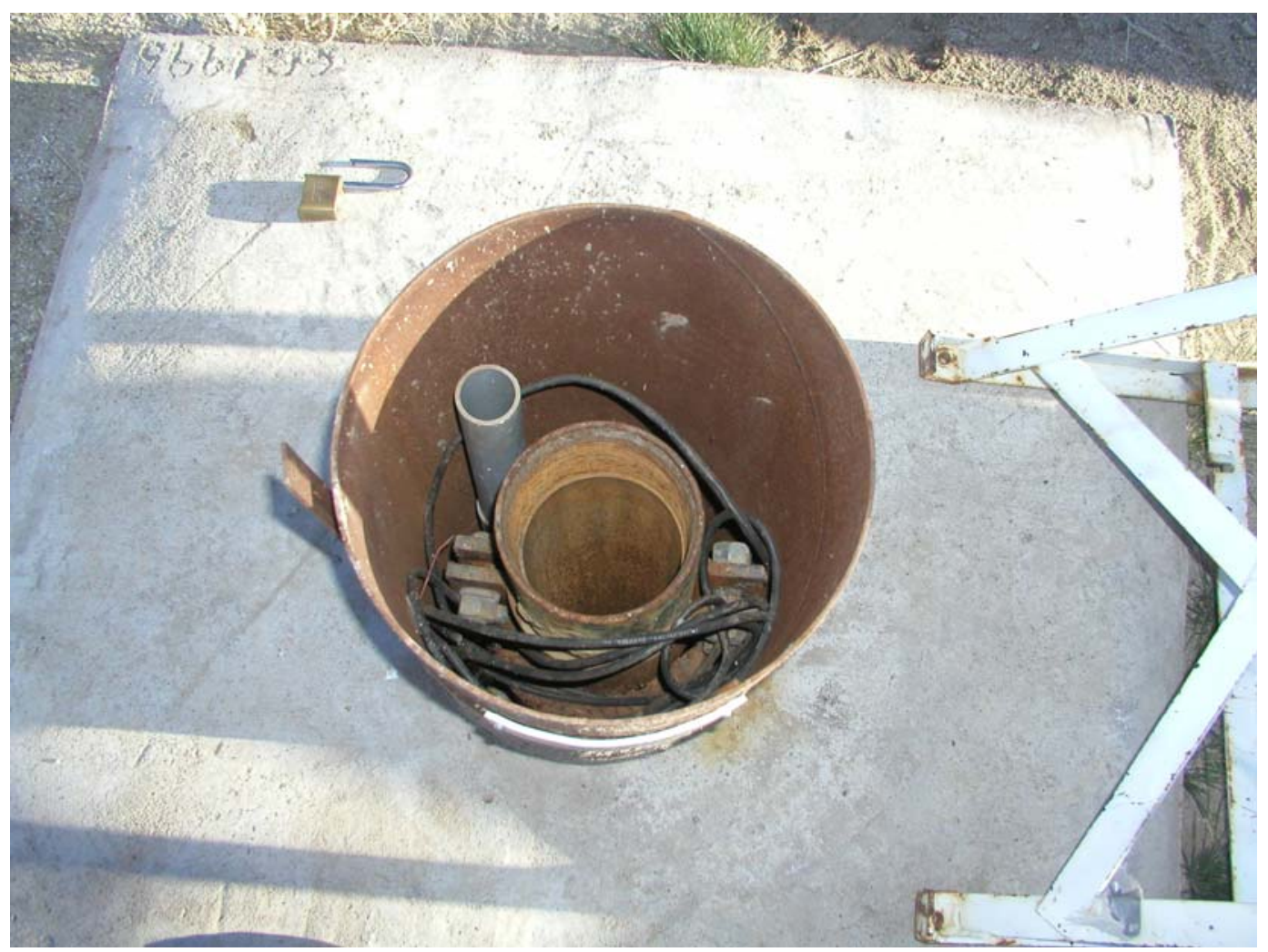

PSA HC-2 photograph top view (photograph taken 3/15/2004).

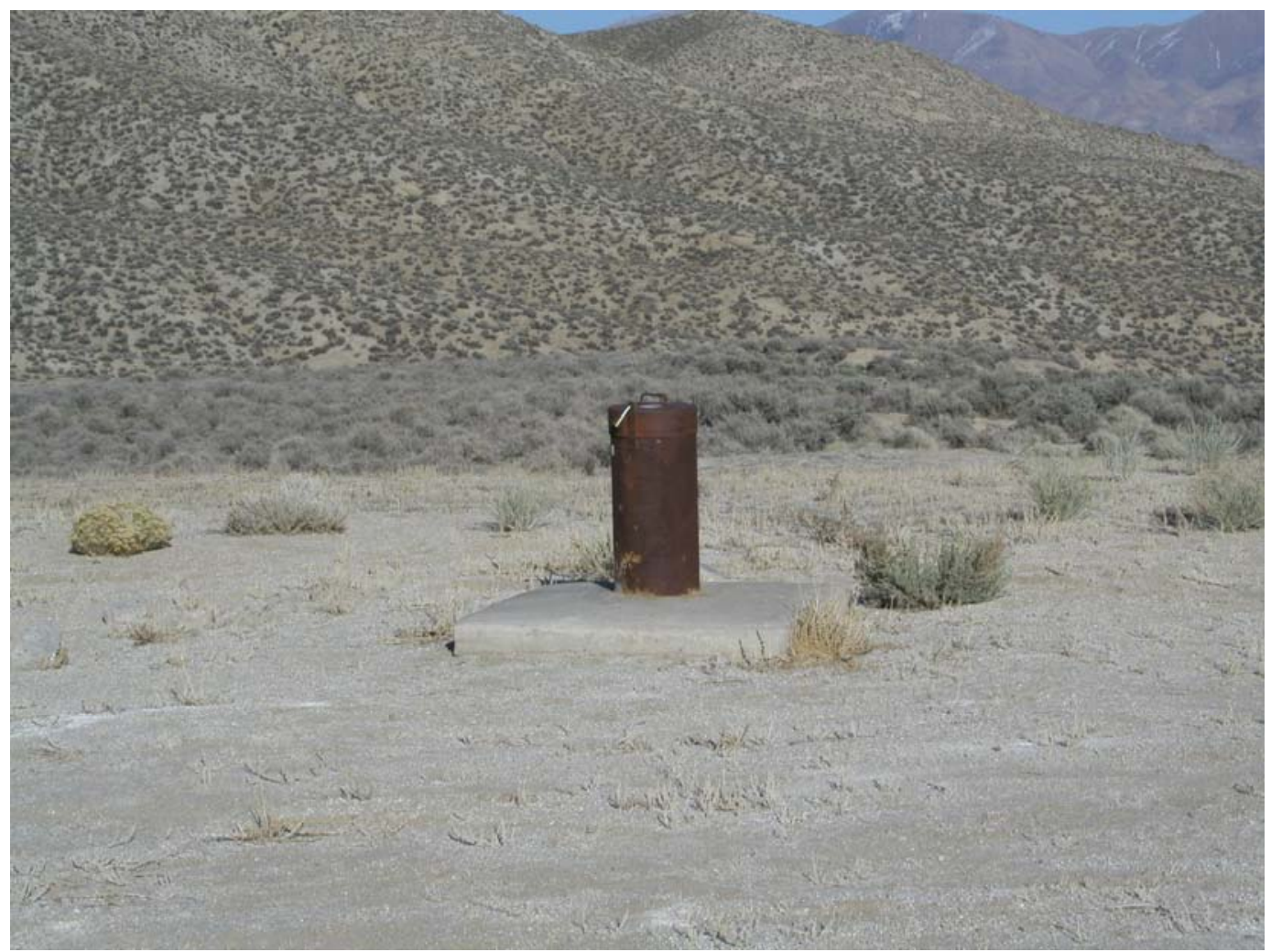

PSA HC-2 photograph side view (photograph taken 3/15/2004). 


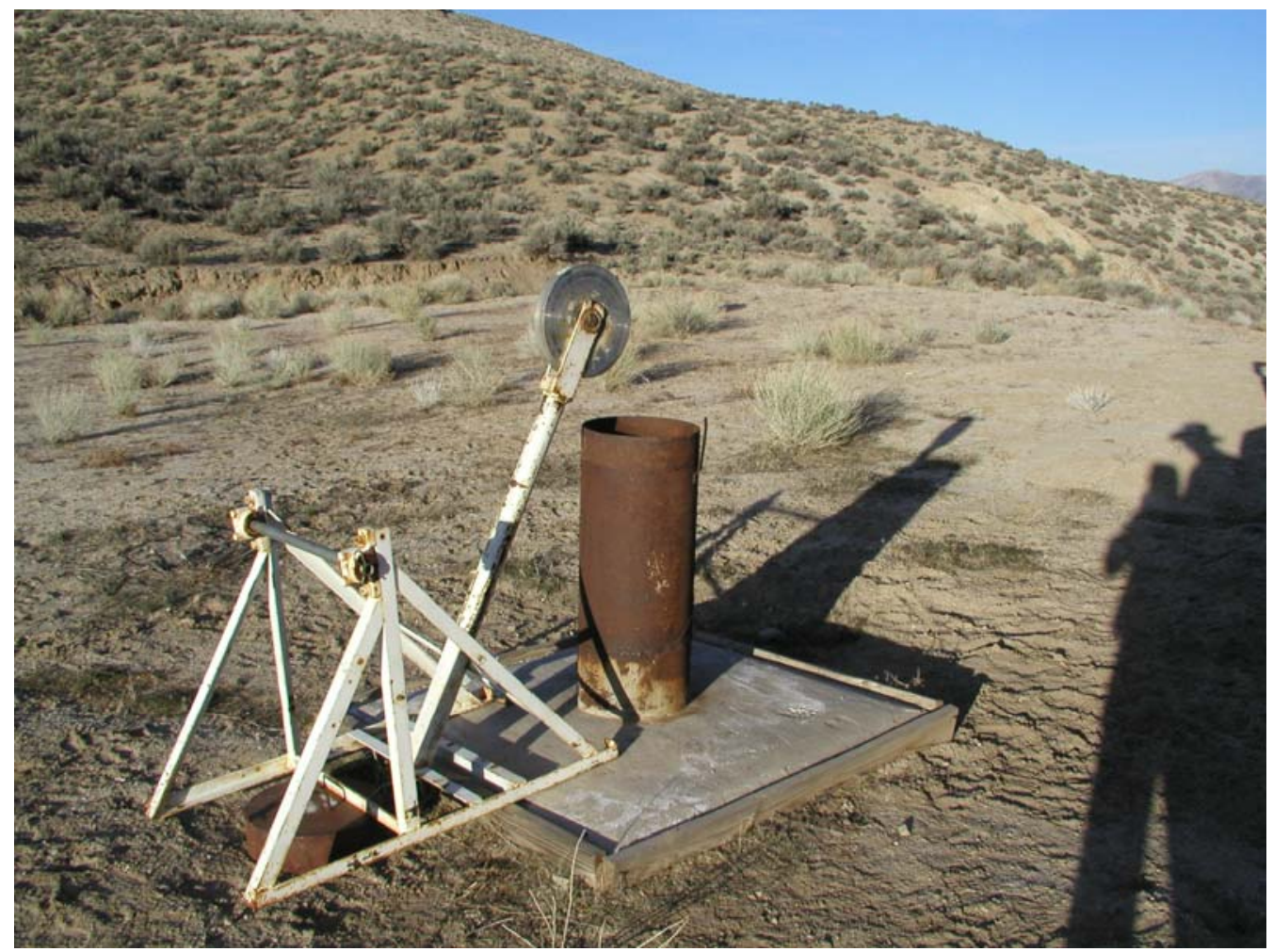

PSA HC-3 photograph side view while measuring water level (photograph taken 3/15/2004).

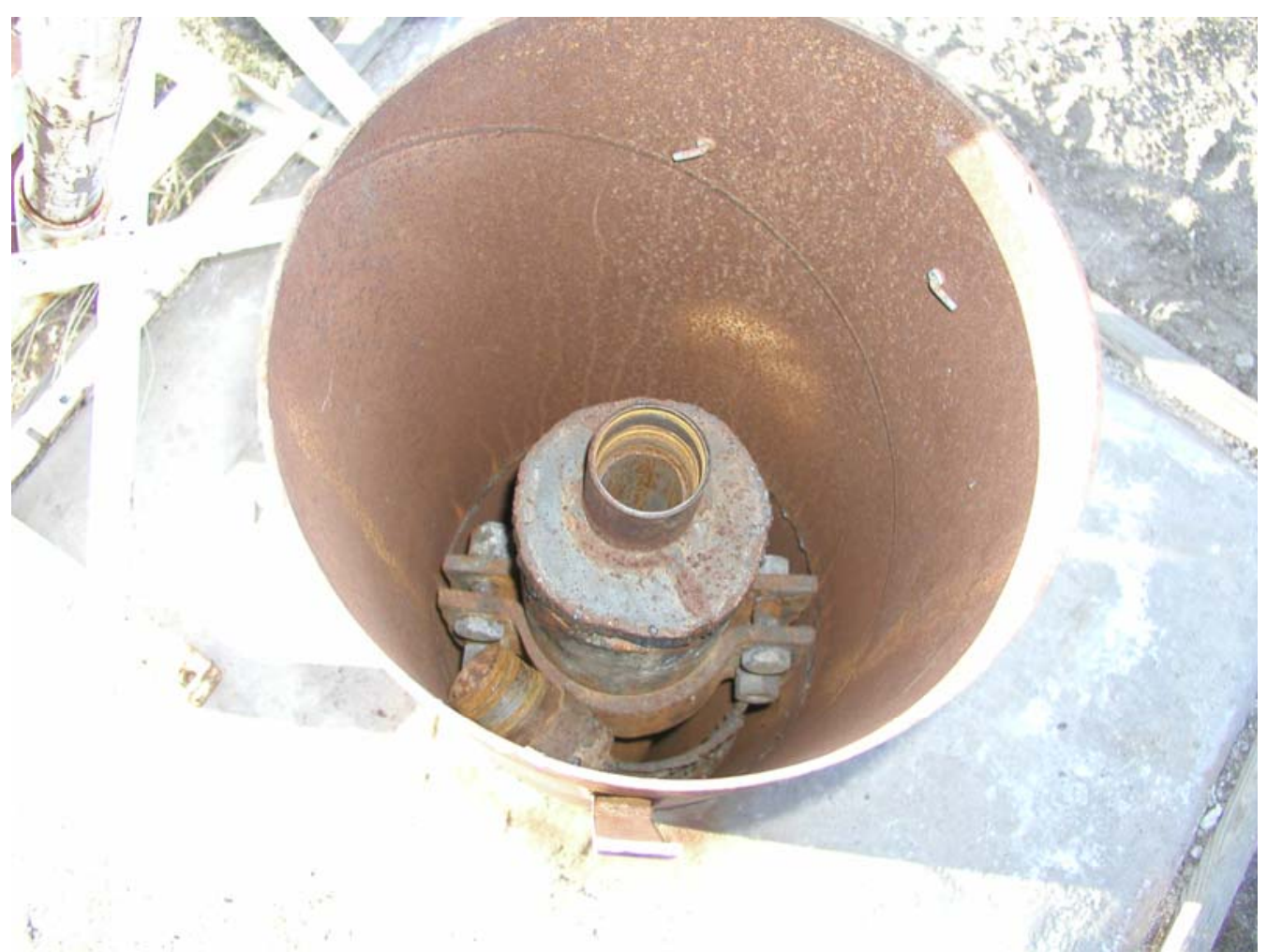

PSA HC-3 photograph top view (photograph taken 3/15/2004). 


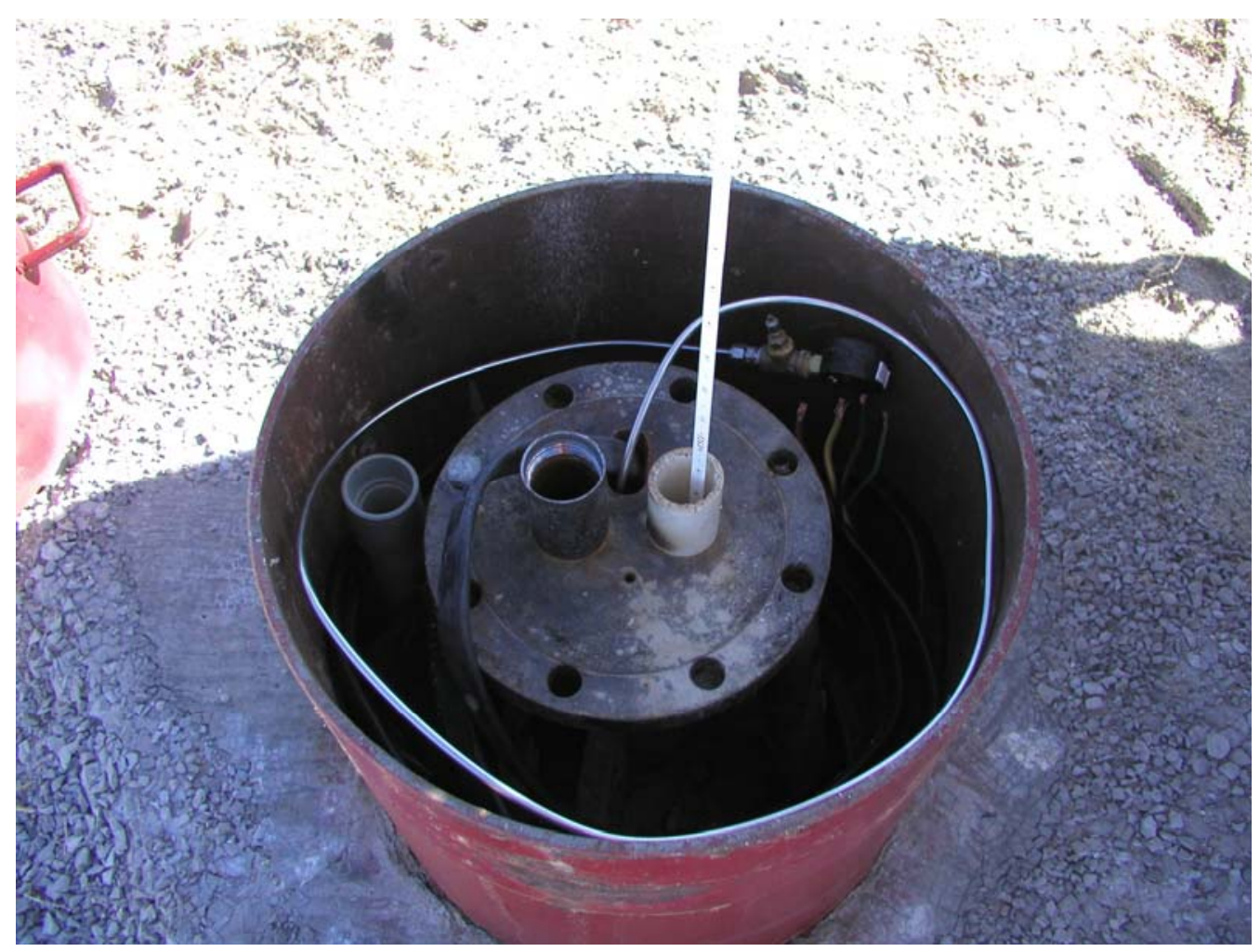

PSA HC-5 photograph top view (photograph taken 3/15/2004).

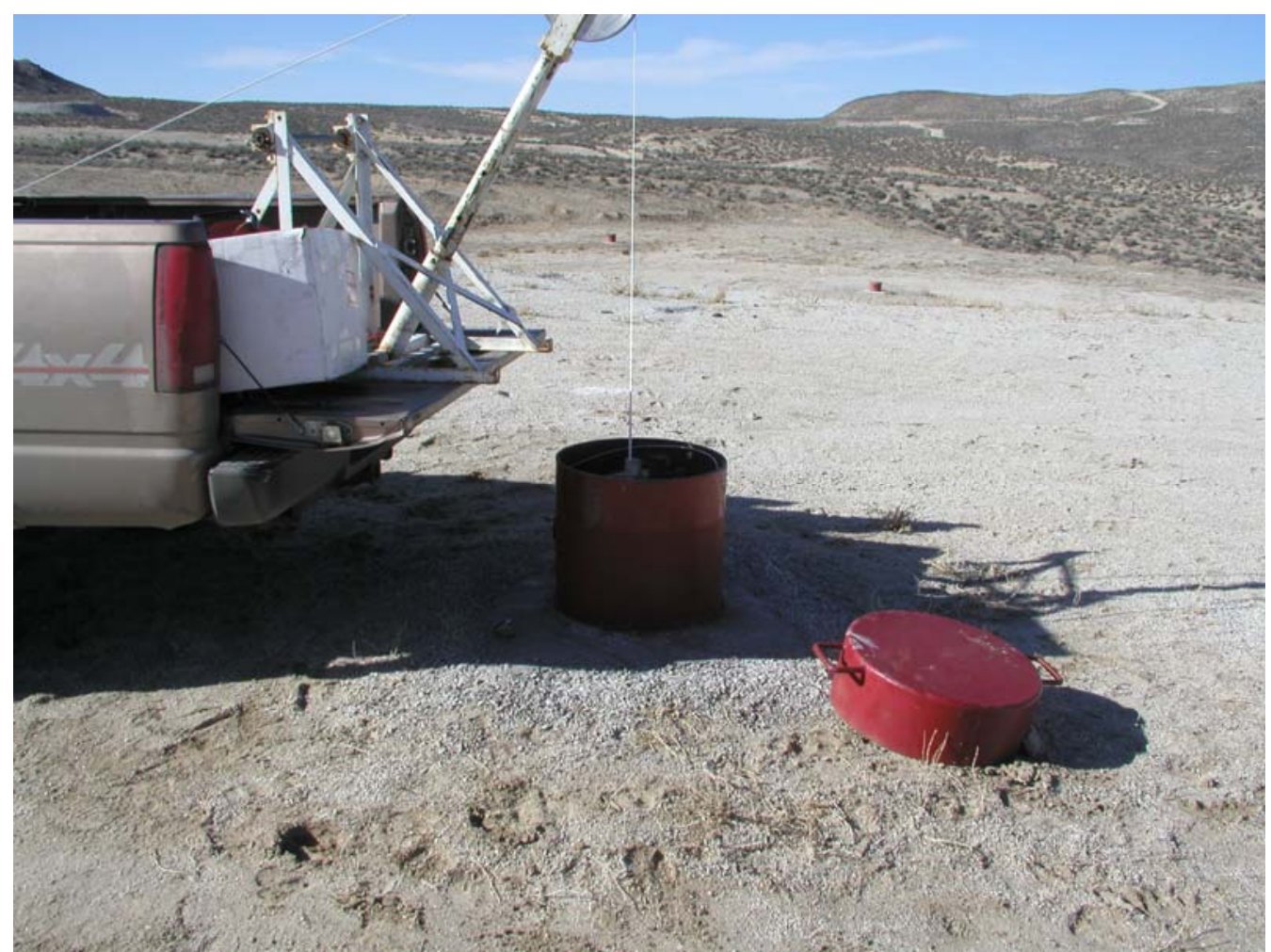

PSA HC-5 photograph side view while measuring water level (photograph taken 3/15/2004). 


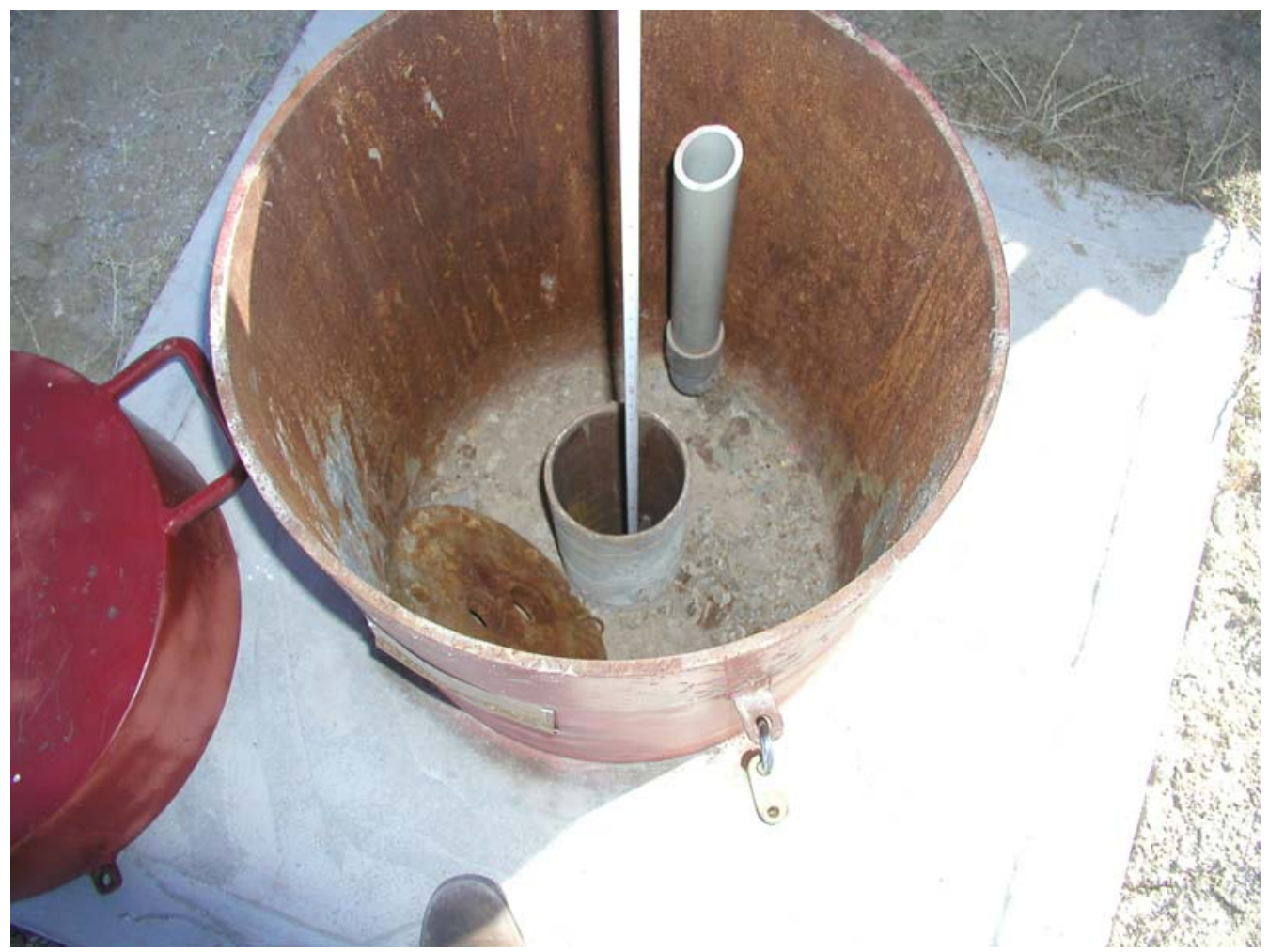

PSA HC-6 photograph top view (photograph taken 3/15/2004).

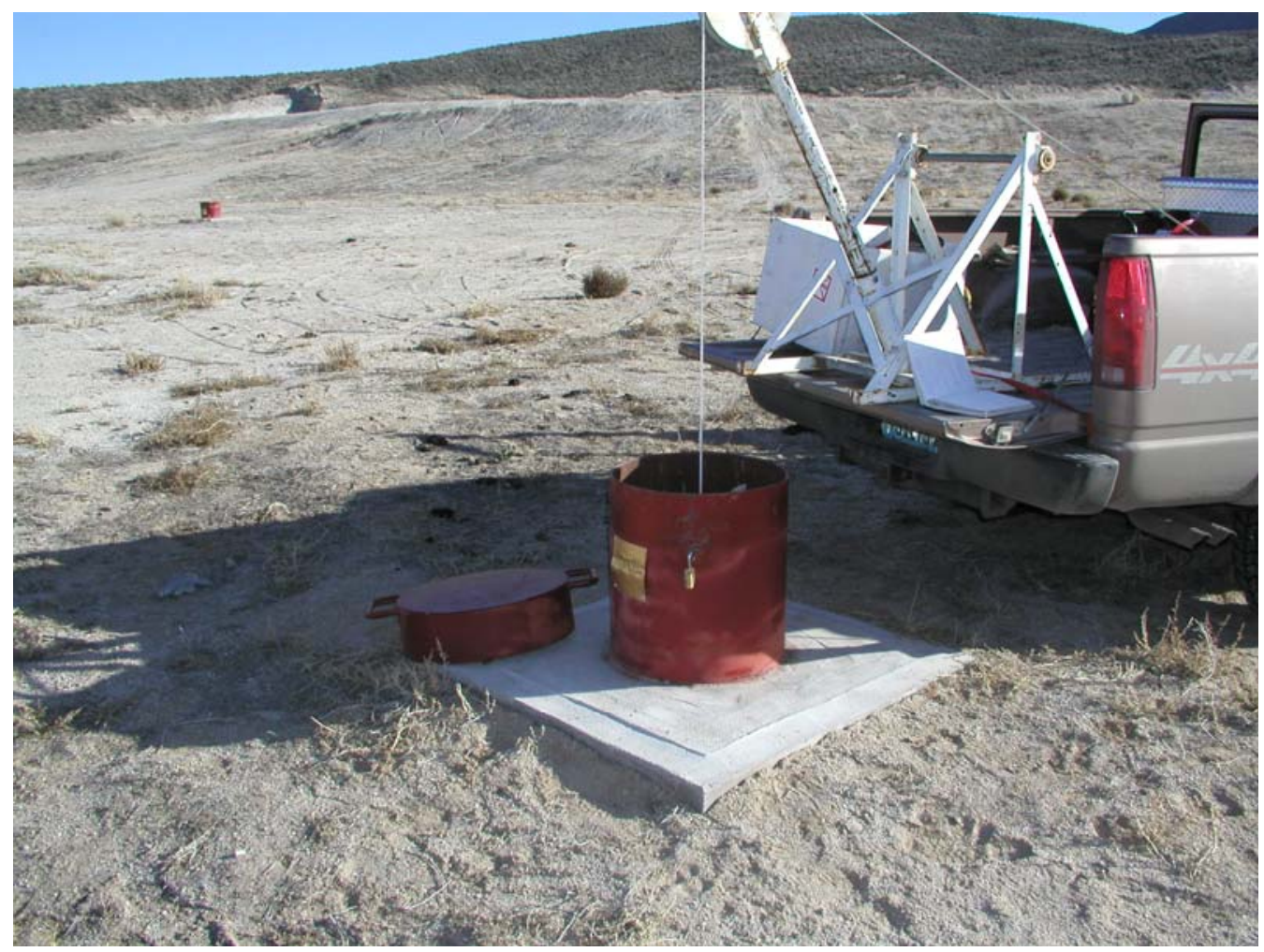

PSA HC-6 photograph side view while measuring water level (photograph taken 3/15/2004). 


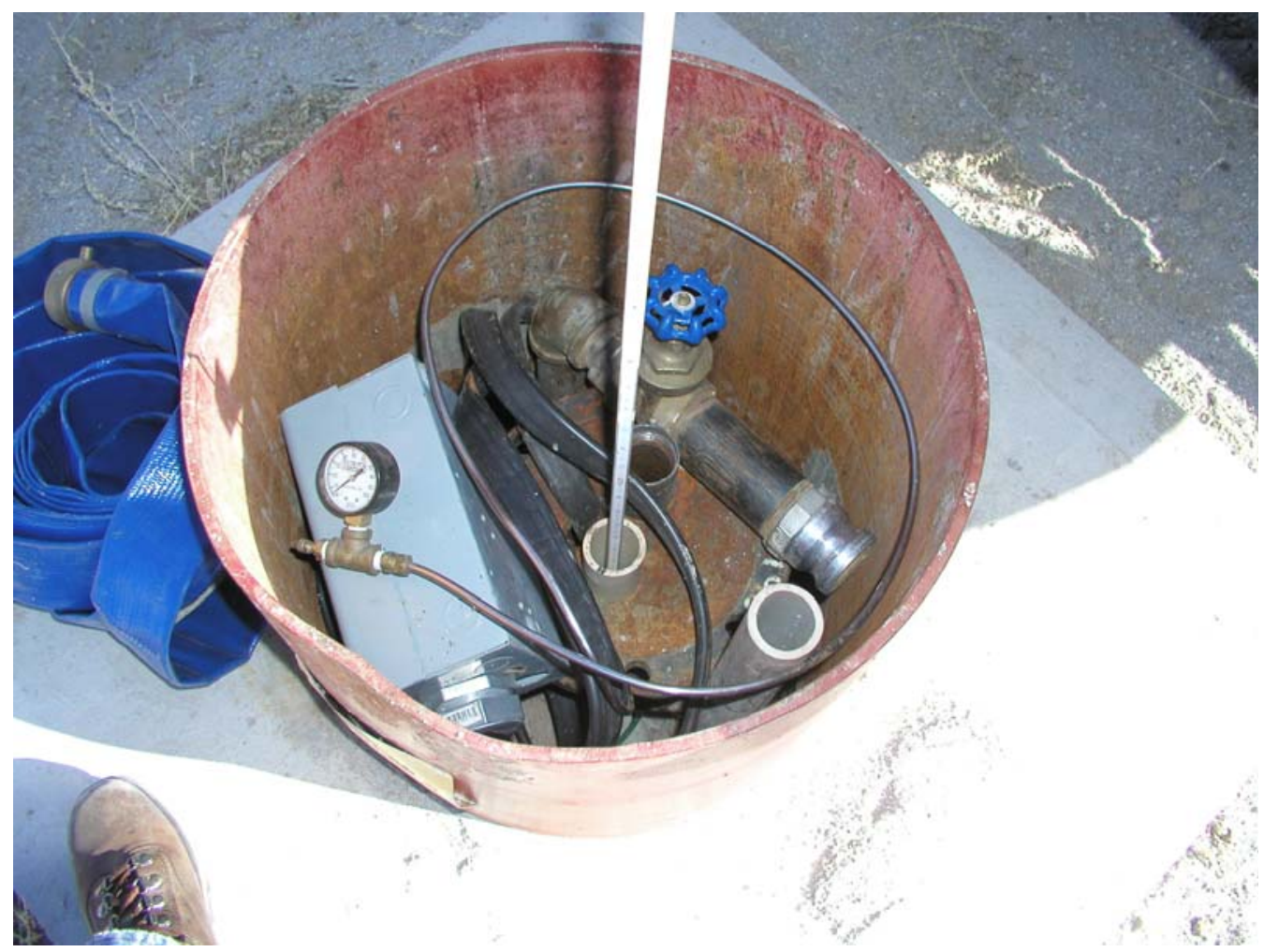

PSA HC-7 photograph top view (photograph taken 3/15/2004).

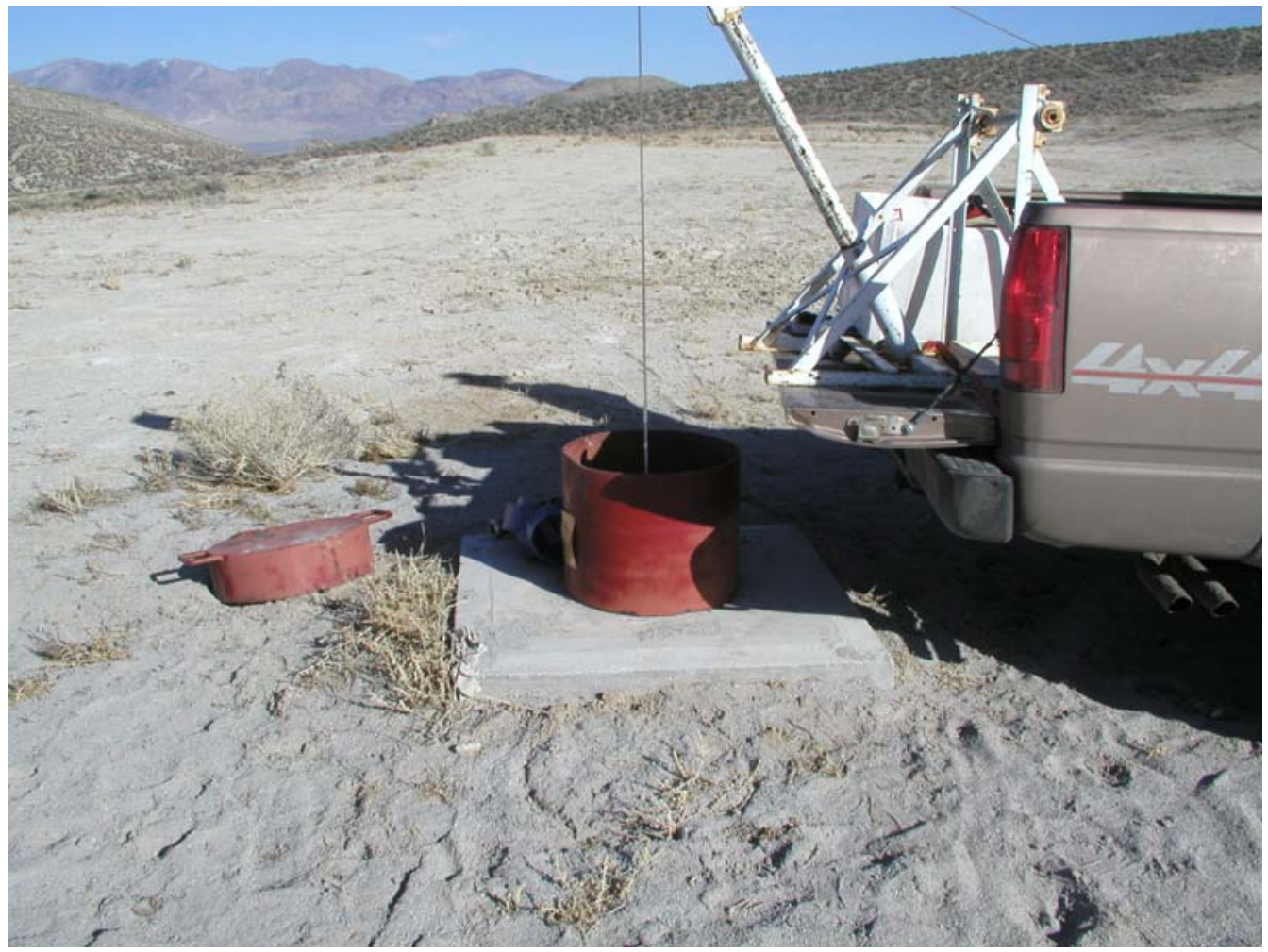

PSA HC-7 photograph side view while measuring water level (photograph taken 3/15/2004). 


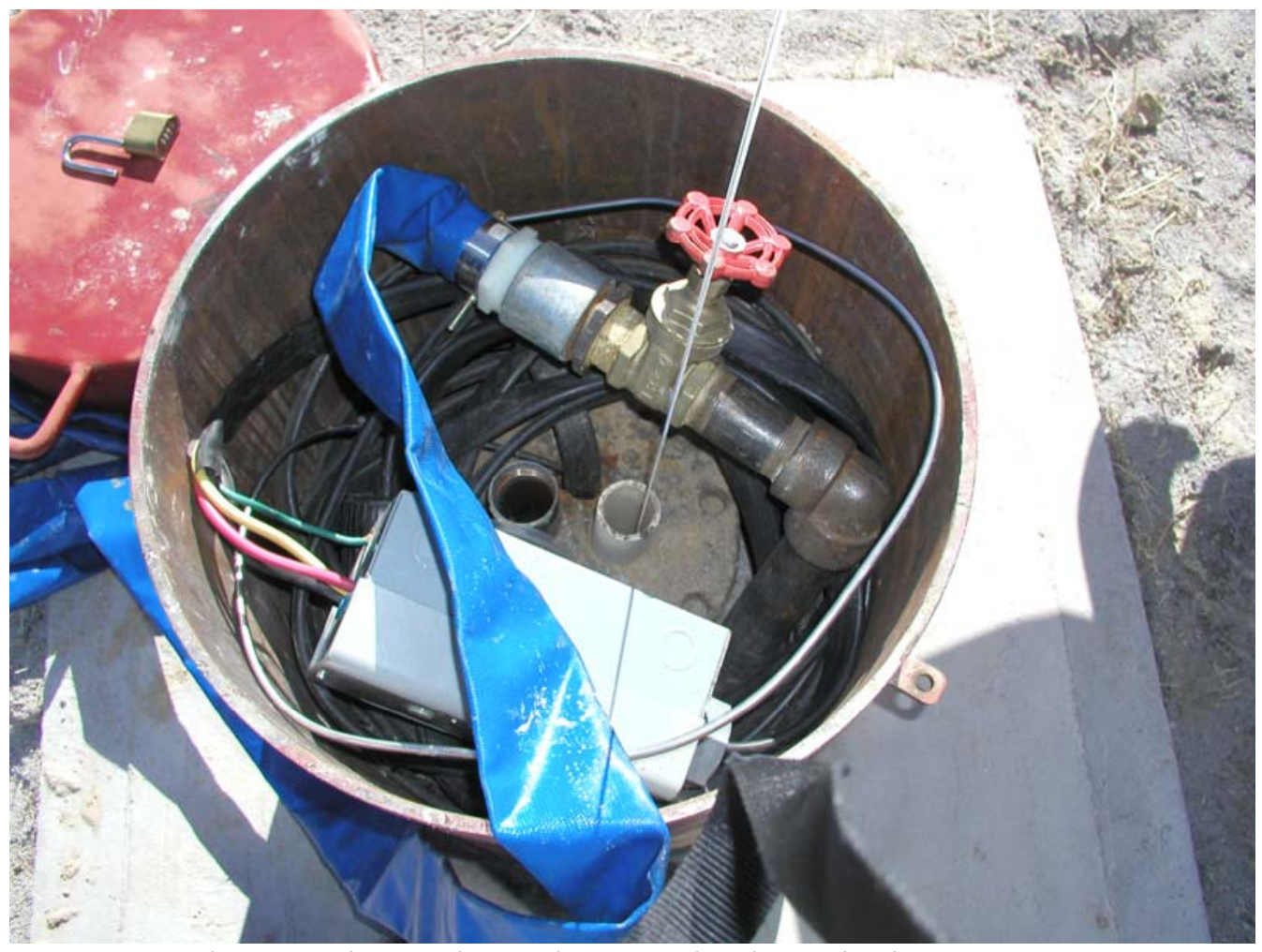

PSA HC-8 photograph top view (photograph taken 3/15/2004).

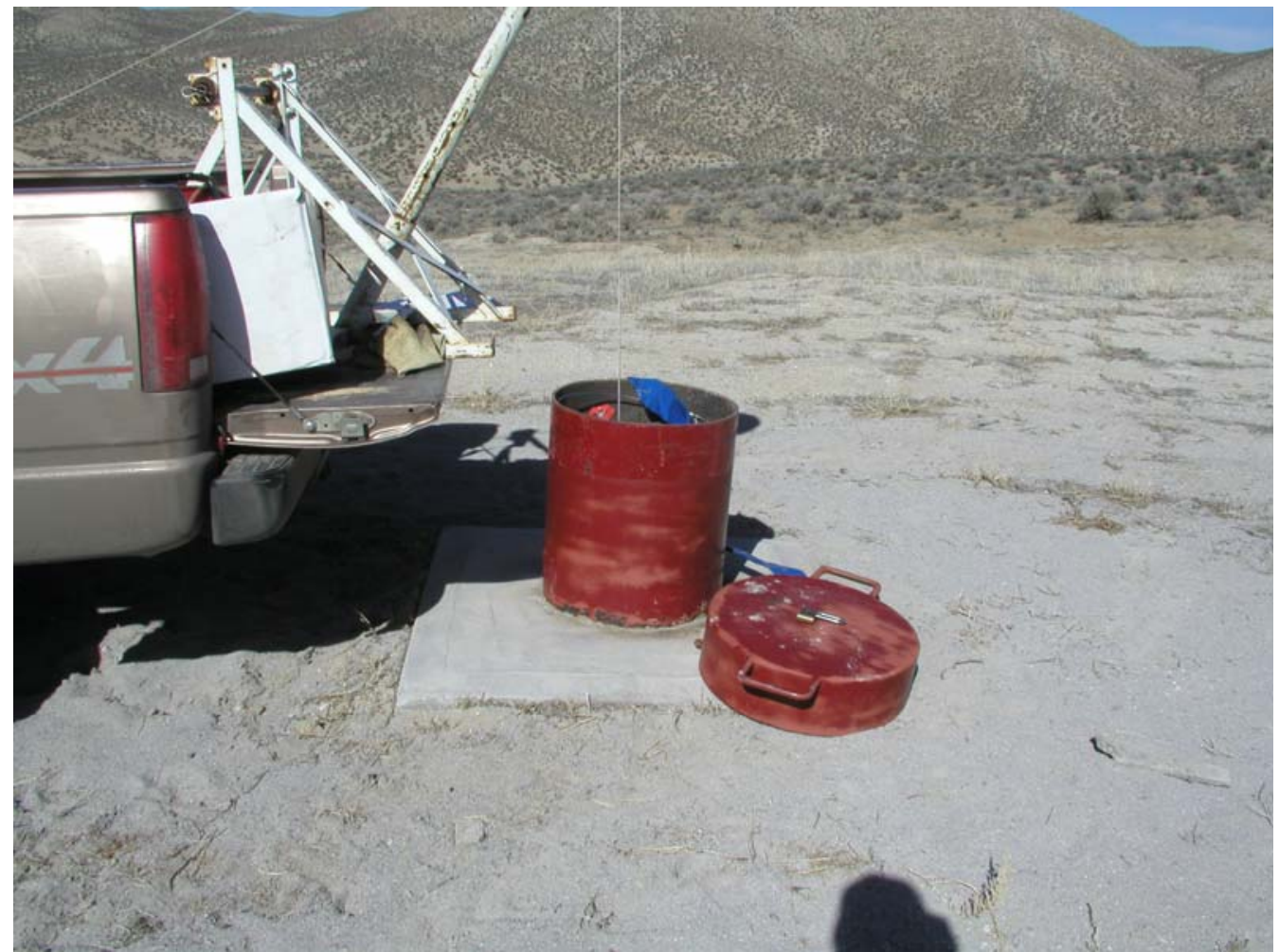

PSA HC-8 photograph side view while measuring water level (photograph taken 3/15/2004). 


\section{DISTRIBUTION}

Jenny Chapman

Division of Hydrologic Sciences

Desert Research Institute

755 East Flamingo Road

Las Vegas, NV 89119-7363

Tim Echelard

Stoller-Navarro Joint Venture

7710 W. Cheyenne

Las Vegas, NV 89128

Kenneth A. Hoar, Director

Environment, Safety and Health Division

Nevada Site Office

National Nuclear Security Administration

U.S. Department of Energy

P.O. Box 98518

Las Vegas, NV 89193-8518

Richard Hopper

Deputy Laboratory Director

U.S. Environmental Protection Agency

Radiation and Indoor Environments

National Laboratory

4220 S. Maryland Parkway, Bldg. C

Las Vegas, NV 89119

Bruce Hurley

Hydrology Program Manager

Environment, Safety and Health Division

Nevada Site Office

National Nuclear Security Administration

U.S. Department of Energy

P.O. Box 98518

Las Vegas, NV 89193-8518

Rick Hutton

Stoller Grand Junction

2597 B 3 / 4 Road

Grand Junction, CO 81503
John Jones

Environmental Restoration Division

Nevada Site Office

National Nuclear Security Administration

U.S. Department of Energy

P.O. Box 98518

Las Vegas, NV 89193-8518

Marjory Jones

Division of Hydrologic Sciences

Desert Research Institute

2215 Raggio Parkway

Reno, NV 89512-1095

Randy Laczniak

U.S. Geological Survey

Water Resources Division

160 N. Stephanie St.

Henderson, NV 89074-8829

Tom Pauling

Office of Land and Site Management

Office of Legacy Management

U.S. Department of Energy

25973 / 4 Road

Grand Junction, CO 81503

Peter Sanders

Environmental Restoration Division

Nevada Site Office

National Nuclear Security Administration

U.S. Department of Energy

P.O. Box 98518

Las Vegas, NV 89193-8518

Reina Serino, Contracting Specialist

Office of Business Services

NNSA Service Center

Pennsylvania and H Street, Bldg. 20388

P.O. Box 5400

Albuquerque, NM 87185-5400 
David Shafer

Division of Hydrologic Sciences

Desert Research Institute

755 E. Flamingo Road

Las Vegas, NV 89119-7363

Jacqueline Van Lier

Stoller-Navarro Joint Venture

7710 W. Cheyenne

Las Vegas, NV 89128

Janet Appenzeller-Wing, Director

Environmental Restoration Division

Nevada Site Office

National Nuclear Security Administration

U.S. Department of Energy

P.O. Box 98518

Las Vegas, NV 89193-8518

Nevada State Library and Archives

State Publications

100 North Stewart Street

Carson City, NV 89710-4285

Archives

Getchell Library

University of Nevada, Reno

DeLaMare Library/262

University of Nevada, Reno

Document Section, Library

University of Nevada, Las Vegas

4505 Maryland Parkway

Las Vegas, NV 89154
Library

Stoller-Navarro Joint Venture

7710 W. Cheyenne, Bldg. 3

Las Vegas, NV 89128

Library

Southern Nevada Science Center

Desert Research Institute

755 E. Flamingo Road

Las Vegas, NV 89119-7363

Technical Library

Nevada Site Office

National Nuclear Security Administration

U.S. Department of Energy

P.O. Box 98518

Las Vegas, NV 89193-8518

Public Reading Facility

c/o Nuclear Testing Archive

Nevada Site Office

National Nuclear Security Administration

U.S. Department of Energy

P.O. Box 98521, M/S 400

Las Vegas, NV 89193-8521

Office of Scientific and Technical Information

U.S. Department of Energy

P.O. Box 62

Oak Ridge, TN 37831-9939

(electronic copy) 